\title{
The Takings Clause: In Search of Underlying Principles Part II-Takings as Intentional Deprivations of Property Without Moral Justification
}

\author{
Andrea L. Peterson
}

\section{TABLE OF CONTENTS}

Introduction $\ldots \ldots \ldots \ldots \ldots \ldots \ldots \ldots \ldots \ldots \ldots \ldots \ldots \ldots \ldots \ldots, 56$

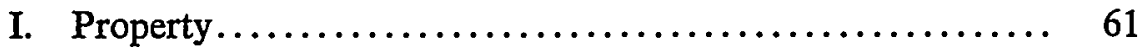

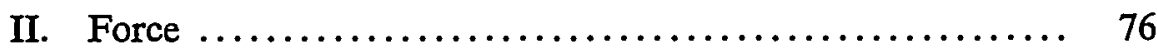

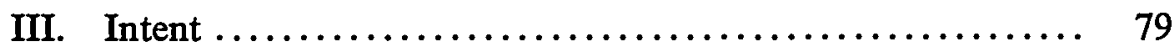

IV. Moral Justification .............................. 85

A. Overview .............................. 85

B. What Makes the Hard Cases Hard? ............... 93

C. Cases in Which the Governmental Decisionmakers

Did Not Purport to Be Making a Judgment of

Wrongdoing............................... 96

D. Reviewing Purported Judgments of Wrongdoing...... 98

E. Preventing Harm Versus Preventing or Punishing Wrongdoing............................. 106

F. Variation in Moral Judgments Temporally and Geographically ............................. 110

G. Generalized Moral Judgments ................ 115

H. Facial and As Applied Takings Challenges ......... 120

I. Governmental Commitments.................. 123

1. Takings Clause Cases Involving Governmental Commitinents ......................... 123

2. The Relationship Between Contract Clause Cases Involving Governmental Commitınents and Takings Clause Cases Involving Governmental Commitments ........................... 128

J. Civic Obligations ........................... 131

K. Re-exarnining the Cases in Light of the Moral Justification Principle ......................... 140

1. Takings Clause Decisions .................. 140 
[Vol. 78:53

2. Substantive Due Process Cases Involving the Government's Broad Power to Regulate to Promote the Common Good ........................ 148

V. Where Has the Court Gone Wrong? ................ 153

Conclusion $\ldots \ldots \ldots \ldots \ldots \ldots \ldots \ldots \ldots \ldots \ldots \ldots \ldots \ldots \ldots \ldots, 161$ 


\title{
The Takings Clause: In Search of Underlying Principles Part II-Takings as Intentional Deprivations of Property Without Moral Justification $\dagger$
}

\author{
Andrea L. Peterson ††
}

In this Article, Professor Peterson offers a theory of the takings clause that explains when the Supreme Court will find that a compensable taking of property has occurred. In constructing this theory, she sought to account not only for the results in the great majority of the Court's takings decisions, but also for many generally accepted propositions regarding when a governmental deprivation of property constitutes a compensable taking. She offers a single set of principles that apply regardless of whether the challenged governmental action is regulation, physical action, or a formal exercise of the government's eminent domain power. Professor Peterson argues that the Court finds a compensable taking when the government intentionally forces the claimant to give up her property, unless the lawmakers are seeking to prevent or punish action (or failure to act) by the claimant that they reasonably believe the public would consider wrongful. Professor Peterson does not suggest that these principles suddenly make the difficult takings cases easy to decide. Rather, she offers these principles to show why some takings cases are relatively easy to decide and others are far more difficult, and to provide a coherent framework for analyzing future takings cases.

"[T]his Court, quite simply, has been unable to develop any 'set formula'

Copyright () 1990 by Andrea L. Peterson. All rights reserved.

$\dagger$ The first Article, The Takings Clause: In Search of Underlying Principles, Part I-A

Critique of Current Takings Clause Doctrine, appeared at 77 CALIF. L. REv. 1299 (1989).

t† Acting Professor of Law, Boalt Hall School of Law, University of California, Berkeley. A.B. 1974, Stanford University; J.D. 1978, Boalt Hall School of Law, University of California Berkeley.

I would like to thank the many colleagues who provided helpful comments on this Article, including Jesse Choper, Jack Coons, Willy Fletcher, Jim Gordley, Paul Mishkin, Robert Post, Dan Rubinfeld, Joe Sax, Martin Shapiro, Mike Smith, Larry Sullivan, Jan Vetter, and Jeremy Waldron. I owe special thanks to Michael Rubin, Steve Bundy, and Paul Kahn, who offered unflagging support and many thoughtful suggestions. Thanks also to the participants in the Duke University School of Law faculty colloquium, particularly Chris Schroeder and Kate Bartlett. Finally, I greatly appreciated the assistance of Mike Miller of the California Law Review, and of my research assistants, Susan Huber, Steve Holtzman, Eric Esler, Jim Smith, and Bill McElyea. 
for determining when 'justice and fairness' require that econonic injuries caused by public action be conıensated by the government ...."1

“[T]he attenipt to differentiate 'regulation' from 'taking' [has been characterized] as 'the most haunting jurisprudential problem in the field of contemporary land-use law . . . one that may be the lawyer's equivalent of the physicist's hunt for the quark.' "2

\section{INTRODUCTION}

One of the most intractable and significant probleins facing the Supreine Court today is the task of determining when governinental action that causes econo1nic injury to private parties constitutes a compensable "taking" under the takings clause of the fifth amendment. ${ }^{3}$ The Court has atteinpted on nuinerous occasions during the past decade to articulate when a taking occurs. Yet, as shown in Part I of this Article, the inore effort the Court has devoted to the issue, the more confused and complex its takings doctrine has becoine. ${ }^{4}$

The Court has repeatedly stated that the takings clause prevents the government from "forcing soine people alone to bear public burdens which, in all fairness and justice, should be borne by the public as a whole." "s Yet the Court has made hittle effort to develop a principled basis for determining when fairness requires the payinent of compensation. Instead, the Court has employed four different tests in its recent takings decisions to deternine whether regulation or physical action by the government effects a taking. ${ }^{6}$ Sometimes the Court has applied the three-factor Penn Central test, in which the Court considers the character of the governmental action, the extent to which the government has interfered with reasonable, investment-backed expectations, and the

1. Penn Cent. Transp. Co. v. New York City, 438 U.S. 104, 124 (1978).

2. San Diego Gas \& Elec. Co. v. City of San Diego, 450 U.S. 621,649 n. 15 (1981) (Brennan, J., dissenting) (quoting C. HAAR, LAND-USE PLANNING 766 (3d ed. 1976)).

3. The takings clause provides that "private property [shall not] be taken for public use, without just compensation." U.S. CONST. amend. V. The takings clause is applied to the states through the due process clause of the fourteenth amendment. See Chicago, B. \& Q.R.R. v. Chicago, 166 U.S. 226 (1897).

4. See Peterson, The Takings Clause: In Search of Underlying Principles, Part I-A Critigue of Current Takings Clause Doctrine, 77 CALIF. L. REV. 1299 (1989) [hereinafter Peterson I]. (1960)).

5. Penn Central, 438 U.S. at 123 (quoting Armstrong v. United States, 364 U.S. 40,49

6. There is no dispute that a taking occurs when the government formally exercises its power of eminent domain. If, for example, the government condemns $A$ 's land to use it as a site for a public park, a taking has clearly occurred. The controversial issue is when regulation or physical action by the government effects a taking. For example, $A$ might claim that a taking occurred if the government prohibited her from building on her land, as in First English Evangelical Lutheran Church v. County of Los Angeles, 482 U.S. 304 (1987), or if it flooded her land, as in Pumpelly v. Green Bay Co., 80 U.S. (13 Wall.) 166 (1871). 
severity of the economic impact on the claimant. ${ }^{7}$ At other times, the Court has relied on the two-part Agins test, which provides that a taking occurs if a land-use regulation either does not substantially advance legitimate state interests or denies an owner all economically viable use of his land. ${ }^{8}$ In other cases, the Court has ignored the first part of the Agins test, asking only whetlier tlie cliallenged law denies landowners all economically viable use of their land. ${ }^{9}$ In still other cases, the Court has applied the per se rule almounced in Loretto v. Teleprompter Manhattan $C A T V$ Corp., ${ }^{10}$ that any permanent physical occupation authorized by government constitutes a taking. ${ }^{11}$ It is difficult to predict which test, or combination of tests, the Court will apply in any particular takings case. ${ }^{12}$ Moreover, as shown in Part I of this Article, the Court has not interpreted any of these tests in a consistent maimer. ${ }^{13}$

To coinplicate matters further, the Court has offered conflicting definitions of "property" in its takings decisions. ${ }^{14}$ At times, tlie Court has equated "property" witlı a tangible thing, such as a parcel of land. ${ }^{15}$ At other times, it lias concluded that property for takings clause purposes consists of economically valuable legal riglits. ${ }^{16}$ In yet other instances, the Court has suggested that economically valuable legal rights constitute "property" only if they are "vested," meaning that the lawmakers have not reserved the power to cliange the law in a manner that modifies or eliminates the rights. ${ }^{17}$

Given this state of affairs, one could easily conclude that the Supreme Court's takings jurisprudence is in coinplete disarray. As a

7. The Court first announced this test in Penn Central, 438 U.S. at 124.

8. Agins v. City of Tiburon, 447 U.S. 255, 260 (1980).

9. See, e.g., Hodel v. Virginia Surface Mining \& Reclamation Ass'n, 452 U.S. 264 (1981).

10. 458 U.S. 419 (1982).

11. Id. at 441 .

12. For example, the Court has said that when a land-use regulation is challenged "on its face," the test for a taking is whether the law deprives landowners of all economically viable use of their land, but if the law is challenged "as applied," the three-factor Penn Central test should be used. Yet at times the Court applies the "no economically viable use" test to "as applied" challenges, and at times it applies the Penn Central test to facial challenges. See Peterson I, supra note 4 , at $1360-61$.

The Court has also said that any "permanent" physical oceupation constitutes a taking, but it is difficult to know when the Court will consider a physical invasion to be "permanent." For example, in Loretto the Court characterized an "easement of passage" as a temporary physical invasion, 458 U.S. at 433, but in Nollan v. California Coastal Commission, 483 U.S. 825, 831-32 (1987), the Court characterized a similar easement as a permanent physical oceupation.

13. See Peterson I, supra note 4.

14. The definition of the relevant unit of "property" is critical in a takings ease, since obviously no "taking" can occur uuless the government has deprived the claimant of property.

15. In such eases, the Court generally has defined the relevant unit of property as the "parcel as a whole." See Peterson I, supra note 4, at 1308-09.

16. Id. at $1310-12$.

17. Id. at 1313-14. 
doctrinal matter, that is true. Given the current state of the doctrine, it is virtually impossible to predict how the Court will explain a takings decision. ${ }^{18}$ But despite this chaos, there seems to be a general pattern to the results reached by the Court in its takings decisions. One can often predict how the Court will ultimately rule in a takings case, or at least whether the case will be a close one. ${ }^{19}$ Moreover, in many cases in which the government has forced a private party to give up an econounically valuable resource, a takings claim is not even raised, because there is widespread agreeinent that no compensable "taking" has occurred. For exainple, it is generally assumed that no taking occurs when the government requires $A$ to pay a fine, to forfeit soinething used in the commission of a crime, or to pay damages for coinmitting a tort or breaching a contract. There is also widespread agreeinent that a taking does occur when the government condemns $A$ 's land as a site for a public park or a highway. Thus, it is unuch easier to predict when the Court will find a taking than one would anticipate, given the state of the Court's current takings doctrine.

This predictability suggests that an unarticulated pattern underlies the Supreine Court's takings jurisprudence. In this Article, I attempt to identify a set of principles that account for and explicate that underlying pattern. My task is descriptive, not normative, in that I do not ask when the government should be required to coinpensate private parties for econoimic imjuries caused by government action. ${ }^{20}$ Rather, I attempt to articulate primciples that can be used to explam the results in the great majority of the Court's takings decisions and to account for many generally accepted propositions as to when a taking occurs.

I began looking for a single set of principles that would explain when the Court will find a coinpensable taking, regardless of whether the challenged governmental action is regulation, physical action, or a formal exercise of the governinent's emment doinam power. The notion that the takings cases might be explained through a unified set of principles seemed plausible to me for a number of reasons. First, the fact that one can so often predict whether the Court will (or at least would be likely to) find a taking suggested that a simgle coherent set of principles

18. Part I illustrates this point using Nollan v. California Coastal Commission, 483 U.S. 825 (1987). See Peterson I, supra note 4, at 1335-41.

19. See Peterson I, supra note 4, at 1341-42.

20. One could, however, say that my task is nornative in the sense that $I$ attempt to articulate a coherent set of principles that explain the takings cases. Moreover, I recognize that the descriptive task of articulating prineiples that account for the results in the Court's takings decision interacts to some extent with the normative question of how the takings cases should be decided. When searching for principles that might account for a given body of case law, one inevitably begins by trying out theories that seem at least plausible from a normative point of view. 
might underlie the Court's takings decisions. ${ }^{21}$ Second, I could see no principled basis for defining a "taking" of "property" differently depending on whether the governinental action at issue was regulation, physical action, or an exercise of the eminent domain power. Third, the Supreme Court itself often assumes that a unified set of principles should be applied to determine whether a taking occurs in each of these contexts. ${ }^{22}$

In Part I of this Article, I reviewed the Court's various definitions of property and its various tests for determining whether a deprivation of property constitutes a compensable taking. I concluded that although the Court's current doctrine is in chaos, certain elements of the Court's current doctrine might be used as the basis for constructing a coherent account of when a taking occurs. ${ }^{23}$ Building on that analysis, $I$ argue in Part II that the Court's takings decisions can best be explained by saying that a compensable taking occurs whenever the government intentionally forces $A$ to give up her property, uuless the government is seeking to prevent or punish wrongdoing by $A$.

To account for the wide range of cases in which the Court has exphicitly or imphicitly concluded that property was at issue, I einploy a broad, two-part definition of property. First, $A$ 's "property" consists of her freedom to act in ways that are economically valuable to her, regardless of whether the government has granted this freedoin to $A$ as a matter of positive law. Second, $A$ acquires "property" when the government grants $A$ a legal right to force $B$ or the government to act in ways that are economically valuable to her. ${ }^{24}$

A taking can ouly occur if the government forcibly deprives $A$ of her property. The government might force $A$ to give up her property through a formal eminent domain proceeding or by enacting a law or taking physical action that requires $A$ to give up her property. Disagreement as to whether a case involves a forced transfer or a voluntary exchange of property often stems from uncertainty about what constitutes $A$ 's property. ${ }^{25}$

21. One might respond that the results in the Court's takings cases could be predictable even if they could not be explained by a unified set of principles. One principle might govern cases involving regulation, for example, and another quite unrelated principle might govern cases involving physical invasions. My sense, however, is that the underlying pattern does not depend on the type of governmental action at issue. For example, we would agree that a taking occurs whether the government fornally condemns $A$ 's land to use it as a public park or simply zones it for public park use only.

22. These points are discussed more fully in Part I of this Article. See Peterson I, supra note 4, at $1342-44$.

23. Id. at $1344-62$.

24. The government inay, however, reserve the power to change the law in a manner that alters such a right. No taking occurs if the government is acting witlim the scope of its reserved power. See infra text accompanying notes 62-68.

25. This point is illustrated by cases involving development exactions and incentive zoning laws. See infra text accompanying notes 123-24. 
No taking can occur unless the government intentionally deprives $A$ of her property. The intent requirement is satisfied if the government affirmatively desired to deprive $A$ of her property, or if the government knew or should have known that its actions would be substantially certain to deprive $A$ of her property. The intent requirement explains why some governmental actions that result in the deprivation of $A$ 's property are considered mere torts, while others are considered takings. ${ }^{26}$

Even if the government forcibly and intentionally deprives $A$ of her property, no compensable taking occurs if the government is merely preventing or punishing wrongdoing by $A$. If the government requires $A$ to give up property because it would be wrong of her not to do so, fairness does not require that compensation be paid. Nor does fairness require payment of compensation if the government requires $A$ to give up her property to punish her for a wrongful act. Compensation must be paid, however, if the government's only justification for forcing $A$ to give up her property is to promote the common good. ${ }^{27}$

Although I did not conceive of this Article as a response to Richard Epstein's book, Takings, ${ }^{28}$ readers will undoubtedly find it useful to contrast Epstein's views with the principles articulated here. ${ }^{29}$ While Epstein contends that his theory is correct in principle, he readily acknowledges that it "invalidates much of the twentieth-century legislation." 30 In contrast, my theory offers a coherent framework for analyzing future takings cases im a manner that is consistent with both existing case law and generally accepted propositions as to when a taking occurs. Epstem has commented that his critics, despite their vehement objections to his theory, have "develop[ed] no substantive account of their own, because they have no central theorem, normative or descriptive, on which to base such an enterprise. ... [It] takes a theory to beat a theory, and ... Takings [offers] 'a complete theory of the takings clause, and the only such theory around." "31 While I do not offer a normative theory of

26. The intent requirement also helps to resolve the controversy as to whether frequent low flights by government planes that interfere with the use of $A$ 's land can effect a taking even if the planes do not physically invade the airspace directly over $A$ 's land. See infra text accompanying notes 141-49.

27. See infra text accompanying notes $150-467$ (discussing the moral justification principle).

28. R. EPSTEIN, TAKINGS (1985).

29. See infra notes $52,63,128,176,181,221,223,247,255,268,344,348,351,421 \& 461$ (contrasting the two approaches to the takings clause).

30. R. EPSTEIN, supra note 28, at 281. Because Epstein took on the normative task of inquiring when compensation should be paid, he is not concerned that his approach conflicts with existing law.

31. Epstein, A Last Word on Eminent Domain, 41 U. MIAMI L. Rev. 253, 275 (1986) (quoting Alexander, Takings of Property and Constitutional Serendipity, 41 U. MIAMI L. REV. 223, 223 (1986)). One important respect in which Epstein's takings clause theory is "complete" is that it addresses the takings issues raised by a broad range of governmental actions, including taxation, regulation, and physical action by the government. 
the takings clause in this Article, I do seek to provide a complete descriptive theory of when the Court will find that a compensable taking of property has occurred.

The theory I offer is, I behieve, the closest one can come to articulating a unified set of principles that describe when the Court will find a taking. Some readers may agree that this set of principles accounts for the great majority of the Court's takings decisions and for many generally accepted propositions as to when a taking occurs. Other readers may be persuaded that I have explained many of the cases, yet may beheve that principles other than the ones I have articulated would better explain a number of the Court's takings decisions. These readers will reject my claim that a unified theory can be used to explain these cases. Perhaps other readers either will seek to fornnulate a different unified theory to explain the Court's takings decisions, or will conclude that no set of principles can account for the Court's takings decisions.

I can only offer my theory of the takings clause, and welcome others to provide alternative theories that better explam when the Court will find a compensable taking. While conclusive proof that a given theory best explaims the Court's takings decisions is not possible, I mdicate $m$ this Article why my theory provides a better explanation than those articulated by either the Court or other leading commentators.

\section{PROPERTY}

I began to formulate a theory of when a compensable taking of property occurs by looking for a definition of "property" that would account for the wide range of cases im which the Court has exphicitly stated or imphicitly assumed that property was at issue. ${ }^{32}$ The Court, for example, has stated or assumed that a deprivation of property occurred (and thus a takings claim was properly raised) when the government prohibited the manufacture of beer; ${ }^{33}$ when it imposed a tax that threatened to put the claimant out of the parking garage business; ${ }^{34}$ when it required

32. In its takings decisions, the Court sometimes identifies the relevant "property" explicitly, while at other times it simply assumes that the challenged action constitutes a deprivation of property, and focuses on whether that deprivation amounts to a compensable taking.

Note that when the Court inquires whether a "taking" occurred, it is asking whether just compensation is due. If the claimant were seeking to enjoin the government's action, she would have to argue that the deprivation of property was not for a "public use." See First English Evangehical Lutheran Church v. County of Los Angeles, 482 U.S. 304, 314-15 (1987); Ruckelshaus v. Monsanto Co., 467 U.S. 986, 1016 (1984). The Court has held that the public use test is equivalent to the minimum rationality standard of substantive due process. See Hawaii Hous. Auth. v. Midkiff, 467 U.S. 229, 240-41 (1984).

33. Mugler v. Kansas, 123 U.S. 623 (1887).

34. City of Pittsburgh v. Alco Parking Corp., 417 U.S. 369 (1974). 
employers to fund vested pension benefits; ${ }^{35}$ when it enacted a law revoking certain insurance contracts it had issued; ${ }^{36}$ when it disclosed a pesticide manufacturer's data to the public, resulting in the loss of trade secrets; ${ }^{37}$ and when it required individuals to provide economically valuable services without receiving compensation at fair market value. ${ }^{38}$ Thus, takings claims are by no means himited to cases involving land ownership or land-use regulation. Rather, they arise in a wide spectruin of cases involving both tangible and intangible economically valuable resources.

It appears that the Court's decisions can best be accounted for by defining property in the following manner: ${ }^{39} A$ 's "property" consists of (1) the freedom to act in ways that are economically valuable to her, ${ }^{40}$ and (2) any economically valuable legal rights created by positive law that entitle her to force other private parties or the government to act in a certain mamier. ${ }^{41}$ An miportant qualification, however, is that when the government grants $A$ such economically valuable rights against other private parties or the government, it often reserves the power to modify or eliminate those rights through a change in the law refiecting a change

35. Connolly v. Pension Benefit Guar. Corp., 475 U.S. 211 (1986).

36. Lynch v. United States, 292 U.S. 571 (1934).

37. Ruckelshaus v. Monsanto Co., 467 U.S. 986 (1984).

38. In Hurtado v. United States, 410 U.S. 578 (1973), for example, the Court discussed various types of service that are required of citizens, including the obligation to appear as a witness. The Court stated that such an obligation is not a "taking" because there is a "public duty" to appear. Id. at 588-89. The Court did not argue that one's services are not "property," but rather that in these cases the deprivation of services is not a compensable "taking" because of the government's justification for its action. See the discussion of "civic obligations" at infra text accompanying notes 345-85.

39. It may well be that the definition of property that follows could be defended on a normative basis. See infra note 56. In this Article, however, I am not attempting to defend this definition of property in normative terms. Rather, I am merely stating that this is the only definition of property I have been able to formulate that accounts for the extremely broad range of cases in which the Court has explicitly stated or implicitly assumed that the government's action deprived the claimant of property, thus raising the issue of whether that deprivation effected a compensable taking.

As shown in Part I, one cannot account for the Court's takings deeisions simply by equating property with tangible things. It seems more promising to define property in tcrms of discrete economically valuable rights created by positive law. Yet it would be difficult to account for the Court's takings decisions by defining property solely in terms of economically valuable rights created by positive law. Morcover, there must be some way to account for the government's ability to grant economically valuable legal rights that are subject to change as public policy changes. See Peterson I, supra note 4, at 1344-51.

40. Thus, $A$ 's economically valuable liberty is her property. The phrase "economically valuable" is used because the claimant in a takings case is arguing that the government has harmed her economic interests. She is not simply complaining that the government has restricted her freedom. For example, if the government prohibited $A$ from marketing a book she had written, $A$ might complain that the government was infringing on her freedom to express her views. She also might complain that the govcrnment was preventing her from making a profit. Only the latter complaint could be formulated as a takings claim.

41. Such rights might be created by federal, state, or local law. 
in public policy. When the government subsequently acts pursuant to that reserved power, no deprivation of property occurs, because the government does not thereby take away anything it liad unconditionally given to $A .^{42}$

The government deprives $A$ of the first type of property when it deprives her of economically valuable liberty, either by requiring her to act in a certain manner or by prohibiting her from acting. For example, the government miglit require an attorney to perform certain legal services without receiving compensation; ${ }^{43}$ require an employer to provide funding for vested pension benefits; ${ }^{44}$ prohibit a manufacturer from producing certain products; ${ }^{45}$ or prohibit a landowner from using her land for certain economically valuable purposes. ${ }^{46}$ The government miglit also engage in pliysical action that effectively prevents a landowner from using her land for certain purposes. For exainple, the government might build a dam that causes fiooding of $A$ 's land. ${ }^{47}$

The government deprives $A$ of the second type of property when it deprives her of an economically valuable legal right to control the conduct of $B$ or the government. Such a deprivation occurs, for example, when the government uses its eminent domain power to acquire $A$ 's contract rights agaimst $B,{ }^{48}$ or wlien the government eliminates $A$ 's previously existing right to prevent the government from disclosing certain data containing trade secrets. ${ }^{49}$

42. See the discussion of "vested" and "nonvested" rights at infra text accompanying notes 62 72 and 83-103.

43. See, e.g., Family Div. Trial Lawyers v. Moultrie, 725 F.2d 695 (D.C. Cir. 1984) (requirement that practitioners in Family Division of D.C. Superior Court undertake pro bono representation of indigent parents in child neglect proceedings challenged as a taking).

44. See Connolly v. Pension Benefit Guar. Corp., 475 U.S. 211 (1986) (discussed at infra text accompanying notes $276-81$ ).

45. See, e.g., Mugler v. Kansas, 123 U.S. 623 (1887) (discussed at infra text accompanying notes 156-58, 252-55, and 503-06).

46. See, e.g., Penn Cent. Transp. Co. v. New York City, 438 U.S. 104 (1978) (discussed at infra text accompanying notes 107, 186-88, 246-47, 299-300, and 390-94).

47. See, e.g., Pumpelly v. Green Bay Co., 80 U.S. (13 Wall.) 166 (1871). The government also commits a taking through physical action when it prevents $A$ from using her land for certain purposes by making frequent low overflights, as in United States v. Causby, 328 U.S. 256 (1946) and Griggs v. Allegheny County, 369 U.S. 84 (1962).

When the government prevents $A$ from using a particular parcel of land in a certain economically valuable inanner, whether by legal or physical action, the "property" taken is $A$ 's freedom to act with respeet to the land, not the land itself. In Causby and Griggs, for example, the government required the claimants to "give up something of economic value" when it deprived them of the freedom to use their land for certain lawful and economically valuable purposes.

48. In Russian Volunteer Fleet v. United States, 282 U.S. 481 (1931), for example, the government aequired the claimant's rights under certain contracts for the construction of ships. Sinilarly, in United States v. General Motors Corp., 323 U.S. 373 (1945), the goverument condemned the claimant's rights under a lease.

49. See Ruckelshaus v. Monsanto Co., 467 U.S. 986 (1984) (discussed at infra text accompanying notes $92-102,113-22,282-84,328-31$, and 339-41). 
Under my proposed definition of property, takings claims could be raised in an extremely broad range of cases. ${ }^{50}$ This appears to be true under the current law. Yet this does not mean that the Court would find a taking in a large number of cases. The Court would still need to determine whether the deprivation of property constituted a compensable taking. ${ }^{51}$

Under my proposed definition, property is not solely a creature of positive law. If no law (other than the takings clause) had yet been enacted, $A$ 's property would consist of her freedom to behave in a manner that is economically valuable to her, both with respect to her own person $^{52}$ and with respect to other persons and things. ${ }^{53}$ Thus, the government is not free to withhold all property from private parties, nor may

50. The range of cases in which a takings claim might be raised is not as broad, however, as the range of cases in which a substantive due process clain might be raised. Takings claims are limited to those cases in which the government has deprived $A$ of property, while substantive due process claims can arise where the government has deprived $A$ of "life, liberty, or property." U.S. CoNSr. amend. V. As discussed at supra note 40 , not every infringenent of $A$ 's liberty is a taking of "property."

51. See the discussion at infra text accompanying notes $150-467$ of the broad range of cases in which no taking occurs because the government has a "moral justification" for depriving $A$ of her property.

Plainly, one must distinguish between noncompensable deprivations of property and compensable "takings" of property, for in many instances the government requires $A$ to give up her property and yet no taking occurs. For example, no coinpensable taking occurs if the governinent requires $A$ to forfeit something used in the conmission of a crime. Yet $A$ is being forced to give up her property, whether one defines "property" as the thing itself or certain economically valuable rights with respect to the thing.

The Court has at times explicitly recognized that not every deprivation of property is a compensable taking. In PruneYard Shopping Center v. Robins, 447 U.S. 74 (1980), for example, the Court acknowledged that the clainant had been deprived of the right to exclude others from its shopping eenter, and then stated:

But it is well established that "not every destruction or injury to property by governinental action has been held to be a 'taking' in the constitutional sense." Rather, the determination whether a state law unlawfully infringes a landowner's property in violation of the Taking Clause requires an examination of whether the restriction on private property "force[s] some people alone to bear public burdens which, in all fairness and justice, should be borne by the public as a whole."

Id. at 82-83 (quoting Armstrong v. United States, 364 U.S. 40, $48-49$ (1960)).

52. But cf. R. EPSTEIN, supra note 28 (relying on Locke, Epstein argued that "each individual owns his own labor," $i d$. at 11, although he later concluded that the takings clause "is limited to private property, which should probably be read not to include the disposition of labor as such," $i d$. at 250 n.40).

53. While the government would, of course, soon enact laws restricting that freedo1n, those laws would not effeet compensable takings of $A$ 's property, under the analysis proposed in this Article, if they were designed to prevent or punish wrongdoing by $A$. For example, a law prohibiting $A$ and others from using force to deprive others of the fruits of their labor would not effect a taking, because the lawinakers could rcasonably conclude that such conduct would be considered wrongful. Note that such a law also protects the fruits of $A$ 's labor, and thus increases the value of her economically valuable freedoin.

Indeed, it is generally true that "type one" property is made more valuable because there arc laws creating "type two" property. For example, $A$ 's freedom to grow and harvest crops would be far less valuable if she had to rely on her own actions to protect the fruits of her labor than if the law 
it provide that all property is granted subject to modification or revocation by the government.

The significance of this definition is apparent if one considers the imphications of an alternative definition of property that restricts property to economically valuable rights created by positive law. Under such an approach, if no law other than the takings clause had been adopted, $A$ would have no property. If the first law that was enacted prohibited $A$ from engaging in certain conduct, it would not deprive $A$ of any property. Nor would $A$ be deprived of property if the first law that was enacted required $A$ to perform uncompensated services that were economically valuable to others. ${ }^{54}$ Moreover, when the government chose to grant $A$ certain economically valuable legal rights, it could retain the power to revoke those rights at any time. ${ }^{55}$ The government could thus create a situation in which no compensable taking would occur even if the government demed $A$ all control over the economic value of her own conduct. $^{56}$

granted $A$ the right to have the govermment force $B$ to return $A$ 's crops (or pay damages) if $B$ stole them from her.

54. These issues could also arise in the present day. Suppose, for example, that $A$ is an attorney and that the government enacted a law before $A$ was born, providing that all lawyers must perform 500 hours of free work for the government each year. If property were solely a creature of positive law, this law would not deprive $A$ of any property, since she never acquired a legal right not to provide such services to the government.

55. For example, the government might enact a law providing that the right to build on one's land or the right to physically exclude others from one's land is a privilege that can be revoked by the government at any time.

56. Although my proposed definition of property is designed to explain the results in the Court's takings decisions, it is also appealmg on a normative basis, because it denies the government the power to provide that all economically valuable resources (including $A$ 's own labor) are the property of the government. Not surprisingly, most commentators agree that "property" for takings clause purposes inust embrace more than rights created by positive law. Laurence Tribe, for example, has stated:

[E]ven if the government has in fact taken care to announce that all property acquired in the jurisdiction is held subject to government's limitless power to do with it what government wishes[,] we must deny government the power to inake any such announcement, or at least to give such an announcement legal effect, if we are to give content to the compensation clause. But this shows that the expectations protected by the clause must have their source outside the positive law of the state. Grounded in custom or necessity, those expectations achieve protected status not because the state has deigned to accord them protection but because constitutional norms entitle them to protection.

L. Tribe, American CONSTITUtional LAw 465 (1978) (emphasis in original); accord R. EPSTEIN, supra note 28, at 304-05 (" $[t]$ he eminent domain clause is designed to limit the power of the legislature; it can achieve that end only if it accepts some natural law aecount of property that is able to resist legislative nullification"); Dunham, Griggs v. Allegheny County in Perspective: Thirty Years of Supreme Court Expropriation Law, 1962 SuP. CT. REv. 63, 80-81 (if the principle that property consists only of those economic advantages that have the sanction of the law behind them were followed to its logical conclusion, "government could redefine property rights as subordinate to all government claims and then destroy, take, or damage without compensation because no "property rights' were taken"); Michelman, Property as a Constitutional Right, 38 WASH. \& LeE L. REV. 1097, 1103 (1981) ("derivative property rights are not the only ones the Constitution creates or protects, 
Nollan v. California Coastal Commission ${ }^{57}$ strongly supports the view that "property" includes the freedom to pursue economically advantageous activities even when no law affirmatively grants such a right. The Nollans purchased beachfront land at a tiune when the Calfornia Coastal Act provided that "public access . . . along the coast shall be provided in new development projects."58 Thus, the Nollans did not acquire a right under state law to build on their land without providing pubhic access. Nevertheless, the Supreme Court found that a taking would occur if the state refused to permit the Nollans to build on their land unless they provided free public. access.

What "property" was taken in Nollan? Under the definition of property that I propose in this Article, the Nollans' econoinically valuable freedom to build on their lot without providing public access was taken from them. 59 This was their "property," even though under state law the Nollans had never acquired the right to build without providing public access. As the Court expressed it im Nollan, the right to build could not be viewed as simply a "governmental benefit" that the government had not granted to the Nollans. ${ }^{60}$

My proposed defimition of property assumes that $A$ initially possesses the freedom to behave im ways that are economically valuable to lier, but does not imitially possess the right to have the government force another private party or a governmental entity to act in ways that are economically valuable to her. If the government does, however, grant $A$ that right, ${ }^{61}$ the takings clause restricts the government's ability to subse-

and . . . standing law can[not] supply . . . a perfectly complete . . . definition of constitutionally protected property") (einphasis in original).

57. 483 U.S. 825 (1987).

58. Cal. Pub. Res. CODE $\S 30212$ (a) (West 1986). Pursuant to this statute, the Coastal Commission had announced and was implementing a policy of permitting building along the coast only if public access was provided. Nollan, 483 U.S. at $833 \mathrm{n.2}$ (opinion of the Court); id. at $857-60$ (Brennan, J., dissenting).

59. Because the Nollans were required to formally dedicate an casement to the public, one could say that the government not only was depriving the Nollans of economically valuable liberty (the first type of property), but also was forcing the Nollans to transfer to the governinent an economically valuable legal right against others (the second type of property). Yet the holding in Nollan does not appear to rest on the fact that this formal transfer was required. The Court's reasoning strongly supports the conclusion that the Court would have found a taking if state law had sinply provided that anyone who builds on beachfront land inust permit the public to walk across the beach on his land.

60. 483 U.S. at 834 n.2. Thus, the inajority viewed this as a case in which the Nollans, having purchased this parcel of land from the prior owners, acquired the freedoin to build on it. This became their "property" regardless of the provisions of state law pertaining to public coastal access at the time the Nollans purchased the land. As discussed below, see infra text accompanying notes 202-06, the Nollans suffered a compensable taking because the governinent intentionally deprived them of their property, and the government was not seeking to prevent or punish wrongdoing.

61. When the government grants $A$ the power to force another private party $(B)$ to behave in ways that are economically valuable to $A$, the governinent is interfering with $B$ 's economically valuable freedom. This grant of power to $A$ will be a taking from $B$ unless the lawmakers are seeking 
quently deprive her of this property without paying just compensation. This type of property, which is created by positive law, falls under the second part of my definition of property.

The notion that the takings clause restricts the government's ability to deprive $A$ of "type two" property must be qualified by the principle that many legal rights are granted conditionally. When the government enacts a law granting $A$ an economically valuable legal right against $B$ or the government, the lawmakers often expressly or implicitly grant that right only until a change in the law reflecting a change in public policy eliminates the right. ${ }^{62}$ The Court often expresses this by saying that the law was not intended to create "vested" rights. ${ }^{63}$ When the government later exercises its reserved power to change the law, it is not taking back anything it has unconditionally given to $A$. Alternatively expressed, the government is not reneging on any promises. Although $A$ may lose economically valuable legal rights against $B$ or the government because of a change in the law, the government is not depriving $A$ of property, and therefore no taking occurs. ${ }^{64}$ By granting only nonvested rights to $A$, the government reserves the power to terminate $A$ 's economically valuable legal rights against $B$ or the government through a change in the law designed to proinote the common good.

Sometimes it is clear that the lawnakers intend to preserve flexibility when they grant certain economically valuable legal rights to private parties. For example, Congress clearly intended to reserve the right to alter the level of AFDC benefits. ${ }^{65}$ In many cases, however, it is not clear whether the lawmakers intended to grant "vested" economically

to prevent or punish wrongful conduct by $B$. For example, if the government granted $A$ the right to force $B$ to perform under a contract, the government would be depriving $B$ of his economically valuable liberty. No taking would occur, however, because the lawmakers could reasonably regard $B$ 's unjustified failure to fulfill his promise as wrongful.

By way of contrast, when the government grants $A$ an economically valuable legal right against the government, it need not be seeking to prevent or punish wrongdoing by the government. No taking will occur if the government decides to give something of economic value to $A$ to promote the common good, even though it would not be wrong of the government to fail to do so.

62. The new law would, of course, have to meet the requirements of minimum rationality. As discussed at infra note 153, the minimum rationality standard would not be satisfied if the new law served purely private ends or if it was wholly arbitrary. See, e.g., Webb's Fabulous Pharmacies, Inc. v. Beekwith, 449 U.S. 155 (1980) (discussed at infra text accompanying notes 89-91).

63. See Peterson I, supra note 4, at 1313-15.

In Takings, Epstein rejeeted the notion that $A$ might not have a "vested right" in a liability rule (such as a strict liability standard in tort), and asserted that "all modifications of liability rules are takings of private property prima facie compensable by the state." R. EPSTEIN, supra note 28, at 95 (emphasis in original).

64. Note that the argument that the government gave $A$ the right conditionally applies only to "type two" property, since the first type of property is not dependent on government grant.

65. "Congress is not, by virtue of having instituted a social welfare program, bound to continue it at all, much less at the same benefit level." Bowen v. Gilliard, 483 U.S. 587, 604 (1987). 
valuable legal rights. ${ }^{66}$ In case of doubt, the Court has stated that it will presume that no vested rights were intended: "[A]bsent some clear indication that the legislature intends to bind itself contractually, the presumption is that 'a law is not intended to create private contractual or vested riglits but merely declares a policy to be pursued until the legislature shall ordam otherwise." "67 Thus, in many takings cases involving a change in the law, the claimant will not be able to establish a taking of "type two" property, because the government will be able to argue successfully that it acted within its reserved power to eliminate the claimant's legal rightit. ${ }^{68}$

There are cases, lowever, in which the lawmakers ratlier clearly made a commitment or "promise" to $A$, tliereby granting her a "vested"

66. In Flemming v. Nestor, 363 U.S. 603 (1960), for example, the majority concluded that Congress had reserved the power to modify the Social Security Act, even if that modification would result in the reduction or even termination of benefits paid to individuals who had made contributions to the Social Security System for many years. In effect, the Court concluded that the government had not made a commitment to these individuals. The dissenters, however, argued vigorously that social security benefits are not "gratuities," id. at 631 (Douglas, J., dissenting), and that the government was "break[mg] its phighted faith," just as it had in Lynch v. United States, 292 U.S. 571 (1934) (discussed at infra text accompanying notes 69-72, 197-200, 307-12, and 526-27). Flemming, 363 U.S. at 624 (Black, J., dissenting).

Bruce Ackerman has explained cases like Flemming $v$. Nestor by saying that "the courts have failed to recognize the relevance of takings law in protecting the expectations of millions who have legal property in the Social Security and welfare programs" because these cases do not involve "social property." B. ACKerman, PRIVATE Property AND THE CONSTITUTION 165 (1977). "Social property" exists only if the claimant can "point to existing social practices which any wellsocialized person should recognize as marking a thing out as [the claimant's] thing." Id. at 117.

By way of contrast, this Article explains such cases by saying that when $A$ claims that a change in the law depriving her of an cconomically valuable legal right against $B$ or the government was a "taking," the first issue that must be addressed is whether the government made a commitment to $A$ when it granted that right, or whether the government reserved the power to change the law to reflect a change in public policy.

67. National R.R. Passenger Corp. v. Atchison, T. \& S.F. Ry., 470 U.S. 451, $465-66$ (1985) (quoting Dodge v. Board of Educ., 302 U.S. 74, 79 (1937)).

In many cases, the government is not likely to change the law to eliminate nonvested "typc two" property rights, even though in principle it could. For example, when the government grants $A$ the right to recover damages from $B$ for negligently causing physical injury to $A$, the government may not be granting $A$ a "vested right" to recover from $B$ under a negligence standard. Yet there is such a widely held belief that $B$ is morally obligated to compensate $A$ in such cases that it seems unlikely that the law would be changed to eliminate $A$ 's cause of action against $B$. Similarly, there is a widely held belief that it is wrong of $B$ to steal, and thns it is highly unlikely that the government would eliminate $A$ 's cause of action against $B$ for conversion, even if the government never granted $A$ a "vested right" to have the government enforce such a claim against $B$. As discussed at supra note 53 , the existence of "type two" property rights can greatly enhance the value of "type one" property rights. This is true even if the "type two" property rights are not "vested rights."

68. For example, suppose that the law at Time 1 granted $A$ the right to build an office building on her land, but that no "vested right to build" was granted. Then at Time 2 the lawmakers downzoned the land to permit residential use only. What type of property has $A$ lost here? She has lost the first type of property-the economically valuable freedom to act in a certain manner with respect to the land. However, she has not been deprived of the second type of property, because the government was acting within its reserved power. 
economically valuable legal right. For example, the Court concluded in Lynch v. United States ${ }^{69}$ that when the federal government issued renewable term insurance policies under the War Risk Insurance Act, it created "vested rights," not "gratuities [that could] be redistributed or withdrawn at any time in the discretion of Congress."70 The Court's decision in Lynch could be explained using the principles offered in this Article by saying that a taking occurred because the government took back a vested right that it had given to $A,{ }^{71}$ and the government was not preventing or punishing wrongdoing by $A .^{72}$ It is not sufficient to say that the government granted $A$ this right originally, for the takings clause does not rest on the proposition that what the government gives, the governinent niay take away.

To sonie extent the Court's definitions of property can be harmonized with the definition offered here. The only definition the Court has used that plainly cannot be reconciled with the definition I offer in this

69. 292 U.S. 571 (1934).

70. Id. at 577 .

71. Under my analysis, it would be an issue of federal constitutional law whether the government had granted $A$ a "vested right." In resolving that issue, however, the court would consider whether the federal, state, or local lawmakers explicitly or implicitly made a commitment when they granted $A$ the right at issue.

Consider, for example, vested rights to build. In many states, state law provides that $A$ acquires a vested right to build a particular structure when a building permit has been lawfully issued and $A$ has materially changed her position in reliance on the permit. R. Ellickson \& A. TARLOcK, LAND-USE CONTROLS 205 (1981). Only then is a commitment made to $A$. In the State of Washington, however, state law provides that a vested right to build is acquired when $A$ applies for a building permit. If $A$ 's proposed structure complies with the applicable zoning ordinance at the time she applies for a building permit, then she has a right to build that structure even if the zoning changes before $A$ materially changes her position in reliance on the permit. Parkridge v. City of Seattle, 89 Wash. 2d 454, 464-66, 573 P.2d 359, 366 (1978). Thns, in the State of Washington, a commitment is made to $A$ at an earlier point. Using my approach, if $A$ 's takings claim were based on the revocation of a building permit, the court would first determine whether the government had made a commitment to $A$, and therefore whether the government was depriving her of a "vested" economically valuable legal right. It would then consider whether the government had a "moral justification" for depriving $A$ of that vested right. See the discussion at infra text accompanying notes 303-31.

By way of contrast, in Private Property and the Constitution, Ackerman argued that the takings issue presented by the revocation of a building permit is not affected by the content of state law regarding vested rights to build. Rather, he argued that the claimant does not acquire "property" for takings clause purposes until he has "made a substantial change in the land, or incurred substantial expenditures or obligations in reliance on the permit ... thereby placing himself in a situation at least analogous to those where [a structure] is in actual existence . ..." B. ACKERMAN, supra note 66, at $239 \mathrm{n} .22$ (emphasis in original). Only then would the claimant's right to build qualify as "social property." For more on "social property," see supra note 66.

The Court has not yet resolved a takings claim based on the revocation of a vested right to build. Such a claim was raised in Williamson County Regional Planning Commission v. Hamilton Bank, 473 U.S. 172 (1985), but the Court concluded that the claim was not ripe. Id. at 186; see infra note 327 (discussing Williamson County).

72. See infra text accompanying notes 307-12. 
Article is the one equating "property" with tangible things, such as parcels of land.

When the Court equates "property" with a tangible thing, it generally then asks whether the government deprived the claimant of that thing. For example, the Court may define the thing as the "parcel as a whole" and then ask whether the challenged law denies the clainant all "economically viable use" of the parcel as a whole, effectively depriving the claimant of the parcel of land. Using this approach, the Court finds no compensable taking of property if the clainant has not effectively been deprived of the relevant thing. ${ }^{73}$ For example, in Hodel v. Virginia Surface Mining \& Reclamation Association, ${ }^{74}$ the Court found that a statute regulating surface mining on steep slopes and prohibiting surface mining near certain locations did not effect a taking because it did not deprive landowners of all economically viable use of their coal-bearing land. ${ }^{75}$ Similarly, in Andrus v. Allard, ${ }^{76}$ the Court found that the Eagle Protection and Migratory Bird Treaty Acts, which prohibited commercial transactions in parts of birds protected by the Acts, did not effect a taking because the claimants had not been deprived of all economic benefit of the bird artifacts. ${ }^{77}$ The fact that the claimants had been deprived of some of their rights with respect to the artifacts was not deeined suffi-

73. Similarly, in Private Property and the Constitution, Ackerman explained the Court's takings clause decisions by defining "property" in terms of things that are widely recognized as the claimant's things. See supra note 66 . He argued that the claimant makes a prima facie case of a taking only if he shows that the government has deprived him of his thing. B. ACKERMAN, supra note 66 , at 145 . Ackerman acknowledged, however, that this definition of property does not provide an adequate tool for deciding modern takings cases:

Unlike our ancestors, we no longer count our wealth by looking first to our social property of land, farms, buildings. Instead, our principal means of support consist of legal property: stocks, bonds, pensions, an assortment of rights granted by the activist welfare state. . . . [A judge whose conception of property is limited to "social property"] is simply without the analytic means to assess the constitutional siguificance of the great sea change that has transformed property in the twentieth century.

Id. at 166.

74. 452 U.S. 264 (1981).

75. Along the same lines, Bruce Ackerman sought to explain the Court's takings decisions in Private Property and the Constitution by saying that a prima facie case of a taking does not arise if the government has merely prohibited the claimant from making a particular use of his land, "since he can point to no thing which has been taken from him by the new regulations." B. ACKERMAN, supra note 66 , at 159. Ackerman concluded, however, that a law that required the termination of an existing land use would be viewed as taking one of the claimant's "things," even though the law would not deprive the claimant of all possible uses of his land. Id. at 132. Under Ackerman's theory, no takings issue would arise in a case like Agins v. City of Tiburon, 447 U.S. 255 (1980), where the government limited the density of future residential development of the claimant's land, because the government would neither be depriving the claimant of all use of his land, nor would it be depriving the claimant of an existing use of his land. Under my analysis, a takings issue would arise in Agins because the government would be depriving the clainant of the economically valuable hiberty to use his land in a certain manner.

76. 444 U.S. 51 (1979).

77. Id. at 66 . 
cient to raise a takings claim. ${ }^{78}$

However, as shown in Part $I,{ }^{79}$ the Court has sometimes stated that "property" for takings clause purposes consists of economically valuable legal rights, not tangible things, ${ }^{80}$ and the Court has often found a compensable taking of property even where the claimant had not been deprived of an entire physical thing. ${ }^{81}$ This imconsistency in the Court's analysis of takings claims would be ehminated under my two-part definition of property. According to this view, a law that prohibits $A$ from using her land for a particular purpose deprives $A$ of her "property" because it limits her freedom to behave in a certain economically valuable manner with respect to her land. A deprivation of "property" occurs even though the law does not deprive $A$ of all economically beneficial use of the land and thus does not effectively deprive her of the "parcel as a whole." Therefore, a deprivation of "property" would be found far more readily under this approach than under the Court's "parcel as a whole" approach. Such a deprivation, however, would not necessarily effect a compensable taking. The Court would still have to examine the government's justification for depriving $A$ of her property to determine whether there was a compensable taking. ${ }^{82}$

Turning now to those cases in which the Court has defined "property" in terms of econoumcally valuable legal rights or vested economically valuable legal rights, what relationship is there between those defimitions of property and the definition I offer? Under the second part of my proposed definition, rights created by positive law that entitle $A$ to force other private parties or the government to behave in a certain man-

78. In addition, the Court often seems to assume that a taking would occur if the government were to deprive a claimant of an entire thing. For example, the Court has often assumed that one way to establish a taking would be to show a denial of all economically viable use of a parcel of laud. Occasionally, however, the Court has recognized that there imight be circumstances in which there would be no taking even if the claimant were deprived of all economically beneficial use of a thing or a parcel of land. For example, in First English Evangehical Lutheran Church v. County of Los Angeles, 482 U.S. 304 (1987), the Court suggested that even if an ordinance prohibiting construction in a floodplain deuied the claimant all economically beneficial use of the land, a taking might not occur, because the derial of all use might be "insulated as a part of the State's authority to enact safety regnlations." Id. at 313. Thus, the Court occasionally has recognized that the government may take an entire thing from a private party without payment of compensation if a certain type of justification is shown.

79. See Peterson I, supra note 4, at 1310-12, 1345-46.

80. See, e.g., United States v. General Motors Corp., 323 U.S. 373, 377-78 (1945).

81. See, e.g., Nollan v. California Coastal Comm'n, 483 U.S. 825 (1987); United States v. Causby, 328 U.S. 256 (1946).

82. See infra text aecompanying notes $150-467$ (discussing the moral justification principle).

As shown in the section on moral justification, the definition of property and the moral justification principle, taken together, explain how the Court could find a taking in a number of cases in which the government had deprived the claimant of only a portion of a larger physical thing, and how it could find no taking in a number of cases in which the government lad deprived the claimant of an entire physical thing. See infra text aecompanying notes 471-74. 
ner constitute "property." However, if the government reserves the power to alter or terminate those rights through a change in the law reflecting a cliange in public policy, no taking occurs when the governinent acts within that reserved power. One could say that the governinent is not depriving $A$ of soinething it had given $A$ unconditionally, or that the government is not depriving $A$ of "vested rights."

The Court has not explained why in soine takings cases it defines property in terms of "vested rights," 83 while in other cases it defines property in terms of rights created by state law, without asking whether those riglits are "vested." 84 Yet, in some cases there is no need to inquire whether the economically valuable right that $A$ lost was a vested right, since the government is not exercising any power it may have reserved to ehminate that riglt. For example, the vested rights distinction is irrelevant in an eminent domam proceeding in which the government condemns $A$ 's economically valuable legal rights against $B$. If the government condemns $A$ 's rights agamst $B$ under a lease, it does not change the law governing the rights of lessees. It simply transfers $A$ 's rights under current law to the government. Thus, in United States $v$. General Motors Corp. ${ }^{85}$ where the government condemned a leasehold interest, the Court properly spoke of the government acquiring certain rights froin $A$ without inquiring whether the government had retained the power to inodify or eliminate those rights.

The saine principle might apply in a takings case involving the enactinent of a law that applies to $A$. Suppose the government enacted a law requiring $A$ to transfer her econoinically valuable claim against $B$ to the government under certain circumstances. There would be no need to determine whether the government had reserved the power to modify or ehininate this claim, since the government did not even purport to be exercising such a power. For exainple, in Bowen v. Gilliard, ${ }^{86}$ the governinent required any child entitled to receive support payments from a noncustodial parent to assign that claim to the state if the custodial parent applied for AFDC benefits. The government did not purport to be exercising the power to inodify or eliminate the child support obligation of the noncustodial parent. Thus, there was no need for the Court to ask

83. See Peterson I, supra note 4, at 1313-15.

84. Id. at 1310-12. In such cases, the Court sometimes uses the definition of property taken from Board of Regents v. Roth, 408 U.S. 564 (1972), a procedural due process case, which stated that " "[p]roperty interests . . . are not created by the Constitution. Rather, they are created and their dimensions are defined by existing rules or understandings that stem from an independent source such as state law ... " " Webb's Fabulous Pharmacies, Inc. v. Beckwith, 449 U.S. 155, 161 (1980) (quoting Roth, 408 U.S. at 577).

85. 323 U.S. 373 (1945).

86. 483 U.S. 587 (1987). 
whether the government had deprived the claimant of a "vested right."87

Finally, in other cases there is no need to inquire whether the government reserved the power to alter or eliminate $A$ 's rights, because the challenged law does not even ineet the requireinents of minimuin rationality, and thus is beyond the bounds of any power the government may have reserved. ${ }^{88}$ In Webb's Fabulous Pharmacies, Inc. v. Beckwith, ${ }^{89}$ for example, the Court upheld a takings challenge to a Florida statute providing that interest accruing on interpleader funds deposited in the registry of the county court would be "deemed" income of the office of the clerk of the court. The Court viewed Webb's as a case in which the corporation's creditors had a "state-created property right to their respective portions of the fund." 90 The Court assumed that "property" had been taken because the government had deprived the claimants of certain econoinically valuable legal rights created by state law. It did not inquire whether those rights were subject to change by subsequent legislation or whether they were "vested rights." Rather, it stated that the Florida legislature could not simply "recharacteriz[e] the principal as "pubhic inoney" "while it was held by the court, for that would be an "arbitrary use of governmental power" and would effect a taking. ${ }^{91}$ Although the Court did not analyze the case in terins of the vested rights distinction, it could have stated that because the challenged law did not even meet the mimimum rationality standard, the government could not have been acting within any reserved power to modify the creditors' legal rights to these funds.

There are cases, then, in which $A$ claims that a taking occurred when she was deprived of an economically valuable legal right against $B$ or against the government, and there is no need to determine whether a "vested right" was taken, either because the government did not purport to be acting within its reserved power or because the government exceeded the bounds of any power it inay have reserved. In other cases, however, it is critical to determine whether the government reserved the power to modify or eliminate a particular economically valuable legal right. At times the Court addresses this issue by exphcitly discussing

87. The Court, however, asserted that one reason this was not a taking was that the child's rights against the noncustodial parent were subject to modification under state law and therefore were not "vested." Bowen v. Gilliard, 483 U.S. at 607-08.

88. See supra note 62 .

89. 449 U.S. 155 (1980).

90. Id. at 161. The Court relied on the Roth definition of property. See supra note 84 .

91. Webb's, 449 U.S. at 164. The Court explained that the county was not retaining the interest as a fee for its services, because a separate fee was already being charged for services rendered by the county clerk's office. The Court concluded: "No police power justification is offered for the deprivation. Neither the statute nor appellees suggest any reasonable basis to sustain the taking of the interest earned by the interpleader fund. ... [A] State, by ipse dixit, may not transform private property into public property without compensation . . . ." Id. at 163-64. 
whether "vested rights" have been lost. In recent years, however, the Court has not always used "vested rights" language when inquiring whether the government made a commitment to $A$ when it granted her certain economically valuable legal rights. The clearest example of this is Ruckelshaus v. Monsanto Co. ${ }^{92}$

Monsanto, a manufacturer of pesticides, clained that certain provisions of the Federal Insectide, Fungicide, and Rodenticide Act (FIFRA) ${ }^{93}$ effected a taking of its property. Under FIFRA, when a manufacturer of pesticides seeks to register a pesticide, the inanufacturer may be required to submit to the EPA certain data relating to the pesticide's effects on health, safety, and the environinent. Registration is required prior to marketing the product in the United States. Prior to 1972, FIFRA was silent as to whether the EPA could publicly disclose this health and safety data. In 1972, Congress ainended FIFRA to provide that the EPA could not publicly disclose health and safety data containing trade secrets or commercial or financial information. Congress again amended FIFRA in 1978 to provide that the EPA could publicly disclose certain health and safety data submitted by applicants. Monsanto claimed that this "data-disclosure" provision of FIFRA constituted a compensable taking of trade secrets ennbodied in the data.

The Court apphed the Board of Regents v. Roth ${ }^{94}$ definition of "property"9s in Monsanto. Looking to state law, the Court concluded that trade secrets were "property." 96 Because Monsanto's trade secret rights with respect to the data would be lost if the data were disclosed to the public, the Court viewed disclosure of the data as a deprivation of trade secrets, and thus a deprivation of property. ${ }^{97}$ The Court then considered whether that deprivation was a coinpensable taking under the Penn Central test. The key factor, in the Court's view, was whether the government had interfered with Monsanto's "reasonable, investmentbacked expectations." The Court concluded that there was no interfer-

92. 467 U.S. 986 (1984).

93. Federal Insecticide, Fungicide, and Rodenticide Act as amended by Act of Sept. 30, 1978, Pub. L. No. 95-396, 92 Stat. 819-42 and Act of Oct. 21, 1972, Pub. L. No. 92-516, 86 Stat. 973 (currently codified as amended at 7 U.S.C. $\$ \S 136-136 y$ (1988)).

94. 408 U.S. 564 (1972).

95. See supra note 84.

96. Although the Court relied primarily on the Roth definition of property, it also stated that " $t]$ rade secrets have many of the characteristics of more tangible forms of property," since they are assignable, can form the res of a trust, and pass to a trustee in bankruptcy. Monsanto, 467 U.S. at 1002. Moreover, the Court remarked: "[The] general perception of trade secrets as property is consonant with a notion of 'property' that extends beyond land and tangible goods and includes the products of an individual's 'labour and invention.'" Id. at 1002-03 (citing $2 \mathrm{~W}$. BLACKSTONE, Commentaries *405, and J. Locke, The Second Treatise of Civil Government, ch. 5 (J. Gough ed. 1947)).

97. "Once the data that constitute[] a trade secret [arc] disclosed to others . . the holder of the trade secret has lost his property interest in the data." Id. at 1011. 
ence with Monsanto's reasonable, investment-backed expectations with respect to data submitted to the EPA after the 1978 amendments to FIFRA took effect, because Monsanto had submitted the data knowing that the government would disclose it. ${ }^{98}$ Thus, disclosure of that data would not effect a taking. With respect to data subinitted prior to 1972 , when the statute neither promised confidentiality nor warned that the EPA might disclose the data, the Court concluded that Monsanto should have foreseen that the government might take the action coinplained of, given the history of regulation of the industry. ${ }^{99}$ Again, the Court found no taking. With respect to data submitted between the 1972 and 1978 amendinents to FIFRA, however, the Court concluded that the governinent had violated its "exphicit guarantee" that the data would not be disclosed, that the breach of this promise would frustrate Monsanto's reasonable, investınent-backed expectations, and that such action would therefore effect a taking. ${ }^{100}$

Although the Court did not employ the notion of vested and nonvested rights in Monsanto, it could have reached the same result by finding that the government had granted Monsanto a "vested right" when it expressly guaranteed that it would not disclose the data. That vested right was Monsanto's "property," which the government took when it changed the law in 1978 to authorize the EPA to disclose the data. Thus, unless the government was preventing or punishing wrongdoing when it deprived Monsanto of that vested right, a compensable taking occurred. ${ }^{101}$ Monsanto, however, had no "vested right" to nondisclosure of the data it had submitted before the 1972 or after the 1978 amendments. Congress gave Monsanto no right to prevent the governinent's disclosure of data submitted after the 1978 amendinents. And prior to 1972, when the statute was silent as to disclosure, Congress did not give Monsanto a "vested right" to nondisclosure. Because the governinent had reserved the power to change the law to reflect a change in public policy, the subsequent change in the law authorizing disclosure of data submitted prior to 1972 did not effect a taking. ${ }^{102}$

As Monsanto illustrates, the Court's analysis of takings clains would soinetimes be considerably inodified if the Court were to adopt the definition of "property" offered in this Article. Yet in the vast niajority of cases, the Court could arrive at the same conclusion as to whether a conipensable taking of property had occurred. One obvious advantage of

98. Id. at 1005-08.

99. Id. at 1008-10.

100. Id. at 1010-14.

101. Takings cases in which the government has reneged on its commitments are discussed at infra text accompanying notes 303-31.

102. Monsanto is discussed more fully at infra text accompanying notes $113-22$, 282-84, 328-31, and $339-41$. 
the approach offered here is that it permits the Court to apply a consistent definition of property in its takings decisions, rather than changing its views on what constitutes "property" from one opinion to the next. ${ }^{103}$

\section{II \\ FORCE}

A taking occurs only when the government forces $A$ to give up her property. No taking occurs if $A$ voluntarily gives up her property or voluntarily agrees to exchange it for something else of economic value.

There are three primcipal ways in which the government can force $A$ to give up something of economic value. First, the government may use an eminent domain proceeding to force $A$ to transfer her claim to an economically valuable resource, such as a parcel of land, to the government. ${ }^{104}$ The government thereby deprives $A$ of her freedom to use the land for certain econonically valuable purposes, and it also deprives her of whatever economically valuable legal rights against others she may have possessed by virtue of being the acknowledged owner of the land. ${ }^{105}$

Second, the government inay adopt a law that expressly requires $A$ to give up something of economic value. ${ }^{106}$ Consistent with iny two-part definition of property, a new law could force $A$ to give up her property in two types of situations. First, the law might deprive $A$ of the freedom to behave in a inanner that was economically valuable to her. For example, in Penn Central Transportation Co. v. New York City, ${ }^{107}$ the government deprived the clainnants of the freedom to build an office building on top of Grand Central Terminal. Second, the law might deprive $A$ of certain economically valuable rights against $B$ or the governinent that she had previously acquired. For example, in Lynch v. United States, ${ }^{108}$ the challenged statute deprived the clainants of their rights under insurance contracts that the government had issued under the War Risk Insurance Act.

103. This in turn would enable litigants to predict how the Court would analyze a takings case. They would know when the Court would find that a deprivation of property had occurred and could then turn to the issue of whether that deprivation constituted a compensable taking.

104. As the Court stated in United States v. General Motors Corp., 323 U.S. 373 (1945): "When the sovereign exercises the power of eminent domain it substitutes itself in relation to the physical thing im question in place of him who formerly bore the relation to that thing, which we denominate ownership." Id. at 378.

105. For example, $A$ would have acquired the economically valuable legal right to have the government use force to exclude others from her land.

106. It is also possible that a law that expressly required $A$ to give up one economically valuable resource $(\mathrm{X})$ would in effect force $A$ to give up another economically valuable resource $(\mathrm{Y})$. For example, a law that required $A$ to pay an extremely high tax if she engaged in a certain business might effectively prevent her from engaging in that business. See infra text accompanying notes 377 85.

107. 438 U.S. 104 (1978).

108. 292 U.S. 571 (1934). 
Finally, physical action by the government may force $A$ to give up something of economic value, even though no law requires $A$ to do so. In Pumpelly v. Green Bay Co., ${ }^{109}$ for example, a taking occurred when the government permanently flooded the claimant's land, thereby preventing him from using the land for certain lawful and economically valuable purposes. Similarly, in United States $v$. Causby, ${ }^{110}$ a taking occurred when the government made frequent low flights over the claimants' land, preventing the claimants from using their land as a chicken farm. ${ }^{111}$

In most takings cases, the government has clearly forced the claimants to give up their property. In some cases, however, a key point of contention is whether the facts establish a voluntary exchange or a forced transfer. Disagreement on this point often stems from uncertamty about what constitutes $A$ 's property. In Nollan v. California Coastal Commission, ${ }^{12}$ for example, Justice Brennan dissented, arguing that the Nollans had voluntarily exchanged an easenent for the right to build on their land. Brennan analogized the Nollans' situation to that of the pesticide manufacturers in Ruckelshaus v. Monsanto Co. ${ }^{113}$ who, during the period when the federal statute warned that submitted data would be subject to public disclosure, had voluntarily exchanged their confidential data for the right to inarket pesticides. ${ }^{114}$ The majority in Nollan agreed that Monsanto mvolved a voluntary exchange, but asserted that Nollan did not. ${ }^{115}$ As shown below, whether one would characterize each case as involving either a forced deprivation of property or a voluntary exchange depends upon one's view of what property the claimant owned. ${ }^{116}$

Both the majority and the dissent in Nollan viewed Monsanto as a case in which the government said: "If you give up $\mathrm{X}$, we will give you Z." As they saw it, Monsanto began with the right to prevent the government from using or disclosing its data $(\mathrm{X})$, and then voluntarily agreed to give up that right in exchange for the freedom to market its products (Z). The government's approval in Monsanto was viewed as a "government benefit."117

109. 80 U.S. (13 Wall.) 166 (1871).

110. 328 U.S. 256 (1946).

111. See also Griggs v. Allegheny County, 369 U.S. 84 (1962) (frequent low overflights that prevented the claimant from using his land for residential purposes effected a taking).

112. 483 U.S. 825 (1987).

113. 467 U.S. 986 (1984).

114. Nollan, 483 U.S. at $859-60$ (Brennan, J., dissenting).

115. Id. at 833 n.2.

116. Indeed, one reason it is important to have a consistent definition of "property" is so that one can determine whether a takings case involves a forcible transfer of property or a voluntary exchange.

117. Nollan, 483 U.S. at 833 n.2 (quoting Monsanto, 467 U.S. at 1007) (opinion of the Court); id. at 860 n.10 (Brennan, J., dissenting). 
The dissenters in Nollan argued that Nollan was analogous to Monsanto. In their view, the Nollans began with the right to exclude others from their land and were given the opportunity to exchange that right for the privilege of building. The dissent deemed the right to build a "government benefit," like the right to market a product in Monsanto. 18

The Nollan majority, however, saw the Nollans as starting with two things of economic value-the right to exclude others $(\mathrm{X})$ and the right to build, subject to certain "legitimate permitting requirements" (Y). ${ }^{119}$ In the majority's view, the government was saying, "You must either give up X or give up Y," rather than "If you give up X, we will give you Z." Froin this perspective, the case involved a forced deprivation, not a voluntary exchange. ${ }^{120}$

Under the definition of property I offer, both Monsanto and Nollan involved forced transfers, not voluntary exchanges, for in each case the claimant was forced to give up property. The government limited Monsanto's economically valuable freedoin of action by prohibiting Monsanto from marketing pesticides unless it transferred control of certain economically valuable data to the government. ${ }^{121}$ The government also limited the Nollans' econonically valuable freedom of action by prohibiting them from building unless they gave up the freedom to exclude others froin their land. ${ }^{22}$

There are not inany Supreme Court takings cases that focus on when a "voluntary exchange" occurs. Yet the issue is significant, for inany land-use laws might appear to involve voluntary exchanges, yet should be viewed as forced deprivations of property under the approach I suggest in this Article.

Consider, for example, an ordinance that gives a developer an "incentive" to build low-income housing units by providing that a greater density will be permitted in the development project if the developer constructs a certain amount of low-incoine housing. The developer seems to be getting something from the government in return for her

118. Id. at 860 n.10 (Brennan, J., dissenting).

119. Id. at 834 n.2.

120. Note that inquiring whether a "right" or merely a "governmental benefit" is at stake is another way of asking whether "property" is being taken.

121. That deprivation did not necessarily effect a compensable taki1ig, however. See infra notes 329-31 and accompanying text.

Note that Monsanto's complaints about the government limiting its economically valuable freedom amounted to complaints about a deprivation of "type one" property, while Monsanto's complaints about the loss of a previously existing legal right to prevent disclosure of the data by the government were complaints about a deprivation of "type two" property. See supra text accompanying notes 40-41; infra text accompanying notes 329-31.

122. The government was also depriving the Nollans of an economically valuable legal right against others ("type two" property), since the Nollans were required to formally dedicate an easement to the public. See supra note 59. 
voluntary act of building low-income housing umits. But one could also characterize the situation as one in which the government has said, "Either give us X or give us $\mathrm{Y}$. Either you must not develop above density level 1, or you must not develop above density level 2 and you must construct low-income housing." In either case, the governinent is depriving $A$ of the freedom to use her land in a certain economically valuable manner. Thus, under the principles offered in this Article, a compensable taking will occur unless the government has made a reasonable judgment that the proposed land use would be considered wrongful. ${ }^{123}$

Just as "incentive zoning" does not constitute a "voluntary exchange" under my proposed definition of property, neither does a development exaction, although some exactions may be couched in those terms. For example, suppose a local government enacted a law that provided, in effect, "If you pay a fee to support childcare centers, we will let you construct an office building downtown." This might appear to be a voluntary exchange. One might argue, as the dissent did in Nollan, that approval of the development should be considered a "government benefit." But under my definition of property, the law deprives the developer of property because it restricts her economically valuable freedom of action. That deprivation constitutes a compensable taking if the government is not seeking to prevent wrongdoing, but is simply forcing the developer to give up her property to promote the common good. ${ }^{124}$

\section{III}

\section{INTENT}

To commit a compensable taking of property, must the government intentionally deprive the claimant of her property, or could it do so inadvertently? The verb "to take" suggests deliberate action. But is an element of intent necessary to account for the Court's takings decisions? ${ }^{125}$

123. One of the issues in these "incentive zoning" cases is whether the restriction from which the developer is seeking relief is itself a taking. When the government limits the density to density level 1 , are the lawmakers seeking to prohibit conduct that they reasonably believe the public would consider blameworthy? Or is the government limiting the density to that level in order to obtain benefits by granting relief from that restriction? The Court in Nollan touched on this issue when it remarked in a footnote that "[o]ne would expect that a regime in which . . . leveraging of the police power is allowed would produce stringent land-use regulation which the State then waives to accomplish other purposes." 483 U.S. at 837 n.5.

124. In Nollan, the proffered judgment of wrongdoing was so implausible that the Court used the term "extortion." Id. at 837. The implication was that the government was marketing governmental approvals, not to prevent some wrong to the public, but simply to extract something of economic value from private parties.

125. At the outset it should be noted that the "intent" issue is not whether the government must intend to commit a compensable taking. The cases make clear that the government can commit a taking even if it does not realize that its action will be considered a taking. In United States v. Causby, 328 U.S. 256 (1946), for example, the Court found a taking even though the government 
In most takings cases, the government clearly intended to deprive the claimant of her property. When the government formally exercises its eminent domain power, for example, it plainly intends to force $A$ to give up her property. Similarly, when the government enacts a law that expressly requires $A$ to give up her property, no issue of intent arises. ${ }^{126}$ The intent issue is most likely to arise when the government engages in physical action that has the effect of forcing $A$ to give up her property. ${ }^{127}$ For example, suppose Congress authorized a federal agency to build a dam to provide hydroelectric power, and the dam caused flooding of $A$ 's land. Although the government clearly intended to build the dam, it may not have intended to flood $A$ 's land. In order for a compensable taking to occur, must the harm to $A$ have been intended? That is, must $A$ have been the identifiable victim of the government's action, just as she would be im a formal eminent domain proceeding-the paradigm case of a taking? The answer appears to be "yes," for it is difficult to explain the Court's takings decisions without articulating an intent requirement.

Suppose one said that a taking can occur if the government acts in a manner that results in depriving $A$ of her property, even if the government did not intend that deprivation to occur. The difficulty with this formulation is that it is widely accepted that many governmental torts involving the neghigent damage or destruction of economically valuable resources do not constitute takings. ${ }^{128}$ In fact the Court has stated this expressly in a number of cases. In Keokuk \& Hamilton Bridge Co. v.

plainly did not intend to effect a compensable taking when it made frequent low flights over the claimants' land. Similarly, the Court found a taking in Hodel v. Irving, 481 U.S. 704 (1987), even though Congress plainly did not realize that the government would have to pay just compensation when it enacted the challenged statute. Moreover, the Court's opinion in First English Evangelical Lutheran Church v. County of Los Angeles, 482 U.S. 304 (1987), seems to assume that a taking can occur during the interval between the enactment of a law and the date when a court first holds that the law effects a taking, even if the legislature did not intend to commit a taking when it enacted the law.

126. However, it is possible that a law that expressly required $A$ to give up one economically valuable resource $(X)$ might in effect force $A$ to give up another economieally valuable resource (Y). For example, a law that required $A$ to pay an extremely high tax if she engaged in a certain business might effeetively prevent her from engaging in that business. See infra text accompanying notes 377 . 85. In such a case, $A$ could not establish that the government had committed a taking of $Y$ unless she established that the government intended to force her to give up $Y$, not just $X$.

127. For example, the government might build a dam that caused flooding of $A$ 's land or it might make frequent flights over her land that prevented her from using it for certain purposes. This category of cases involving "physical action" by the government should be distinguished from cases in which a law expressly requires $A$ to permit the physical invasion of $A$ 's land or building or other tangible thing. For example, in Loretto v. Teleprompter Manhattan CATV Corp., 458 U.S. 419 (1982), the challenged statute required landlords to permit the installation of cable facilities on their buildings. Thus, the government plainly intended to deprive landlords of their property.

128. Nevertheless, Epstein argued in Takings that "there is no principled distinction between torts and takings," R. EPSTEIN, supra note 28, at 44, and that "[t]he rights of action afforded under the [Federal Tort Claims Act] should be regarded not as a matter of legislative grace, but as constitutionally mandated under the takings clause," id. at 42. Indeed, Epstein argued that "strict 
United States, ${ }^{129}$ for example, the Court held that no taking occurred when a pier was damaged as a result of the government's blasting of the adjacent riverbed. Justice Holmes, writing for the Court, stated that there might have been a taking if the government had deliberately inflicted the damage. ${ }^{130}$ However, "this [was] an ordinary case of incidental damage which if inflicted by a private imdividual miglit be a tort but which could be nothing else. In such cases there is no remedy agaimst the Umited States." 131 Similarly, the Court in Sanguinetti v. United States, ${ }^{132}$ citing Keokuk, stated that no taking occurred because the flooding of the claimant's land was not "within the contemplation of or reasonably to be anticipated by the Government. If the case were one against a private individual, his liability, if any, would be in tort."133

Not only has the Court distinguished unintentional governmental torts from takings, but it has actually articulated an intent requirement in a number of takings cases. ${ }^{134}$ In Sanguinetti, for exainple, a landowner

liability" should be the rule. He noted that the takings clause "refers to property taken, not property taken negligently or deliberately." Id. at 40.

I do not attempt in this Article to justify the doctrine of sovereign immunity on a normative basis. I contend that, as a descriptive matter, takings must involve intentional deprivations of property because otherwise many governmental actions that presently could only give rise to tort suits would be regarded as takings.

129. 260 U.S. 125 (1922).

130. Id. at 126. Not only was the damage not desired by the government in Keokuk, but it seems that the damage was not substantially certain to follow from the government's action. The Court stated that "[t]he work was done in the usual way and with more than ordinary care; but by the action of the water driven upon the pier by the blast, and possibly by the concussions of the blasts themselves, portions of the pier fell into the river and some damage was inficted." Id.

131. Id. at 127. The Federal Tort Clains Act, ch. 753, tit. 4, 60 Stat. 842 (currently codified in scattered sections of 28 U.S.C.), had not been enacted at the time Keokuk was decided.

132. 264 U.S. 146 (1924).

133. Id. at 150 (citing Keokuk, 260 U.S. at 125).

Along similar lines, the Court of Claims stated in Columbia Basin Orchard v. United States, 132 F. Supp. 707 (Ct. Cl. 1955):

[I]n no case has the Supreme Court ever indicated that an accidental or negligent impairment of the value of property constitutes a taking. They have never departed from the rule that there must have been an intent on the part of the Government to appropriate the property to the use of the public, or to deprive the owner of the beneficial use of it for the benefit of the public. An accidental or negligent impairment of the value of property is not a taking, but, at most, a tort ....

Id. at 710. More recently, the Seventh Circuit stated: "Accidental, unimtended injuries inflicted by governmental actors are treated as torts, not takings. And torts are compensable only to the extent the Federal Tort Claims Act permits." In re Chicago, M. St. P. \& P.R.R., 799 F.2d 317, 326 (7th Cir. 1986), cert. denied, 481 U.S. 1068 (1987).

134. Although the Court has not referred to an intent requirement in its more recent takings decisions, lower courts have done so. See supra note 133. Moreover, in recent years the Court has explicitly recognized an intent requirement in cases involving the deprivation of property without procedural due process. The Court stated in Daniels v. Williams, 474 U.S. 327 (1986): "[T]he Due Process Clause is simply not implicated by a negligent act of an official causing unintended loss of or injury to life, liberty, or property." Id. at 328 (emphasis in original); accord Davidson v. Cannon, 474 U.S. 344, 347-48 (1986). The Court rcasoned in Daniels that the due process clause was not designed to be " 'a font of tort law," " 474 U.S. at 332 (quoting Paul v. Davis, 424 U.S. 693, 701 
argued that the government had committed a taking by constructing a canal that caused flooding of his land. One reason the Court found no taking was that

[i]t was not shown, either directly or inferentially, that the Government or any of its officers, in the preparation of the plans or in the construction of the canal, had any intention to thereby flood any of the land here involved or had any reason to expect that such result would follow. ${ }^{135}$

The Court articulated a similar intent requirement in an earlier case, Portsmouth Harbor Land \& Hotel Co. v. United States. ${ }^{136}$ Again, the case involved physical action by the government that allegedly had the effect of depriving the claimants of certain economically valuable uses of their land. The claimants argued that a taking occurred when the government prevented them from using the land as a summer resort by installing a gun battery at a nearby fort and periodically firing guns over the claimants' land, frightening the public off the premises. The Court had found against the claimants in two prior cases, ${ }^{137}$ stating that occasional firings of the guns did not estabhish an intent to deprive the claimants of the profitable use of their property. When faced with the third case, however, the Court concluded that, given the continuing nature of the government's action, a trier of fact could conclude that the interference was intentional. ${ }^{138}$

(1976)), but rather was designed to protect the individual against arbitrary or oppressive government action. Similarly, one could say that the takings clause is not implicated in the case of an unintentional deprivation of property. Otherwise, the takings clause could be used to seek monetary compensation for a wide range of governmental torts.

135. Sanguinetti, 264 U.S. at 147-48.

136. 260 U.S. 327 (1922).

137. See Peabody v. United States, 231 U.S. 530 (1913); Portsmouth Harbor Land \& Hotel Co. v. United States, 250 U.S. 1 (1919).

138. The Court remanded the case to the Court of Claims to determine whether the firings could still be explained as "only occasional torts" or whether the evidence established an intent on the part of the government to make use of the claimants' property. Portsmouth Harbor, 260 U.S. at 330. The Court further stated: "[E]ven when the intent thus to make use of the claimants' property is not admitted, while a single act may not be enough, a continuance of them in sufficient number and for a sufficient time may prove it." Id. at 329-30. In context, the Court seemed to be saying that the interference was "intentional" if the government knew that it was interfering with the claimants' profitable use of their land, even if the government did not affirmatively desire that result.

The dissent in Portsmouth Harbor argued that a taking can occur only if the government intends to commit a taking, and in this case "the officers of the Government in doing what they did, had no intention of subjecting it to any liability." 260 U.S. at 332 (Brandeis, J., dissenting). The majority evidently rejected this view, since it stated: "If the acts amounted to a taking, without assertion of an adverse right, a contract [to pay] would be implied whether it was thought of or not." Id. at 330.

Relying on Portsmouth Harbor, the Court again referred to an intent requirement in Hurley v. Kincaid, 285 U.S. 95 (1932). In Hurley, a landowner sought to enjoin a flood control project that he claimed would subject his land to periodic flooding and thus would effect a taking. Citing Portsmouth Harbor, the Court stated that it assumed that the "adoption by Congress of a plan of flood control which involves an intentional, additional, occasional flooding of claimant's land constitutes a taking of it-as soon as the Government begins to carry out the project authorized." 
It appears, then, that the Court's takings decisions can best be explained by saying that a taking occurs only when the government "intentionally" deprives $A$ of her property, when the term "intent" is used as defined by William Prosser in Handbook of The Law of Torts:

Intent . . . is broader than a desire to bring about physical results. It must extend not only to those consequences which are desired, but also to those which the actor believes are substantially certain to follow from what he does. ... [W] here a reasonable man in the [actor's] position would beheve that a particular result was substantially certain to follow, he will be dealt with . . . as though he had intended it. ${ }^{139}$

Thus, the intent requirement is met if the government made a deliberate decision to act in a manner that would be substantially certain to force $A$ to give up lier property, even if that impact on $A$ was not affirmatively desired. ${ }^{140}$

Articulating an intent requirement helps provide a more coinplete description of when the Court will find a compensable taking. It also helps resolve an issue that has troubled lower courts and commentators since United States $v$. Causby ${ }^{141}$ was decided-the question of whether fliglits that do not pass directly over the claimant's land can effect a taking.

In Causby, the Court lield that a taking occurred when the government inade frequent low fliglits over the claimants' land, preventing them from using the land as a chicken farm. ${ }^{142}$ The Court stressed that the government had pliysically invaded the airspace directly above the claimants' land. ${ }^{143}$ The Court said that in Causby, as in Portsmouth Harbor,

Id. at 103-04 (citing Portsmouth Harbor, 260 U.S. at 329) (emphasis added). The Court denied injunctive relief, however, since the landowner could sue for just compensation. Id. at 104 .

139. W. Prosser, HandBooK OF The LAW OF TORTS \$ 8, at 31-32 (4th ed. 1971).

140. One could not explain the Court's takings decisions by defining "intent" more narrowly, stating that a taking can occur only if the government desires to deprive $A$ of her property. The Court often finds a taking in cases in which the impact of the government's action on the claimant was not desired, although it was entirely predictable. For example, the government might build a dam, knowing that the dam would cause flooding of $A$ 's land, but not affirmatively desiring that result. See, e.g., Jacobs v. United States, 290 U.S. 13, 16 (1933) (finding a taking in a case in which "[t]he Government contemplated the flowage of the lands" as a result of the construction of a dam, and the "intermittent overflows... impaired the use of the lands for agricultural purposes"). Or the government might make frequent low flights over $A$ 's home, knowing that these flights would prevent $A$ from using the land for certain purposes, but not affirmatively desiring that result. See, e.g., United States v. Causby, 328 U.S. 256 (1946).

141. 328 U.S. 256 (1946).

142. The Court described the impact of the overflights, stating:

[The planes] come close enough at times to appear barely to miss the tops of the trees and at times so close to the tops of the trees as to blow the old leaves off. The noise is startling. And at night the glare from the planes brightly lights up the place. As a result of the noise, [the claimants] had to give up their chicken business. As many as six to ten of their chickens were killed in one day by flying into the walls from fright. Id. at 259.

143. Although the Supreme Court did not articulate an intent requirement in Causby, on 
there was a "direct invasion of [the claimants'] domain." 144 In light of the Court's emphasis on the physical invasion of the claimants' airspace in Causby, it is not surprising that many lower courts subsequently concluded that direct overflights are necessary to establish a taking in a case like Causby. ${ }^{145}$ These courts would find no taking if the flights were over adjacent land, even if those flights were substantially certain to, and did in fact, interfere with the claimant's use of her land. A number of courts $^{146}$ and many commentators ${ }^{147}$ concluded that this was an absurd result. One court remarked: "We are unable to accept the premise that

remand the Court of Claims assumed that such a requirement existed. The lower court held that the claimants should be compensated for the chickens that were killed as a result of the overflights, stating:

We see no difference in the destruction of personal property and real property, where in either case the owner is deprived of its use, not by a negligent act, but as the natural consequence of the deliberate, intended exercise of an asserted power. In each case there is a taking for which the Constitution requires just compensation.

Causby v. United States, 75 F. Supp. 262, 264 (Ct. Cl. 1948) (emphasis added).

144. 328 U.S. at 265-66.

In Loretto v. Teleprompter Manhattan CATV Corp., 458 U.S. 419 (1982), the Court continued to describe Causby as a case in which a taking occurred because the government had physically invaded the claimant's airspace. The Loretto Court emphasized that the flights in Causby were "immediately above" the claimant's land, $i d$. at 430 , and thus constituted a " 'direct invasion of [the claimant's] domain." " Id. at 431 (quoting Causby, 328 U.S. at 265-66). Thus, the Court apparently assumed that the key to the case was the government's intrusion into a defined geographic area.

145. See, e.g., Batten v. United States, 306 F.2d 580, 584 (10th Cir. 1962) ("In Causby, Griggs, and a number of lower court decisions ... there were regular flights over the property. Absent such physieal invasion recovery has been uniformly denied."), cert. denied, 371 U.S. 955 (1963); Avery v. United States, 330 F.2d 640, 645 (Ct. Cl. 1964) (no taking occurred with respect to parcels where there was "no actual invasion of the airspace over these plaintiffs' properties"); Leavell v. United States, 234 F. Supp. 734, 739 (E.D.S.C. 1964) ("Although plaintiff's property was located in an area of major noise, there was no actual invasion of her property rights by overflights or otherwise" and thus under the rule almounced in Batten, no taking occurred.).

146. See, e.g., Alevizos v. Metropolitan Airports Comm'n, 298 Minn. 471, 216 N.W.2d 651 (1974) (direct overflights are not required to establish that property has been "taken, destroyed or damaged" under the state constitution); Martin v. Port of Seattle, 64 Wash. 2d 309, 316-18, 391 P.2d $540,545-46$ (1964) (direct overflights are not required to establish a "taking or damaging" under the state constitution, and the U.S. Supreme Court would be unlikely to hold that direct overflights are required to establish a taking under the federal constitution), cert. denied, 379 U.S. 989 (1965).

147. See, eg., B. ACKerman, supra note 66, at 258; Sax, Takings and the Police Power, 74 YALE L.J. 36, 37 (1964) [hereinafter Sax I]; Dunham, supra note 56, at 87-88.

In Takings and the Police Power, Joseph Sax stated that the airport noise cases should not turn on a "formalistic quibble" over whether the planes "physically penetrated that segment of air directly above the claimant's land." Sax I, supra, at 37. Yet he did not argue that a taking involves an "intentional" deprivation of property, and that intent can be shown without a direct overfight. Rather, Sax explained the overflight cases by saying that a taking occurs whenever an individual "sustains a detrinient to legally acquired existing economic values as a consequence of government activity which enhances the economic value of some governmental enterprise." Id. at 67 . No taking occurs, however, when the government is acting in its "arbitral" capacity, "resol[ving] conflict within the private sector of society." Id. In the overflight cases, Sax argued that the right to disturb neighboring landowners is a "valuable addition to the assets of the enterprise" if a private enterpriser would have to pay for this right under property or tort law. Id. at 37. Given this definition of government acting in its "enterprise" capacity, it is difficult to see why a taking would not occur whenever the government caused economic harm by acting in a inanner that would be a tort if 
recovery for interference with the use of land should depend upon anything as irrelevant as whether the wing tip of the aircraft passes through soine fraction of an inch of the airspace directly above the plaintiff's land." "148

Under the principles of intent articulated in this Article, proof of direct overflights would not be required to establish a taking. The property at issue in an overflight case would be the claimant's freedom to use her land in an economically valuable inanner. Even if the flights were not directly over her land, the clainant could still show that the governinent's action was substantially certain to interfere with the profitable use of her land. Thus, she could establish that the government had intentionally deprived her of her property even if no direct overflight occurred. ${ }^{149}$

\section{IV \\ MORAL JUSTIFICATION}

\section{A. Overview}

Assuming that the government intentionally forced $A$ to give up her property, how does one determine whether that deprivation of property constituted a coinpensable taking? The takings cases can best be explained by saying that whether a coinpensable taking occurs depends on whether the government is preventing or punishing wrongdoing by $A$. If the government says, "You unust give up your property because it would be wrong not to," the governinent is depriving $A$ of her property to prevent wrongdoing. ${ }^{150}$ If it says, "You inust give up your property because you have acted wrongfully," the governinent is depriving $A$ of her property to pumish wrongdoing. So long as the judgment of wrongdoing is reasonable, fairness does not require the payinent of coinpensation. ${ }^{151}$ But the governinent inust compensate $A$ if it simply says, "We want your property because it would promote the coinmon good."152

committed by a private party. Yet, as discussed at supra text accompanying notes $128-33$, this is not the law.

148. Martin v. Port of Seattle, 64 Wash. $2 \mathrm{~d}$ at 316,391 P.2d at 545.

149. Such a deprivation would constitute a taking so long as the government was not preventing or punishing wrongdoing by the claimant. See the discussion of Causby at infra text accompanying notes 494-95.

150. For example, no taking occurs when the government requires $A$ to pay compensatory damages to $B$ for committing a tort. Nor does a taking occur when the government prohibits $A$ from using her land in a manner that would pose a health risk to the community.

151. A taking is also established in the rare case where the claimant proves that the government actually was not seeking to prevent or punish wrongdoing, although it purported to be doing so. See infra notes 207-10 and accompanying text.

152. This statement assumes that the mere fact that the government has concluded that a transfer of $A$ 's property to the government or a third party would promote the common good, does not by itself establish that it would be considered wrong of $A$ not to give up her property. One might 
The public use requirement of the takings clause demands at a minimum that the government be acting to promote the common good. ${ }^{153}$ But even if the deprivation of property benefits the public, a compensable taking may occur. For example, a taking would occur if the government zoned $A$ 's land for public park use only. ${ }^{154}$ Althougli the public would benefit from usimg the land as a public park, the lawmakers could not reasonably believe that it would be considered wrong of $A$ not to donate her land to the government for that purpose.

As slown more fully below, the takings cases can best be explained by reference to societal judgments of wrongdoing. The reviewing court asks wliether the lawmakers reasonably believed that the people of their jurisdiction would consider $A$ 's conduct to be wrongful. ${ }^{155}$ Consider, for

argue that $A$ should be considered culpable on that basis alone. But that judgment is not widely shared in our society. As shown in this Article, the takings cases can best be understood in light of societal judgments of wrongdoing.

The principles offered in this Article are designed to account for the results in the Court's takings decisions and for generally accepted propositions as to when a taking occurs. I have not attempted to answer on a purely normative basis the question of when we should conclude that a compensable taking of property has occurred. See supra text accompanying note 20. I do find the inoral justification principle appealing, however, for it prevents the majority from requiring the minority to give up their property without compensation simply to benefit the majority, yet it does not require the payment of compensation in circumstances where the majority is enforcing judgments of right and wrong. There are, of course, many normative questions that could be raised regarding the inoral justification principle offered in this Article. One is whether compensation should be denied when the judgment of wrongdoing is as weak as it is in many cases in which no taking has been found. Another is whether "wrongdoing" should be measured according to generally held societal notions of wrongdoing, or whether some other standard of right and wrong should be employed. These questions, however, are beyond the scope of this Article.

153. The Court has equated the public use requirement with the minimum rationality requirement of substantive due process. Hawaii Hous. Auth. v. Midkiff, 467 U.S. 229, 241 (1984). As I intend to discuss more fully in a subsequent article, if the public use standard is equivalent to the substantive due process standard, then it not only requires the government to use rational means to further a legitimate public purpose, but it also prohibits the government from acting so unfairly that its action would be considered "arbitrary."

154. Cf. Nollan v. California Coastal Comm'n, 483 U.S. 825, 837 (1987) ("Had California simply required the Nollans to make an easement across their beachfront available to the public on a perinanent basis ... we have no doubt there would have been a taking."); Fred F. French Inv. Co. v. City of New York, 39 N.Y.2d 587, 350 N.E.2d 381, 385 N.Y.S.2d 5 (1976) (ordinance rezoning two private parks for public park use held to be a violation of substantive due process, on the theory that regulation that goes "too far" (as in Pennsylvania Coal Co. v. Mahon, 260 U.S. 393 (1922)) should be regarded as a violation of substantive due process rather than a taking), cert. denied and appeal dismissed, 429 U.S. 990 (1976); City of Plainfield v. Borough of Middlesex, 69 N.J. Super. 136, 173 A.2d 785 (Super. Ct. Law Div. 1961) (zoning ordinance that limited plaintiff' use of their land to use either for a school or for public parks and playgrounds, held to effect a taking).

155. This Article uses the phrase "societal judgment of wrongdoing" in much the same manner that Melvin Eisenberg uses the term "social inorality" in The Nature of the Common Law. Eisenberg defines "social morality" as

moral standards that claim to be rooted in aspirations for the community as a whole, and that on the basis of an appropriate inethodology, can fairly be said to have substantial support in the community, can be derived from norms that have sucli support, or appear as if they would have such support. 
example, Mugler v. Kansas, ${ }^{156}$ where the State of Kansas prohibited the manufacture of alcohohc beverages, causing serious economic losses to the claimant, who owned a brewery. The Court held that no taking occurred, stating that the challenged law represented the judgment "of the people [of Kansas] as thus expressed by their chosen representatives" that the manufacture of alcohohc beverages should be prohibited "to guard the community agamst the evils attending the excessive use of such liquors." 157 That the law represented the inoral judgment of the people of Kansas at that time was sufficient to defeat the brewery owner's takings claim. ${ }^{158}$

This assessnient of the takings cases assumes that the Court views lawmaking as an expression of public values, includimg values of right and wrong, and not simply as a product of competing interest groups exerting power to obtain their desired ends. ${ }^{159}$ If the Court adopted the

M. Eisenberg, The Nature of the Common Law 15 (1988).

Eisenberg states that "[t]he cominon law is heavily concerned with the intertwined concepts of injuries and rights, and it is morality that largely shapes our perceptions of what constitutes injuries and rights." Id. Moreover, the noral norms that the courts should and generally do employ in developing the coininon law are those of social inorality. Thus, Eisenberg argues that in common law adjudication, the judge as lawinaker is atteinpting to determine the public's inoral values. Those values can be derived from a number of sources, including the judge's own observations. Eisenberg says:

Where the moral norms to be derived froin official or unofficial sources are insufficiently specific or not directly applicable, a judge inay rely on his own judgment, as a participantobserver, concerning what norms appear as if they would have the requisite social support, provided he believes-or has no reason not to believe-that his judgment would be widely shared.

Id. at 17 .

Eisenberg recognizes that soine commentators (including John Hart Ely) have asserted that those who believe in social morality, when asked what it incans, provide responses that are either vacuous or so abstract as to admit of any interpretation. He responds that "this argument is contradicted by experience. Moral norms such as 'promises should be kept' and 'lying is wrong' are neither vacuous nor susceptible to any interpretation." Id. at 21. Eisenberg acknowledges that it is not always easy to determine what the coininunity's inoral values are, but states that "we can often reach a pretty firm sense of what most people would regard as fair in a given case." Id.

If one accepts both Eisenberg's account of the common law and this Article's account of the takings clause, one can sec why courts generally are not viewed as committing takings when they create and apply coininon law rules that require private parties to give up economically valuable resources. (For example, a court might require $A$ to pay dainages for negligently inflicting a personal mjury on $B$.) In applying these coinmon law rules, the governinent is intentionally forcing $A$ to give up her property because the lawnaker (the court) reasonably believes that the public would consider it wrong of her not to do so.

156. 123 U.S. 623 (1887).

157. Id. at 662 .

158. As discussed below, judgments of wrongdoing change over time and vary froin one jurisdiction to the next. See infra text accompanying notes 242-62.

159. Cass Sunstein has coininented:

Under soine theories of legislation, the whole enterprise of government consists of efforts by various groups to [assemble the raw political power to obtain what they desire]. . . . Modern pluralism, for example, depends in large part on the idea that coinpeting groups struggle, in a largely unprincipled fashion, to obtain a share of the pie.

Sunstein, Naked Preferences and the Constitution, 84 CoLuM. L. REV. 1689, 1695 (1984) [hereinaf- 
latter view, it would consider it commonplace for legislatures to enact laws depriving private parties of their property without making any judginent that the deprivation was inorally justified. Under that view of the legislative process, the principles I propose in this Article would fail to provide a basis for identifying a fairly small group of cases in which a deprivation of property constitutes a coinpensable taking.

Although my approach assunnes that the Court is taking a "public values" view of lawinaking, this Article differs from Cass Sunstein's articles on public values ${ }^{160}$ because I focus on whether a particular type of public value guides lawmakers' decisions. The issue is not simply whether a law reflects public values, but whether it reflects the public's views on riglit and wrong. Even if a law reflects public values (and thus is not a "naked preference," in Sunstein's terms), ${ }^{161}$ a taking may still occur. If the lawmakers only inade a judgment that giving $A$ 's property to $B$ or to the governinent would proinote the common good, the law could reflect public values, and still effect a taking. ${ }^{162}$

ter Sunstein, Naked Preferences]. Similarly, Frank Michelman has contrasted what he terms a "market model" of lawmaking with a "public-interest" model:

In the economic or public choice model ... [t] the legislature is conceived as a marketlike arena in which votes instead of money are the medium of exchange. . . . Legislators do not deliberate towards goals, they dicker towards terms. ... There is no public or general or social interest, there are only concatenations of particular interests or private preferences. ...

... In [the] public-interest model the legislature is regarded as a forum for identifying or defining, and acting towards [public or objective values and ends for human action]. . . . Majority rule is experienced . . a as a device for filtering the reasonable from the unreasonable, the persuasive from the unpersuasive, the right from the wrong and the good from the bad.

Michelman, Political Markets and Community Self-Determination: Competing Judicial Models of Local Government Legitimacy, 53 IND. L.J. 145, 148-49 (1977-78). Michelman commented that although the public-interest model may seem sentimental, he doubted that it was less real than the market model "as a description of our actual way of experiencing and interpreting our political life [or] as a description of the way judges perceive that life." Id. at 149-50.

160. See, e.g., Sunstein, Interest Groups in American Public Law, 38 STAN. L. Rev. 29 (1985); Sunstein, Naked Preferences, supra note 159.

161. Sunstein has defined a "naked preference" as "the distribution of resources or opportunities to one group rather than another solely on the ground that those favored have exercised the raw political power to obtain what they want," and a "public value" as "any justification for government action that goes beyond the exercise of raw political power." Sunstein, Naked Preferences, supra note 159, at 1689, 1694.

162. In Naked Preferences and the Constitution, Sunstein appropriately equated the "public use" requirement of the takings clause with the requirement that government action be "justifiable by reference to some public value." Sunstein, Naked Preferences, supra note 159, at 1724. Yet when he considered the issue of when a compensable "taking" occurs, Sunstein failed to draw a line between public values regarding right and wrong, and other public values. Sunstein came very close to saying that, unless a physical invasion is involved, no taking occurs if the challenged law meets the public use test:

At least in the absence of a physical taking, if a statute [does not reflect a naked preference] ... there is generally no violation of the Takings Clause, even if no compensation is paid. ...

$\ldots$

... If the state physically invades a person's property and transfers it to another, 
Some may be skeptical of the notion that a taking occurs unless a "judgment of wrongdoing" has been made, because this suggests to them a strong judgment of condemnation. However, I use the phrase "judgment of wrongdoing" broadly, to cover moral judgments ranging from strong judgments of condemnation to very weak ones. ${ }^{163}$ A strong judgment of condemnation would be made if $A$ committed a serious crime. A less severe judgment would be made if $A$ breached a contract. Perhaps an even less severe judgment of condemnation would be made if $A$ acted in a manner that was considered a nuisance. In each case, however, $A$ is viewed as having acted wrongfully, not simply as having failed to promote the common good. ${ }^{164}$

compensation is required even if a public use can be shown. This requirement is best understood as a rights constraint, for the government's motivation is irrelevant. In this respect, the Eminent Domain Clause is not merely a prohibition of naked preferences.

Id. at 1725-26. Sunstein acknowledged that there is "considerable awkwardness" in applying the saine standard to determine whether the public use test is met and whether a taking occurs (apart from physical invasion cases). Id. at $1725 \mathrm{n} .174$. He also noted that in some physical invasion cases the Court has held that no taking occurred. Id. at $1726 \mathrm{n} .183$.

Logically, one cannot apply the same standard to decide the public use issue and to decide whether compensation must be paid. Nor is physical invasion the critical issue. Rather, I argue in this Article that the Court's takings decisions can best be explained by saying that the public use test is met if the government is seeking to implement public values, while whether a taking occurs depends upon whether the government is seeking to implement public values regarding right or wrong. Thus, the "government's motivation" is relevant in determining whether compensation inust be paid.

163. In this Article, I use the phrases "judgment of blaineworthiness" and "moral justification" as synonyms for "judgment of wrongdoing."

164. Similarly, Frank Michelman has argued that no taking occurs when the government prohibits "theft-like" conduct, including conduct that may be labeled a "nuisance." Michelman, Property, Utility and Fairness: Comments on the Ethical Foundations of 'Just Compensation' Law, 80 HARV. L. ReV. 1165 (1967). Michelman began with the generally accepted proposition that no taking occurs when the government requires a thief to give back the thing he has stolen, and then stated: "The case is not essentially different if I own a residence in a pleasant neighborhood and you open a brickworks nearby. ... Society, by closing the brickworks, simply makes you give back the welfare you grabbed .... The whole point of society's intervention negates any claim to compensation." Id. at 1236.

Contrary to my position, Michelman did not argue that a taking occurs whenever the government intentionally deprives $A$ of property and is not seeking to prevent or punish wrongdoing. Instead, Michelman asserted that no compensation issue even arises when "social action ... merely corrects prior, unilaterally determmed redistributions ['theft-like' conduct], or brings a deliberate gainble to its dénouement." Id. at 1239. Focusing on the remaining cases, he argued that fairness would not require the payment of compensation "as long as the disappointed claimant ought to be able to appreciate how such decisions might fit into a consistent practicc which holds forth a lesser long-rnn risk to people like him than would any consistent practice which is naturally suggested by the opposite decision." Id. at 1223. Yet Michelman did not offer this as a doctrine to be applied by the courts. Indeed, he expressed doubt that judges would be able to apply this standard. Id. at 1171, 1248-51.

Brnce Ackerman also focused on moral judgments when he argued in Private Property and the Constitution that the takings cases can best be explained by saying that a taking occurs when the state takes away the claimant's property without "Ordmary justification." B. ACKERMAN, supra note 66, at 150-52. No compensation is due when the government prevents the claimant from "[taking] actions that, as a well-socialized [person], he should know are unduly harmful to others... 
In many cases, a given type of conduct is considered wrongful only in a particular location or only under certain circumstances. For example, a factory in a residential neighborhood may be viewed as a nuisance, although it would be readily accepted in an industrial neighborhood. The judgment is merely that it is wrong to act in this manner in this particular location. ${ }^{165}$ Nevertheless, the person committing the nuisance is viewed as wrongfully interfering with her neighbors' enjoyment of their land. ${ }^{166}$

My thesis does not depend on establishing how judgments of wrongdoing are made. It does, however, depend on the assumption that people in our society constantly make judgments as to who is in the wrong in conflicts regarding economically valuable resources. I argue that the results reached by the Court in its takings decisions are generally consistent with these societal judgments of wrongdoing.

One possible response to this thesis is that im many takings cases there is no rational basis for saying that one party is the wrongdoer. For example, if $A$ wants to build a factory in a predominantly single-family area, and those who hive in nearby hoines object, one might argue that this shows only that the desires of $A$ and the desires of her neighbors conflict. Who is to say that $A$ is at fault? Joseph Sax argued in Takings and the Police Power ${ }^{167}$ that neither takings cases nor nuisance law can be viewed as depending on judgments of blame or wrongdoing. According to Sax, nuisance cases simply involve two conflicting land uses, neither of thein in the wrong. ${ }^{168}$ Moreover, he asserted that the same conclusion could be drawn in numerous other contexts:

The list could be extended indefinitely. When a truck is ordered to use inud-guards to prevent splashing other road users, is this non-compensable because the trucker has caused the evil-that is, mud-splashing? Or have other drivers caused the evil by glutting the highways? It is just as

and hence wrong to do with his thing." Id. at 98-99. However, as previously discussed, see supra text accompanying notes $66,71,73 \& 75$, Ackerman defined "property" in a manner that differs significantly from the definition offered here. Moreover, Ackerman focused on cases in which the government was prohibiting harmful uses of tangible things.

165. As the Supreme Court explained in Village of Euclid v. Ambler Realty Co., 272 U.S. 365 (1926), "[a] nuisance may be merely a right thing in the wrong place,-like a pig in the parlor instead of the barnyard." Id. at 388 .

166. In discussing nuisances and "noxious uses," the Court has often equated a nuisance with wrongful behavior. In Mugler v. Kansas, 123 U.S. 623 (1887), for example, the court contrasted a "nuisance" with an "innocent" use of property, id. at 669, and relied on the "fundamental principle that every one shall so use his own [property] as not to wrong and injure another.'" Id. at 667 (quoting Fertilizing Co. v. Hyde Park, 97 U.S. 659, 667 (1878)); see also infra note 173; text accompanying notes 503-09.

167. See Sax I, supra note 147.

168. Sax asserted that "it [cannot] be said that a nuisance is a somehow morally culpable use." Id. at 49 n.75. He argued that a nuisance is a "lawful activity" that, as the Court stated in Village of Euclid, is just in the "wrong place." Id. at 49 \& n.75. 
rational to attribute the harm to increased congestion, and thus spread the cost among all road users, as it is to attribute it to the trucker. The same could be said of fire regulations imposed upon all old wooden buildings in a city: has the house owner caused the harm by operating a fire trap; or is the building a fire trap now because others have made the neighborhood a congested one? ${ }^{169}$

The difficulty with this Coasean mode of analysis ${ }^{170}$ is that it is inconsistent with ordmary perceptions of the world. ${ }^{171}$ People generally view the truck splashing mud as causing harm to others, and they generally regard a building that is a "firetrap" as creating an undue risk of harm to others. Similarly, they see the factory spewing out funnes as harming those who hive nearby ${ }^{172}$ In these examples, most people would consider the conduct to be wrongful or blameworthy. Given these widely shared views, we are not concerned that fairness may require

169. Id. at 50. In Takings, Private Property and Public Rights, 81 YALE L.J. 149 (1971) [hereinafter Sax II], Sax again asserted that the takings decisions cannot be viewed as resting on a moral basis. He again argued that when two land uses conflict, neither can be viewed as wrong. For example, he stated that just as a factory affects others by spewing forth sinoke, "us[ing] land in a way that deinands ... the absence of smoke on one's land is similarly to burden the common in air ... and cannot be a matter of constitutional right." Id. at 162 . Sax expressed the view that so long as the government is seeking to maximize the value of the resource base, it inay exclude the factory froin the residential area or exclude residential uses from the area, and in either case no taking will occur.

170. Although Coase was concerned with questions of efficiency, not moral judgments, the ideas he explored in The Problem of Social Cost, 3 J.L. \& EcoN. 1 (1960), provoked others (including Sax) to question moral judgments that are preinised on the assumption that $A$ should be viewed as having caused harm to $B$. Coase began The Problem of Social Cost by stating:

This paper is concerned with those actions of business firms which have harmful effects on others. The standard exainple is that of a factory the sinoke from which has harmful effects on those oceupying neighbouring properties....

... The question is commonly thought of as one in which $A$ inflicts harm on $B$ and what has to be decided is: how should we restrain $A$ ? But this is wrong. We are dealing with a problem of reciprocal nature. To avoid the harm to $B$ would inflict harm on $A$. The real question that has to be deeided is: shonld $A$ be allowed to harm $B$ or should $B$ be allowed to harm $A$ ?

Id. at 1-2.

171. Robert Ellickson observed in Alternatives to Zoning: Covenants, Nuisance Rules, and Fines as Land Use Controls, 40 U. CHI. L. REV. 681 (1973), that although Coase and others have argued that it cannot be determined who is causing harm to whoin, "[i]n ordinary speech . . . people consistently distinguish 'harms' from 'benefits ...." Id. at 729. For example, Ellickson stated that in a conflict betwecn a commercial use and surrounding single-family residential uses, ordinary people would view the commercial use as the harmful one. Id.

Sinilarly, Epstein questioned Sax's view that in many land-use confiicts one cannot say who is harming whoin. For exainple, Sax argued in Takings, Private Property and Public Rights, that if the Navy were to use a bay for a gunnery range, thereby making the shoreland uminhabitable, one could not say that the Navy was causing harm to the neighboring landowners. Sax II, supra note 169, at 167-69. Epstein remarked that "[t]he land could be said to get in the way of the bullets, as the face gets in the way of the fist." R. EPSTEIN, supra note 28, at 117.

172. As Ackerman remarked of his "Ordinary justification" thesis, "the analysis only requires an appeal to the intuitions of my (presumably) well-socialized colleagues in the law." $B$. ACKERMAN, supra note 66, at 99. Yet he also noted that the Coase Theorem has made a deep impression upon the current generation of law teachers. Id. at 169. 
compensation if the truckdriver is required to stop splashing mud on others, or the owner of the firetrap is required to make the building safer, or the factory is excluded from a residential area. These are easy cases if one takes account of widely shared judgments of wrongdoing, although they might be difficult cases from a Coasean point of view. ${ }^{173}$ If iny thesis is correct, the Court would find it easy to conclude in each case that the regulation did not effect a taking. ${ }^{174}$

Under the principles offered here, a court would rarely find that a governmental deprivation of $A$ 's property constituted a taking, since the government generally would be "preventing or pumishing wrongdoing" when it required $A$ to give up her property. This is true for a number of reasons. First, the term "wrongdoing" is used to describe quite weak judgments of condemnation, as im a nuisance case. Second, the reviewing court would not make an imdependent judgment of whether the public would consider $A$ 's conduct to be blameworthy. Rather, the court would consider whether the lawinakers (or other authorized governmental decisiomnakers) reasonably believed that the public would consider $A$ 's conduct to be blameworthy. ${ }^{175}$ Indeed, the reviewing court would give such great deference to the lawmakers' judgment that one might say that no taking will be found so long as the lawmakers made a plausible determi-

173. My analysis of takings cases assumes that the Court acts in accordance with ordinary perceptions of who is in the wrong, whether or not it expressly justifies its takings decisions in that manner. In fact, the Court has at times made it clear that it does not view conflicts over material resources in Coasean terms. This is apparent in a number of takings decisions in which the Court has spoken in terms of judgments of blame. See infra text accompanying notes 503-09. It can also be seen in cases outside the takings context.

LeRoy Fibre Co. v. Chicago, Milwaukee \& St. Paul Railway, 232 U.S. 340 (1914), for example, involved a conflict between a railroad, whose engines emitted sparks, and the owner of land adjacent to the railroad tracks, who stored flax near the tracks. A fire set by sparks from an engine destroyed the flax, and the landowner blamed the railroad. The Court agreed. Moreover, it rejected the railroad's argument that the landowner was also to blame, since he had used his land in a manner that permitted this incident to occur. The Court stated:

That one's uses of his property may be subject to the servitude of the wrongful use by another of his property seems an anomaly.... It casts upon him the duty of not only using his own property so as not to injure another, but so to use his own property that it may not be injured by the wrongs of another. How far can this subjection be carried?

Id. at 349. One could argue that LeRoy Fibre involved simply a conflict between two parties over the use of material resources, and that neither party could rationally be viewed as the cause of the harm. Yet most people would see the railroad as the cause of the harm, and the Court approached the case in the same manner.

174. Indeed, in Village of Euclid v. Ambler Realty Co., 272 U.S. 365 (1926), the Court upheld a zoning ordinance that excluded industrial uses from residential areas, drawing an analogy to the law of nuisance.

175. In many cases, the authorized governmental decisionmaker is a legislative body. In some cases, however, the decisionmaker is a judge or a governmental agency or official who is authorized to order $A$ to give up her property. In United States v. Caltex, Inc., 344 U.S. 149 (1952), for example, discussed at infra text accompanying notes 182-85, the authorized governmental decisionmaker was General MacArthur, who ordered the destruction of the claimants' oil facilities in the Philippines during World War II. 
nation that the public would consider $A$ 's conduct to be blameworthy. ${ }^{176}$ Moreover, the reviewing court would assume that a judgment of wrongdoing had been made if such a judgment could plausibly have been made, unless the evidence showed that in fact no judgment of wrongdoing had been made. ${ }^{177}$ To find a taking, then, the reviewing court would either have to conclude that no judgment of wrongdoing could plausibly have been inade, or that in fact no judgment of wrongdoing had been made.

\section{B. What Makes the Hard Cases Hard?}

Focusing on the moral justification for depriving $A$ of her property helps explain why some takings cases are easy to resolve, while others are far more troubling. Imagime, for a moment, the vast array of cases im which the government intentionally deprives $A$ of her property, arranged on a spectrum from cases in which the government seeks to prevent or punish behavior that clearly is considered culpable, to cases in which the government clearly is not dealing with blameworthy conduct. When the government is clearly preventing or punishing culpable behavior, it is generally accepted that the deprivation of property does not constitute a compensable taking. For example, no one thinks a taking occurs when the government requires $A$ to pay a fine for committing a crime, to forfeit property used in the commission of a crime, ${ }^{178}$ or to pay damages for

176. Ackerman expressed much the same notion when he stated in Private Property and the Constitution that a "restrained" judge called upon to decide whether the government has taken the claimant's thing without "Ordinary justification" will find a taking "when the legislative action plainly fails to correspond to the dommant pattern of institutionalized expectation." B. ACKERMAN, supra note 66, at 107 (emphasis added).

Epstein, by contrast, argued in Takings that a fairly demanding standard of judicial review should be applied in takings cases. According to Epstein, "What is needed is an imtermediate standard of review ... [as] in Lochner [v. New York, 198 U.S. 45 (1905)]." R. EPSTEIN, supra note 28, at 128. Under Epstein's standard of review, many generally accepted land-use regulations would be considered takings. See discussion at infra note 268 .

177. See infra text accompanying notes 207-10.

178. Here the government is punishing the claimant for wrongdoing. See United States v. U.S. Coin \& Currency, 401 U.S. 715, 718 (1971) (where property is forfeited because the owner of the property used it in the cominission of a crime, liability is clearly based upon a finding of the owner's wrongful conduct, even if the proceeding is formally civil in nature); Kingsley Books, Inc. v. Brown, 354 U.S. 436, 444 (1957) ("[P]rovision for the seizure and destruction of the instruments of ascertained wrongdoing expresses resort to a legal remedy sanctioned by the long history of AngloAmerican law."); Boyd v. United States, 116 U.S. 616, 634 (1886) ("[P]roceedings imstituted for the purpose of declaring the forfeiture of a inan's property by reason of offenses cominitted by him, though they may be civil in form, are in their nature criminal."). But $c f$. Calero-Toledo v. Pearson Yacht Leasing Co., 416 U.S. 663 (1974) (rejecting a takings challenge even where the owner of the property did not himself commit the crime, and explaining that historically the courts have relied on the fiction that the thing itself was guilty of wrongdoing). See the discussion of Calero-Toledo at infra text accompanying notes 405-11. There could also be cases in which the forfeiture was designed to prevent wrongdoing, rather than to punish $A$ for a wrongful act that she had already committed. 
committing a tort. ${ }^{179}$ At the other extreme, if the government clearly is not or could not be making a judgment of blame or culpability, it is generally accepted that the deprivation of property is a taking. One example is an eminent domain proceeding. There, the government does not purport to be punishing $A$ or preventing $A$ from behaving wrongfully. The government's only justification for depriving $A$ of her property is that this would promote the common good. ${ }^{180}$

The cases are more difficult, however, when it is unclear whether the public would consider $A$ 's conduct to be blameworthy. ${ }^{181}$ For example, in United States v. Caltex, Inc., ${ }^{182}$ the claimants were American oil companies that owned facilities in the Philippines in December 1941. Shortly after the attack on Pearl Harbor, General MacArthur ordered the claimants to permit the U.S. Army to destroy these facilities because they were about to fall into enemy hands. The Supreme Court held that the destruction of the facilities was not a taking. Arguably, permitting these facilities to fall into the hands of the Japanese would have been wrong, for it would have been like handimg a weapon to the enemy. ${ }^{183}$ Indeed,

179. Many writers either do not attempt to explain why no taking occurs in these easy cases or give a brief, unsatisfactory explanation. For example, in Takings and the Police Power, Sax commented at the end of the article:

The imposition of a fine in a criminal proceeding, the proceeds of which go into the state's general funds, is conceptually a taking under the formula suggested here. But we recognize a privilege to impose such deprivations in order to promote an important policy .... That such exceptions may be logically inconsistent with other possible cases when a privilege is denied proves only that law must pay some deference to tradition and history, even in derogation of antiseptic rationality.

Sax I, supra note 147, at 75. In iny view, however, recognition that imposing a fine is not a taking is wholly consistent with the principles governing other takings cases. Although the government intentionally deprives someone of property when it imposes a fine, it does so to punish wrongdoing, and thus no taking occurs.

180. See infra notes $194-95$ and accoinpanying text.

181. Note that the terms "wrongdoing" and "blameworthy conduct," as used in this Article, do not refer to a clearly circumscribed category of cases. Compare Epstein's view that no taking occurs if the government is exercising the "police power," but that "[t]he sole function of the police power is to protect individual liberty and private property against all inanifestations of force and fraud." $R$. EPSTE1N, supra note 28, at 112 . There are many circumstances in which Epstein would say there was no "police power justification" for the governinent's action because no force or fraud was involved, while I would say that the government had a plausible moral justification for its action.

182. 344 U.S. 149 (1952).

183. Many years earlier, Justice Bradley had remarked that no taking would occur if the government authorized private property to be taken "to prevent its falling into the hands of an enemy ... or, in virtue of some other inuminent necessity, where the property itself is the cause of the public detriment." Davidson v. New Orleans, 96 U.S. 97, 107 (1877) (Bradley, J., concurring). The majority in Caltex may have viewed this as a case in which the claimants were being prevented fron harming the public, for they analogized Caltex to an earlier case in which the Court had held that no taking occurred when the governinent destroyed a building thought to house the germs of a contagious disease. 344 U.S. at 154.

The majority may also have been influenced by evidence that the Japanese would have destroyed the facilities had the U.S. Government not done so. The dissenting judge in the Court of Claims had argued that no taking occurred, stating in part: 
the majority stated: "[T] he Army's . . . sole objective [was to] destroy[ ] property of strategic value to prevent the enemy from using it to wage war the more successfully. ... [T]his property . . . had become a potential weapon of great significance to the invader. It was destroyed, not appropriated for subsequent use."184 The dissenters, however, contended that the government had simply forced the claimants to give up their facilities to promote the common good: "The property was destroyed, not because it was in the nature of a public nuisance, but because its destruction was necessary to help wm the war. . . . Whenever the Government . . . appropriates [property] for the common good, the public purse, rather than the mdividual, should bear the loss."185

Another takings decision that lias troubled many is Penn Central Transportation Co. v. New York. ${ }^{186}$ The Court found that no taking occurred when the claimants in Penn Central were prohibited, under New York City's Landmarks Preservation Law, from building a modern, highrise office building on top of Grand Central Terminal. On the one liand, there seems to be a growing sentiment that it is wrong to alter dramatically sucli an historically significant structure as Grand Central Terminal. ${ }^{187}$ Yet otliers would say that the claimants in Penn Central were simply being forced to promote the common good. ${ }^{188}$

Miller v. Schoene ${ }^{189}$ is anotlier case that many consider problematic. In Miller, the Court rejected a takings challenge to a statute that made it unlawful to "own, plant or keep alive and standing" on one's premises any red cedar tree tllat liad been determined to be infected witli the commumicable plant disease known as cedar rust, and declaring that any such

\footnotetext{
At [the] time [the facilities were destroyed,] the Japanese were at the outskirts of the city of Manila. There was no hope of saving the property. If the city were further defended, the property would undoubtedly be destroyed. If it fell into the hands of the Japanese it certainly would be destroyed before they gave it up. . . . Any possible value to the plaintiffs was gone....
}

Caltex, Inc. v. United States, 100 F. Supp. 970, 982 (Ct. Cl. 1951) (Jones, C.J., dissenting in part). If indeed there was no hope of ultimately recovering possession of the facilities intact, perhaps an even stronger argument could be made that it would have been wrong of the claimants to allow the facilities to fall to the enemy in usable condition.

184. Caltex, 344 U.S. at 153, 155 (emphasis added).

185. Id. at 156 (Douglas, J., dissenting).

186. 438 U.S. 104 (1978).

187. One might argue that such conduct is like deliberately defacing a masterpiece and thus should be considered wrongful. Cf. CAL. Crv. CoDE $\S$ 987(c)(1) (West Supp. 1989) ("No person, except an artist who owns and possesses a work of fine art which the artist has created, shall intentionally commit, or authorize the intentional commission of, any physieal defacement, mutilation, alteration, or destruction of a work of fine art.").

188. That is, some people would regard this as a case in which the claimants' proposed conduct could not reasonably be regarded as blameworthy. One might argue that this is like forcing the owner of a work of fine art to put it on display free of charge. From this perspective, the law requires the owner of the historically significant building to "do good," rather than preventing her from acting wrongfully.

189. 276 U.S. 272 (1928). 
tree growing within a certain radius of an apple orchard was a "public nuisance" subject to destruction. ${ }^{190}$ Again, one could argue that it would have been wrong of the owners of the cedar trees not to destroy the diseased trees. But one could also argue that the claimants were simply being forced to give up their property to benefit others. ${ }^{191}$

The moral justification principle does not suddenly make these difficult takings cases simple. There will always be borderline cases that cannot be easily resolved. This principle does, however, offer a means of conceptually ordering the cases. By focusing on whether the government's action is designed to prevent or pumish blameworthy behavior, one can see why some takings cases are more troubling than others.

The Court's takings doctrine, on the other hand, does not provide a means of conceptually ordering the cases. The Court often focuses solely on what $A$ lost-how greatly a tangible resource diminished in value, or how significantly the uses of a tangible resource have been linnitedrather than on why the government acted. Yet one cannot explain when a taking occurs simply by considering what $A$ lost. ${ }^{192}$ Moreover, even when the Court focuses on the government's justification for depriving $A$ of her property, it often asks whether the challenged regulation promoted the common good, rather than asking whether the governinent deprived $A$ of her property to prevent or punish wrongdoing by $A$. The government plainly can effect a taking, however, even when it is acting to promote the common good. ${ }^{193}$

\section{Cases in Which the Governmental Decisionmakers Did Not Purport to Be Making a Judgment of Wrongdoing}

There are a number of contexts in which the government intentionally deprives $A$ of her property without expressly or implicitly making a judgment of wrongdoing with respect to her. In such cases, a compensable taking occurs. For example, when the government formally exercises its emment doniain power, the government's justification for requiring $A$ to give up her property is simply that it would promote the common good. ${ }^{194}$ If the government condemns $A$ 's land to build a highway, for

190. Id. at 277-80.

191. Miller $v$. Schoene is discussed more fully at infra text accompanying notes 395-404.

192. See Peterson I, supra note 4, at 1352-56.

193. See id. at 1357-58.

194. When the government states that it is exercising its "eminent domain power," the government is saying that it is exercising its sovereign power to require $A$ to give up her property for a public use. See San Diego Gas \& Elec. Co. v. City of San Diego, 450 U.S. 621,638 n.2 (1981) (Brennan, J., dissenting) ("'Eminent domain' is the 'power of the sovereign to take property for public use without the owner's consent." " (quoting 6 J. SACKMAN, Nichols' LAW OF EMINENT Domain § 1.11, at 1-7 (rev. 3d ed. 1980))); Boom Co. v. Patterson, 98 U.S. 403, 406 (1878) ("The right of eminent domain, that is, the right to take private property for public uses, appertains to every independent government. It requires no constitutional recognition; it is an attribute of 
example, the government is not asserting that it would be wrong of $A$ not to donate the land to the government, nor is it asserting that the land must be forfeited to pumsh $A$ for some wrongful act. The government is simply asserting that the land will be used in a manner that will benefit the public. ${ }^{195}$

Similarly, in many "physical invasion" cases, the government does not purport to be preventing or punishing wrongdoing by $A$. Suppose the government determines that a new dam would benefit the public and therefore decides to build one, knowing that the dam's construction will result in the permanent fiooding of $A$ 's land. No eminent domain proceedings are instituted, the dain is built, $A$ 's land is flooded, and $A$ alleges that a taking occurred. Is compensation due? Here the government intentionally deprived $A$ of the freedom to use her land in an economically valuable manner, thus depriving her of her property, and the governmental decisionmakers plainly did not make a judgment of wrongdoing with respect to $A$. The government simply took $A$ 's property to promote the cominon good. Thus, a compensable taking occurred. ${ }^{196}$

The government may also enact a law that requires $A$ to give up certain property, but make no explicit or inphicit finding that it would be wrong of $A$ not to give up the property, or that $A$ is being punished for wrongful behavior. In effect, the lawmakers sinply assert that they are attempting to benefit the public generally or some segment of the public. In Lynch v. United States, ${ }^{197}$ for example, the clainants argued that a taking occurred when Congress enacted a law reneging on disability and

sovereignty."). Statutes authorizing formal eminent domain proceedings provide that the government must be acting to promote the common good. See, e.g., 40 U.S.C. $\S 257$ (1982) ("In every case in which the ... officer of the Government has been . . . authorized to procure real estate for ... public uses, he may acquire the same for the United States by condemnation, under judicial process, whenever in his opimion it is necessary or advantageous to the Government to do so.").

195. Ackerman remarked in Private Property and the Constitution:

[In] the standard highway building case, [the government] takes [the claimant's] things away from him ... not because he has been acting badly but because his land is particularly flat and therefore relatively cheap for road building. . . . Laymen in their daily lives do not generally eondemn each other simply for owning flat land . . .

B. ACKERMAN, supra note 66 , at 152.

Although members of the public generally would not regard $A$ as "acting badly" because he failed to donate his land to be used for a highway, they would regard him as "acting badly" if he failed to pay his ineome taxes. As discussed at infra text accompanying notes 345-85, a tax on one's income has come to be regarded as a "civic obligation." Like other civic obligations, the burden is broadly distributed.

196. These physical invasion cases should be distinguished from cases in which the government authorizes a physical invasion of $A$ 's land (or other tangible economically valuable resource), and does purport to be preventing or punishing wrongful behavior. For example, when the government requires $A$ to forfeit a tangible thing used in the commissiou of a crime, it is punishing $A$ for conduct that is considered wrongful.

197. 292 U.S. 571 (1934). 
life insurance contracts that the government had issued to veterans under the War Risk Insurance Act. ${ }^{198}$ In passing the law, Congress did not purport to be preventing or punishing blameworthy conduct. Finding a taking, the Court stated:

The [government] does not suggest . . . that there were supervening conditions which authorized Congress to abrogate these contracts in the exercise of the police or any other power. The title of the Act ... repels any such suggestion. ... [ [P]opularly known as the Economy Act, it is entitled an "Act to maintain the credit of the United States."199

The outcoine in Lynch can best be understood by observing that the government sought only to save money; it did not seek to prevent or punish wrongdoing by the claimants. ${ }^{200}$ The finding of a taking in these circuinstances is therefore consistent with, and could be predicted by, the moral justification principle.

\section{Reviewing Purported Judgments of Wrongdoing}

In some cases, the government does not even purport to be inaking a judgment of blameworthiness. ${ }^{201}$ In other cases, the government purports to be making such a judgment, but the judgment of blanieworthiness is so implausible that the Court rejects it. Nollan v. California

198. The property taken in Lynch was a "vested" economically valuable legal right to force the U.S. Government to perform under the insurance contract. See supra text accompanying notes 69 72; infra text accompanying notes 307-12.

199. Lynch, 292 U.S. at 579-80.

200. The Court recently summarized the Lynch decision in Bowen v. Public Agencies Opposed to Social Security Entrapment, 477 U.S. 41 (1986), stating: "[The Court has] held that Congress does not have the power to repudiate its own debts, which constitute 'property' to the lender, simply in order to save money." Id. at 55 (citing Lynch, 292 U.S. at 576-77) (einphasis added).

When the Court stated im Lynch that the government had not suggested that the "police power" justified abrogating these contracts, 292 U.S. at 579-80, the Court apparently meant that the government did not purport to be prohibiting wrongful or blameworthy conduct. The cases the Court cited as involving the "federal police power" included: Hoke v. United States, 227 U.S. 308 (1913), a case involving a federal statute designed to prevent women from being transported across state lines to work as prostitutes; Hipolite Egg Co. v. United States, 220 U.S. 45 (1911), a case involving a federal statute designed to prevent tlie "culpable" conduct of transporting adulterated food products in interstate commerce, $i d$. at 57; and The Lottery Case, 138 U.S. 321 (1903), a case in whicl Congress prohibited the carrying of lottery tickets from one state to another "for the purpose of guarding the people of the United States against the "widespread pestilence of lotteries," id. at 357. Lynch, 292 U.S. at 579 n.7.

If the term "police power" is used to mean the government's power to prevent or punish blameworthy conduct, then no compensable taking occurs when the government is exercising its police power. But the government is often said to be exercising its "police power" when it enacts legislation to promote the common good. See, e.g., Keystone Bituminous Coal Ass'n v. DeBenedictis, 480 U.S. 470, 491 n.20 (1987) (stating that the "'scope of the "public use" requirement of the Takings Clause is "cotermmous with the scope of a sovereign's police powers" ") (quoting Ruckelshaus v. Monsanto, Co., 467 U.S. 986, 1014 (1984) (quoting in turn Hawaii Hons. Auth. v. Midkiff, 467 U.S. 229, 240 (1984))). If tlie term "poliee power" is used in that manner, a taking can occur even when the government is exercising its "police power."

201. See supra notes $194-200$ and accompanying text. 
Coastal Commission ${ }^{202}$ is such a case. In Nollan, the government argued that if the Nollans built a single-family dwelling on their beachfront lot, they would interfere with the public's view of the beach froin the road, thereby reducing the public's desire to use the beach. This harm to the public would be mitigated, it was contended, if the Nollans permitted those who were using the beach to walk across their land. The Court, however, found it impossible to understand low providing lateral beach access would remedy any probleins created by building the house, and suggested that in fact the government was atteinpting to extract a public benefit without paying just compensation. As the Court expressed it, this was not regulation, but extortion. ${ }^{203}$ Thus, the Court's decision in Nollan could be explained by saying that the government purported to have made a judgment that the Nollans would wrongfully harm the public if they built without providimg public access, but the Court found that judgment to be implausible. ${ }^{204}$ In fact, the Court strongly suggested that it considered the proffered justification for the access requirement to be not only implausible, but insmcere. The Court referred to the "made-up purpose of the regulation"205 and to its concern that the government's purpose was actually avoidance of the requirement of paying just compensation. ${ }^{206}$

Under the moral justification principle, a court could find a taking on the ground that the purported judgment of wrongdomg was demonstrably insmcere. The Court came close to making sucli a finding in Nollan. Moreover, in Keystone Bituminous Coal Association $v$. DeBenedictis, ${ }^{207}$ the Court stated that it liad found a taking in Pennsylvania Coal Co. v. Mahon ${ }^{208}$ because, although the lawmakers purported to be protecting the public safety, the actual purpose of the law was to benefit certain private parties. According to the Court, "Pennsylvania Coal imstructs courts to examime the operative provisions of a statute, not just its stated purpose, in assessing its true nature. In

202. 483 U.S. 825 (1987). Nollan is discussed at supra text accompanying notes $57-60$ and 11222.

203. Nollan, 483 U.S. at 837. Nollan is discussed more fully in Peterson I, supra note 4, at 1305$08,1335-41$.

204. This is not to say that the Court explained the case in these terms. Indeed, the Court said that a taking occurred because the exaction did not "substantially advance a legitimate state interest." Nollan, 483 U.S. at 834-42. Yet the exaction directly served the legitimate state interest of obtaining public access to the beach; it simply did so in an unfair manner. The Court came somewhat closer to expressing this notion when it said that there was not a sufficient "nexus" between the exaction and the justifications that might have been offered for entirely prohibiting the Nollans from building. Id. at 837. This statement suggests a concern by the Court that the exaction would not undo the harm to the public that the Nollans allegedly would cause by building.

205. Id. at 839 n.6.

206. Id. at 841 .

207. 480 U.S. $470,483-85$ (1987).

208. 260 U.S. 393 (1922). 
Pennsylvania Coal, that inquiry led the Court to reject the Pennsylvania Legislature's stated purpose . . ."209 This focus on the lawmakers' actual purpose is consistent with cases that find a taking where the claimants prove that lawmakers have downzoned their land to reduce its fair market value in order to acquire it for less in a subsequent eminent domain proceeding. ${ }^{210}$

Ordinarily, the claimant will not be able to prove that the lawmakers' purported purpose was not their actual purpose. Thus, in most cases the critical issue will be whether the lawmakers' purported judgment of wrongdoing was plausible. On what basis might a court evaluate such a judgment? Some judgments of blaine are so widely accepted in our society that they would be very unlikely to be questioned. For example, it is generally considered wrong intentionally to cause physical injury to others. ${ }^{211}$ More broadly, engaging in conduct knowing that it poses a serious threat to the health or safety of others is generally regarded as wrong. We also consider it wrong to lie, cheat, and steal. The Court would be unlikely to be faced with a takings challenge to a law embodying this type of judgment of wrongdoing, because the judgment of blame not only is plausible but is widely accepted.

In other cases, it is generally accepted that $A$ is not acting wrongfully. For example, excluding others from one's land is generally not

209. Keystone, 480 U.S. at 487 n.16.

While some may find this reading of Pennsylvania Coal unpersuasive, the Court's opinion in Keystone, combined with the Nollan decision, demonstrates the present Court's willingness to take into account the lawmakers" "actual purpose" in the unusual case where the actual purpose can be shown to be at odds with the purported purpose of the challenged legislation. The Court did not discuss the difficult process of ascertaining the purpose of a collective decisionmaking body in either Keystone or Nollan. However, it has addressed that issue in other contexts. See, e.g., Hunter v. Underwood, 471 U.S. 222, 227-33 (1985); Village of Arlington Heights v. Metropolitan Hous. Corp., 429 U.S. 252, 266-68 (1977). The subject of legislative purpose has, of course, provoked considerable academic commentary. See, e.g., Brest, Reflections on Motive Review, 15 SAN DiEgo L. REv. 1141 (1978); Brest, Palmer v. Thompson: An Approach to the Problem of Unconstitutional Legislative Motive, 1971 SuP. CT. REV. 95; Ely, The Centrality and Limits of Motivation Analysis, 15 SAN DrEgo L. REv. 1155 (1978); Ely, Legislative and Administrative Motivation in Constitutional Law, 79 YALE L.J. 1205 (1970).

210. See, e.g., Kissinger v. City of Los Angeles, 161 Cal. App. 2d 454, 462, 327 P.2d 10, 16 (1958) ("A zoning ordinance may not be used as a device to take property for public use without the payment of compensation. That the purpose of the ordinance was to depress the value of the plaintiffs' property in order that it might be acquired for airport purposes at such depressed value is crystal clear from the evidence.") (citations omitted); City of Baltimore v. Kelso Corp., 281 Md. 514, 520,380 A.2d 216, 220 (1977) (under the takings clause of the state constitution, a local government "cannot use zoning to depress land values so as to reduce the damages paid by the sovereign when it otherwise validly imvokes its power to condemn"); Grand Trunk Ry. v. City of Detroit, 326 Mich. $387,400,40$ N.W.2d 195, 200 (1949) (zoning ordinance designed to depress the value of land that the city might wish to acquire in eminent domain proceeding held to be "unreasonable and confiscatory"). In such cases, a taking is found because the actual purpose of the law was to avoid the just compensation requirement, whatever the proffered justification unay have been. It is difficult, of course, to prove that this was the lawmakers' actual purpose.

211. In some cases, however, such conduct is considered justified, as in the case of self-defense. 
considered wrongful. ${ }^{212}$ Accordingly, the claimant in a takings case is particularly likely to prevail if the government has prohibited her froin excluding others froin her land. Nor is it generally considered wrongful not to share specific tangible possessions, such as one's home or car, with others. ${ }^{213}$ We might say im such a case that we do not blame $A$ for failing to confer a benefit on others. ${ }^{214}$

How might a court articulate some of the factors that enter into commonly held judgments of wrongdoing? ${ }^{215}$ The limitless variety of contexts in which such judgments are made makes it impossible to give a comprehensive answer to this question. Nevertheless, it is instructive to address this question in a number of specific contexts involving land use, because so many takings claims involve land-use regulation.

Consider a zoning ordinance that prohibits any new coinmercial uses in an established single-family residential area. The ordinance deprives $A$ of the economically valuable freedom to use her land for commercial purposes, yet it would not be regarded as effecting a taking. ${ }^{216}$ Why might the introduction of a commercial use into an established single-family residential area be considered blameworthy?

At least three factors appear to affect societal judgments as to who is the wrongdoer when the desires of two groups of landowners conflict with respect to a land-use inatter. First, if an existing land use and a

212. There are exceptions, of course. For example, most people would consider it wrong of a landowner to exclude a government official who was enforcing laws designed to protect the public health and safety.

213. These statements assume that the "others" are strangers to $A$. However, if the "other" was $A$ 's child, we would consider it wrong of $A$ not to care for the child. Or if the "other" was someone who had detrimentally rehed on $A$ 's promise to share a particular resource, then we would (in most cases) consider it wrong of $A$ not to share that resource.

214. In other words, if the public would view $A$ as "doiug good" by sharing her resources with others, but would not consider it wrong of $A$ not to share, then a compensable taking would occur if the government forced $A$ to share. In some circumstances, however, the public would consider it wrong of $A$ not to contribute certain resources toward advancement of the public welfare. For example, it is generally considered wrong of $A$ not to pay her income taxes. In the case of income taxes, the lawmakers have broadly distributed the burdeu in a manner that they reasonably beheve the public would consider fair. See infra text accompanying notes 345-85.

215. Although the Court has sometimes stated that no taking occurs wheu the government simply prohibits $A$ from imjuring others, see, e.g., Hadacheck v. Sebastian, 239 U.S. 394 (1915); Mugler v. Kansas, 123 U.S. 623 (1887), the Court has never provided a detailed explanation of why people would regard $A$ as having acted wrongfully. Ackerman remarked in Private Property and the Constitution: "Since Ordinary Observing presupposes a common understanding of certain basic concepts that organize social reality ... it should not be surprising that Ordinary judges rarely engage, at least in casy cases, in self-conscious examination of those concepts." B. ACKERMAN, supra note 66 , at 236 n.3.

216. In its landmark opinion sustaining the constitutionality of zoning ordinances that segregate land uses, the Court held im Village of Euchid v. Ambler Realty Co., 272 U.S. 365 (1926), that industrial uses could be excluded from areas zoned for residential nses of various types, and that commercial uses and multi-family dwellings could be excluded from areas zoned for single-family and two-family residential uses. Village of Euclid is discussed more fully at infra text accompanying notes $265-68$ and 507-09. 
proposed new use will conflict, we tend to see the new use as the wrongful one, rather than blaming the existing use or saying that neither side is to blame. Second, when two land uses conflict, we tend to view the land use that would generate a lower level of adverse impact on others as having a superior claim. Single-family residential uses are generally viewed as having a less significant adverse impact on neighboring uses than commercial uses. Third, a widespread pattern of land use in a particular area inay establish the norm of acceptable conduct in that area. For exainple, if an area is predominantly single-family residential, that use is likely to be regarded as the norm, while uses that produce a more serious adverse impact on neighbors are regarded as wrongfully harming others in the neighborhood. ${ }^{217}$ In this example, all three factors support the conclusion that it would be considered wrong of $A$ to introduce a commercial use into this single-family residential area. The single-family residences were there first; commercial uses are viewed as having a more serious adverse impact on their neighbors than single-family residential uses; and single-family residential use is the predominant pattern in the area.

The more difficult cases tend to be those in which these three factors do not all lead to the same conclusion. Hadacheck v. Sebastian ${ }^{218}$ was such a case. The Court in Hadacheck held that no taking occurred when the City of Los Angeles prohibited the operation of a brickyard in a certain area of the city, even though the claimant had established his brickyard when his land was not within the city limits and there were no dwellings nearby. The Court found that no taking occurred because the area "had become primarily a residential section and ... the occupants of the neighboring dwellings [were] seriously incommoded by the operations of [the claimant]."219 The law was "supported by [a] tenable belief that the continuance of the business was so detrimental to the interests of others as to require suppression." "220 In Hadacheck, one could say that the lawmakers reasonably beheved they were prohibiting blameworthy conduct. The second and third factors identified above supported a judgment that the claimant was in the wrong. Brickyards generated a higher

217. Similarly, Robert Ellickson observed in Alternatives to Zoning: Covenants, Nuisance Rules, and Fines as Land Use Controls:

In ordinary speech . . . people consistently distinguish "harms" froin "benefits" . . . . Evaluative terms like good, bad, beneficial, and harmful are easily used because people have remarkably consistent perceptions of normal conditions and thus can agree in characterizing deviations from normalcy. ... A specific land use is characterized in ordinary speech as beneficial when it would have a more positive than usual inpact, and harmful when it would have a more negative than usual impact, on the values of normal surrounding properties ....

Ellickson, supra note 171, at 729.

218. 239 U.S. 394 (1915).

219. Id. at 409 .

220. Id. (quoting Ex parte Hadacheck, 165 Cal. 416, 421, 132 P. 584, 587 (1913)). 
level of adverse impact on neighboring uses than did the uses that were permitted in that district, and the pattern of land use in the area had coine to be residential. What made this a difficult case was that the brickyard was there first. Yet judgments of blame in our society are not based solely on who was there first. Even if the brickyard was not considered a wrongful land use when it was imitiated, it could be considered wrongful to operate a brickyard later if it disturbed those living nearby. ${ }^{221}$

Let us now inove to the general question of how a court might assess the reasonableness of a judgment of wrongdoing, without focusing specifically on cases imvolving conflicting land uses. One very important question to ask in assessing the reasonableness of a judgment of wrongdoing is: Who is being asked to bear the burden imposed by this law? If the lawmakers assert that it would be wrong of anyone who does $X$ not to give up $\mathrm{Y}$, the reviewing court might evaluate that judgment by asking: "Why should this group alone bear the burden imposed by the law? Why would it be wrong of those who do $X$ not to give up $Y$, if it is not considered wrong of others not to give up Y?"

The exaction challenged in Nollan v. California Coastal Commission, ${ }^{222}$ for exainple, was especially difficult for the government to defend because the requireinent of providing lateral public beach access was imposed only on those beachfront landowners who wanted to build on their land. The government had to explain why it was wrong of a beachfront owner who wanted to build on his land not to provide public access, if it was not wrong of other beachfront landowners not to do so.

221. The "who was there first" factor troubled Sax. Citing Hadacheck, he stated:

The typical nuisance situation is one in which a perfectly lawful industrial enterprise located on the outskirts of the city suddenly finds itself in the midst of a new and unforeseen residential development. It can hardly be said that the industrial user created this evil which is now sought to be reinedied; the patent fact is that the evil was created by the unfortunate juxtaposition of two lawful activities.

Sax I, supra note 147, at 49 (citation omitted).

Michelman was also troubled by the Hadacheck decision because the brickyard was there first. Unlike Sax, he did not contend that no moral judgment could be made in a case like Hadacheck. Rather, he argued that "first in time" is necessarily "first in right." Michelman asserted that it is impossible to tell "which of two incoinpatible activities is 'the' nuisance, except by asking which actor acted only after the situation had developed to the point where he should have rcalized that the other had already coininenced to rely on his conflicting vision of the future." Michelman, supra note 164, at 1243-44 (emphasis in original). According to Michelman, it is "well recognized" in private nuisance law that the plaintiff cannot prevail if he "came to the nuisance." Id. at 1244 n.132. The Restatement, however, states that this is merely one factor to consider. RESTATEMENT (SECOND) OF TORTS $\S 840 D$ (1977); accord W. PROSSER, HANDBOOK OF THE LAW OF TORTS $\S 91$, at 611 (4th ed. 1971).

Epstein, however, argued in Takings that in "coming to the nuisance" " takings cases, "[t]ime is irrelevant." R. EPSTEIN, supra note 28, at 118-19. As Epstein saw it, if "the brickmaker has seut fumes from his factory onto the lands of the other party," then he is clearly the cause of the harm and cannot escape liability by arguing that he was there first. Id.

222. 483 U.S. 825 (1987). 
Although the government argued that it was simply asking those who built on beachfront land to mitigate the harm to the public caused by building, the Court was not persuaded. Given the difficulty of establishing that public access would imitigate the harm caused by building, the access requirement would have been easier to defend had it applied to all beachfront landowners. The State of Califorma could then have argued that the lawmakers reasonably believed that the people of California would consider it wrong of any owner of beachfront land to prevent the public froin traversing the shoreline. ${ }^{223}$

Loretto v. Teleprompter Manhattan CATV Corp. ${ }^{224}$ illustrates the same primciple. The law challenged in Loretto applied only to landlords. It required them to permit the installation of cable facilities to serve their own tenants ("noncrossover installations"), and it also required them to permit the installation of cable facilities to enable those hiving in other buildings to receive cable television ("crossover installations"). The reasonableness of any judgment of moral responsibility inade in Loretto must be assessed in light of the fact that only landlords bore the burden of this law.

Looking first at "noncrossover installations," $A$ 's conduct (renting his building) does bear soine relationship to what $A$ is being asked to do (permit the installation of cable facilities to serve $A$ 's tenants). Perhaps the lawmakers could reasonably have concluded that, because of a landlord's relationship with his tenants, the public would consider it wrong of a landlord to refuse to permit the installation of facilities that would enable his own tenants to receive cable television service. According to the dissenters in Loretto, the state legislature concluded that "[a] landlord should not be able to preclude a tenant from obtaining CATV ser-

223. Similarly, in Takings, Private Property and Public Rights, Sax argued that there is an "equal protection element" to takings law, which "prevent[s] discriminatory restriction of any one of a number of identically situated owners." Sax II, supra note 169, at 166 n.32. He illustrated this principle with the following example:

[I] $n$ the ordinary case, a landowner abutting the shore of the ocean could not be required to provide access across his land, without receiving compensation, because there is no reason to choose his land for an easement rather than the land of any one of a number of similarly situated abutting landowners. However, access could, without compensation, be required of one owner who holds all the abutting land, or of all the shoreland owners.

Id. (emphasis added). Unlike this Article, however, Sax did not argue that the distribution of the burden imposed by a law should be considered in assessing the reasonableness of the moral justifieation for the law proffered by the government. Despite his reference to an "equal protection" element to takings law, Sax argued that the takings cases could not be viewed as resting on a moral basis.

Epstein, on the other hand, argued in Takings that no taking occurs when the government is preventing wrongdoing, but he defined wrongdoing very narrowly. If the government is not seeking to combat force or fraud, it is not seeking to prevent wrongdoing. See supra note 181. That the law applied broadly did not change this conclusion. "[W] here the state issues a general directive against many persons similarly situated, it has engaged in a mass partial taking of private property .... The wrongs of the government ... are strictly additive." R. EPSTEIN, supra note 28, at 101.

224. 458 U.S. 419 (1982). 
vice (or to exact a surcharge for allowing the service) any more than he could preclude a tenant from receivmg mail or telegrams directed to him."225

Turning to the requirement that "crossover installations" be permitted, however, it is far more difficult to argue that there is a relationship between $A$ 's conduct (renting his building) and what $A$ is being asked to do (permit the installation of facilities that will enable people living in other buildings to receive cable television). How does $A$ 's conduct in renting his building justify the imposition of this burden? That is, why is it wrong of landlords not to permit the mstallation of cable facilities that serve strangers, if it is not wrong of other building owners not to permit the installation of such facilities? ${ }^{226}$

Perhaps the lawmakers did not make a judgment of moral responsibility with respect to the crossover installations. The lawinakers may have concluded that it was wrong of landlords not to permit their own tenants to receive cable television, and then decided to require landlords to permit crossover mstallations as well, simply because this would benefit the public. The New York Court of Appeals explained that the lawinakers' purpose in requiring landlords to permit crossover installations was to "promote the rapid development of the [cable television] industry," which would benefit the public. ${ }^{227}$ Moreover, even if one assumes that the lawmakers made a judgment of moral responsibility with respect to the crossover installations, the reasonableness of that judgment could be questioned because of the lack of connection between the burden imposed and the conduct of those required to bear that burden. As in Nollan, the exaction would have been easier to defend had it apphied more broadly. ${ }^{228}$

225. Id. at 445 n.3.

226. More specifically, the law required landlords to permit the installation of crossover facilities without receiving compensation. Loretto v. Teleprompter Manhattan CATV Corp., 53 N.Y.2d 124, 141-42, 423 N.E.2d 320, 328, 440 N.Y.S.2d 843, 850-51 (1981). By contrast, a building owner who did not rent out his building would receive compensation if a cable television company used formal eminent domain proceedings to obtain the legal right to run cable TV lines across the building. Id. at $137-38,423$ N.E.2d at 326,440 N.Y.S.2d at $848-49$.

227. Id. at 142,423 N.E. $2 \mathrm{~d}$ at 328,440 N.Y.S.2d at 851 .

228. See supra text accompanying notes 222-23.

Neither the majority nor the dissent in Loretto distinguished between crossover installations and noncrossover installations. The majority concluded that both were takings because they constituted permanent physical occupations. 458 U.S. at 438 . The dissent argued that "the fact that [the statute] incidentally protects so-called 'crossover wires' . . . does not affeet [its] fundamental character as a piece of landlord-tenant legislation." Id. at 448 n.6 (Blackmun, J., dissenting). The dissent added that "assuming, arguendo, that the crossover extension in this case works a taking, I would be prepared to hold that [it] is a de minimis deprivation entitled to no compensation." Id. at 449 n.6. 


\section{E. Preventing Harm Versus Preventing or Punishing Wrongdoing}

The principle that no taking occurs if the government is preventing or punishing wrongdoing by $A$ inay sound similar to a "harm-benefit" test for determining whether a taking occurs. Under a "harm-benefit" test, no taking occurs if the governinent is preventing $A$ from causing harm to others, but a taking does occur if the government is requiring $A$ to benefit others. ${ }^{229}$ It inay be useful at this point to further explicate the inoral justification principle by comparing it to the harm-benefit test. As shown below, the two approaches differ, and to the extent that they differ, the noral justification approach offers a niore lielpful and complete insight into the Court's takings decisions.

One can inore accurately describe when the Court will find a taking by asking whether the government was seeking to prevent or punish wrongdoing by $A$, rather than by asking whether the government was stopping $A$ froin causing harm to others. To begin with, the harm-benefit test does not address those cases in which the government is requiring $A$ to give up her property to punish her for wrongdoing. The harm-benefit test simply asks whether the government is stopping $A$ from causing harm to others. But suppose the government required $A$ to pay a fine for committing a crime or to pay punitive damages for maliciously committing a tort. In each case, no taking would occur because the governinent would be purrishing $A$ for having acted wrongfully, not because the government would be stopping $A$ from acting in a harnnful nranner.

Even if one sets aside those cases in which the governinent is punishing wrongdoing, the harm-benefit test differs from the approach I offer in

229. Such a "harm-benefit" test is often attributed to Ernst Freund, who stated in The Police Power:

Under the police power, rights of property are impaired not because they become useful or necessary to the public, or because some public advantage can be gained by disregarding them, but because their free exercise is believed to be detrimental to public interests; it may be said that the state takes property by eminent domain because it is useful to the public, and under the police power because it is harmful . . . .

E. Freund, The Police Power 546-47 (1904). Freund's apparent thesis in this passage was that no taking occurs when the government prohibits $A$ from using ler property in a manner that las an adverse impact on others.

The "harm-benefit" test is also attributed to Allison Dunham. Dunham suggested such a test in A Legal and Economic Basis for City Planning, stating:

From time immemorial the common law and statute law have evidenced a community judgment that it is proper to make an activity assume the burdens or costs which that activity might cause. ...

... But to compel a particular owner to undertake an activity to benefit the public, even in the form of a restriction, is to compel one person to assume the cost of a benefit conferred on others without hope for recoupment of the cost. ...

...

... There is much in American constitutional law to support this distinction, althougl precise accuracy in application is not required under the rule of deference to the legislative judgment.

Dunham, A Legal and Economic Basis for City Planning, 58 Colum. L. REV. 650, 665-66 (1958). 
this Article. To say that no taking occurs if the government is preventing $A$ from causing harm is not the same as saying that no taking occurs if the government is preventing wrongdoing by $A .{ }^{230}$ The two approaches are not identical because conduct that causes harm to others is not always considered wrongful, and wrongdoing does not always involve causing harm to others. ${ }^{231}$

First, conduct that harms others is not necessarily considered wrongful. For exainple, suppose $A$ built a house on her lot, and this lowered the value of surrounding homes. Although $A$ 's conduct would have harmed others, this alone would not establish that she had acted wrongfully. ${ }^{232}$ Under the moral justification principle, if the government prohibited $A$ from building on her land and the lawmakers had no reasonable basis for concluding that the public would consider it wrong of $A$ to build, a taking would occur even though $A$ 's proposed conduct would have had an adverse impact on others. ${ }^{233}$

Second, conduct may be considered wrongful even if it does not cause harm to others. ${ }^{234}$ For example, a state or local legislative body

230. It is true that the two tests overlap considerably, because we often consider it wrong of $A$ to cause harm to others. Any law prohibiting conduct that is viewed as wrongfully causing harm to others would not effect a taking under the harm-benefit test or under the moral justification principle. For example, a law prohibiting $A$ from manufacturing a product that causes serious physical injury to users and third parties would not effect a taking.

231. Of course, the term "harm" can be used in a variety of ways. In Harm to Others, for example, Joel Feinberg first distinguished "hurting" or "offending" from "harming" and then offered a number of different definitions of the word "harm." J. FeINBERG, HARM To OTHERs 31$36,45-51$ (1984).

One of the difficulties one encounters in responding to the "harm-benefit" test is that Freund and Dunham did not explaim in any detail what they mcant by the term "harm." It seeins, however, that they were using the phrase "to harm others" to mean "to have an adverse impact on others," for both Freund and Dunham used a "harm-benefit" test to distinguish those cases in which the claimant's conduct had an adverse impact on others froin those cases in which the government was forcing the clainant to have a positive impact on others.

232. This is true even if the sum total of the adverse impact caused by $A$ 's conduct is greater than the sum total of the positive impact caused by $A$ 's conduct. For in some cases, conduct that is undesirable froin a cost-benefit standpoint is not considered wrongful.

Suppose, for example, that $A$ owns a vacant lot in a single-farmily residential area. Neighboring children enjoy using $A$ 's vacant lot as a play area, and others appreciate having soine open space in a densely populated neighborhood. If $\boldsymbol{A}$ were to build a single-family residence on her land, the adverse impact caused by $A$ 's conduct inight exceed the suin total of the positive inpact caused by $A$ 's conduct. Yet this would not establish that $A$ was acting "wrongfully" in building a dwelling on her own land. One question to ask in assessing a purported judgment of wrongdoing here would be: Why would it be wrong of $A$ to build a home on her land, if it was not wrong of $A$ 's neighbors to build hoines on their land? See the discussion of "singling out" at supra text accompanying notes 222-28.

233. For example, in the hypothetical discussed at supra note 232, a reviewing court would be likely to conclude that there was no plausible basis for a judgment of wrongdoing. Similarly, in Nollan v. Califonria Coastal Commission, 483 U.S. 825 (1987), the government had no reasonable basis for concluding that it would be wrong of the Nollans to build without providing lateral public beach access. See supra text accompanying notes 202-06 \& 222-23.

234. This statement assumes that "causing harm" refers to something other than offending 
might prohibit the sale of liquor (or prohibit the sale of hiquor on Sundays) because the people in that jurisdiction consider sucli conduct to be immoral, wholly apart froin any judgment that such conduct causes harm in any tangible sense. Laws embodying sucl moral judgments are generally assumed not to effect takings. The principle seems to be that no taking occurs because the government is preventing conduct that is considered wrongful, ratler than that no taking occurs because the government is preventing the claimants from causing harm.

Moreover, conduct inay be considered wrongful simply because it could cause harm to others, even if it does not cause actual physical injury or damage to tangible resources. ${ }^{235}$ For exainple, behavior that presents a significant risk of causing serious physical injury to others is generally considered wrongful. The probability of the conduct causing adverse consequences to others and the seriousness of those potential consequences are among the factors that determine whether particular conduct that might liave an adverse impact on otlers is judged to be blameworthy. ${ }^{236}$

people's sense of right and wrong. However, Freund may have intended to include offense to moral judgments within the concept of "harm," for at one point in his treatise he stated that a thing could be destroyed if it was "offensive to the morals of the community." E. FREUND, supra note 229, at 554.

235. It is possible that Freund or Dunham would have characterized conduct that creates some risk to others as conduct that "causes harm." As noted above, see supra note 231, neither author provided a clear explanation of what he meant by the term "harm." Yet Freund at least seemed to be using the term "harm" to mean physical injury (or damage to material resources) that had already occurred or was about to occur. Freund stated that when the government is engaging in "mere regulation," it "need not restrict itself to conditions actually harmful, but may require precautions within the whole range of possible danger," while a "taking or destruction" of property can be justified "only within the narrowest limits of actual necessity:" E. FrEUND, supra note 229, at 555 .

Note that in the quoted passage, Freund not only distinguished between "harm" and "benefit," but also distinguished between "mere regulation" and "taking or destruction." Although Freund is often cited as having proposed a "harm-benefit" test in The Police Power, he frequently departed from a harm-benefit test in explaining when a taking occurs. For example, at one point in his treatise Freund relied on a "no economically viable use" test, stating: "That the law restricts the exercise of rights of property to uses and modes of disposition less profitable than those previously allowed, does not amount to a taking of property, if other profitable methods of disposition remain lawful." Id. at 550 .

236. This is not to suggest that application of the Learned Hand formula, see United States $v$. Carroll Towing Co., 159 F.2d 169 (2d Cir. 1947), is necessary or sufficient to determine that $A$ is guilty of wrongdoing. We generally do not determine that $A$ is at fault simply because the burden on $A$ of avoiding an adverse impact to $B$ is less than the probability of the adverse impact occurring, multiplied by the severity of the potential adverse impact.

Even in the law of negligence, the Learned Hand formula alone does not determine whether $A$ 's conduct is considered wrongful. The first step in attributing blame is viewing $A$ as responsible for the harm suffered by $B$. If we view $C$ as the cause of the harm and do not believe $A$ was morally responsible for preventing $C$ from harming $B$, then we say that $A$ had no "duty to act." Thus, we conclude that $A$ 's conduct was not wrongful without considering the Learned Hand formula. Even if we view $A$ as the cause of the harm suffered by $B$, we may not regard $A$ 's conduct as "wrongful" if the harm suffered by $B$ was of a certain type. For example, if $B$ was inconvenienced by $A$ 's conduct 
Finally, a failure to act is soinetimes considered wrongful, even if one ordinarily would not say that the particular failure to act had "caused harm."237 For example, suppose a state law required all school teachers to report known instances of child abuse to the proper governmental agencies. ${ }^{238}$ The public might well consider it wrong of a teacher not to take such action, given her relationship to the child and the risks posed to the child, even if the public would not say that the government was stopping the teacher from "causing harm" to the child. ${ }^{239}$ The pubhic would probably conclude that the teacher had a moral obhigation to take steps to reduce the risk that others might harm the child in the future. ${ }^{240}$

Thus, the harm-benefit test, taken at face value, differs from the moral justification primciple. Yet it may well have sprung from the same intuitions. The harm-benefit test may have been based on the implicit preimse that "harming" others is bad, and thus can be stopped without coinpensation, while requiring $A$ to "benefit" others amounts to requiring $A$ to do good, and thus requires the payinent of coinpensation. ${ }^{241}$

but did not suffer physical injury or acute emotional injury, we might regard $A$ 's conduct as undesirable (using the cost-benefit analysis of the Learned Hand formula), yet not regard it as tortious or otherwise wrongful.

To provide another example froin the area of property law, we generally consider trespass wrong, even though the burden on $A$ of letting $B$ enter her land may be less than the probability of $B$ suffering an adverse impact from being excluded, multiplied by the severity of that potential adverse impact. In Nollan v. Califorma Coastal Commission, 483 U.S. 825 (1987), for example, it may have been undesirable for the Nollans to exclude the public from their beachfront land (applying the Learned Hand formula), yet the Court evidently did not regard it as wrongful of thein to do so. See supra text accompanying notes 202-06.

237. Both Freund's and Dunham's "harm-benefit" tests focus on cases in which $A$ acted in a manner that harmed others (thus "causing harm"), rather than considering cases in which $A$ failed to act.

238. See, e.g., CAL. Penal Code $\S 11166$ (a) (West 1982 \& Supp. 1989).

239. Nor is the teacher being asked to reinedy harm that she had previously caused.

240. Alternatively, consider a law that requires $A$ and others to serve in the military. The public might well consider it wrong of $A$ and others not to serve in the military (or, in the case of a conscientious objector, to perform alternative service). See infra text accompanying notes 345-68. But inost people would not say that the government is stopping $A$ from "harming" others when the government requires $A$ to serve in the military.

241. Although his test simply asked whether the claimant was "causing harm," Dunham at times seemed to be concerned about issues of blame. For example, Dunham stated that it was impossible to reconcile United States v. Caltex, Inc., 344 U.S. 149 (1952), with a "harm-benefit" test because the clainants in Caltex were not at fault for the situation in which they found theinselves. Thus, in Dunham's view, they did not "create" the "public harm." Dunlam, supra note 56, at 7780. Therefore, he concluded that Caltex could only be viewed as a case in which the government had unfairly extracted a benefit from the claimants witlout payment of coinpensation. Id.

Unlike Dunham, Freund evidently did not assume that the clainant had to be at fault for being in the situation facing her, for Freund viewed an industrial use in a residential zone as "causing harm" even when the industrial use was there first. E. Freund, supra note 229, at 561. See the discussion of "coining to the nuisance" takings cases at supra note 221 and accoinpanying text.

The moral justification principle asks whether the clainant can be blained for behaving in a particular inanner given the situation facing him. We inay blame the claimant for failing to act iu a 


\section{F. Variation in Moral Judgments Temporally and Geographically}

Under the moral justification principle, whether a taking occurred depends upon whether the government deprived $A$ of her property to prevent or punish wrongdoing by $A$. But what of the fact that judgments of wrongdoing may change over time and may vary geographically? The moral justification principle takes this factor into account by focusing on whether the lawmakers reasonably believed the conduct at issue would be regarded as blameworthy by the people of that jurisdiction at that time. ${ }^{242}$

Clearly, standards of what constitutes blanieworthy behavior change over time. Conduct that the public once considered wrongful niay later be viewed as acceptable, even desirable. For example, during Prohibition, lawmakers reasonably believed that the public considered it wrong to manufacture or sell alcoholic beverages. Today, lawinakers in most jurisdictions reasonably believe that the public does not consider it wrong to nianufacture or sell alcohohic beverages if certain conditions are met.

Conversely, conduct that was once considered acceptable by the public niay later be viewed as blameworthy. For exaniple, one can imagine that over time public attitudes toward the manufacture of cigarettes might change so that such conduct would come to be regarded as blanieworthy. ${ }^{243}$ Certainly attitudes toward land developmient liave changed over time. ${ }^{244}$ Fifty years ago, for example, a law that prohibited the owner of an historically significant building from destroying the exterior

particular manner given the situation, even if we do not fault him for finding himself in that situation. For example, we might blame a school teacher for failing to report a known case of child abuse, even though the teacher could not be faulted for the abuse itself or for knowing of the abuse. See supra text accompanying notes 237-40. Similarly, we might blame the claimants in Caltex if they refused to let the government destroy their oil facilities, even though we could not blame them for the fact that the enemy was at hand. See supra notes 182-85 and accompanying text.

242. In fact, the issue in most cases is whether the lawmakers reasonably could have believed that the public would regard the conduct as wrongful. Under the moral justification principle, a judgment of wrongdoing will be presumed if such a judgment reasonably could have been made, unless the evidence shows that in fact no such judgment was made. See supra text accompanying notes 177 \& 207-10.

243. Ackerman remarked in Private Property and the Constitution that although manufacturing cigarettes is not considered "a plainly improper activity for a well-socialized person," it is "in the gray area of socially questionable conduct." B. ACKERMAN, supra 11ote 66, at 152. Ackerman argued that if such conduct were prohibited, "an Observing judge would have little difficulty understanding it as an attempt by legislators to express the developing concept of socially harmful conduct rather than as an assault on Layman's things without Ordinary justificatiou." Id. at 152-53 (emphasis added). Similarly, under the moral justification principle, no taking would occur if a law were enacted prohibiting the manufacture of cigarettes so long as the lawmakers reasonably believed they were prohibiting conduct that the public considered wrongful.

244. Ackerman observed in Private Property and the Constitution that one encounters the notion that "a well-socialized [person] ought to . . . refrain from causing undue damage to things like Nature or Tradition .... in the political and legal discourse generated by the movements for environmental and historical conservation." Id. at 155. 
of the building would probably have been perceived by the public as prohibiting the owner from acting in an undesirable manner, perhaps, but not a wrongful manner. ${ }^{245}$ Today, however, it may well be that lawmakers in many localities could reasonably believe that their constituents would consider it wrong to destroy the exterior of an historically significant building. The Supreine Court suggested as inuch in Penn Central Transportation Co. v. New York City, ${ }^{246}$ when it stated:

[It cannot] be asserted that the destruction or fundamental alteration of a historic landmark is not harmful. The suggestion that the beneficial quality of appellants' proposed construction is established by the fact that the construction would have been consistent with applicable zoning laws ignores the development in sensibilities and ideals reflected in landmark legislation like New York City's. ${ }^{247}$

Because judgments of wrongdoing vary over time, what constitutes a taking also varies over time. The same law might effect a taking in one era and not in another. Yet the general principle remains the same: No taking occurs if the lawinakers sincerely and reasonably beheve they are preventing or punishing conduct that the people of that jurisdiction would consider wrongful. ${ }^{248}$

245. Indeed, the public may lave viewed the destruction of an older building to make way for a larger, more modern structure as desirable, even if the older building was historically significant. This might be true today as well, but in an earlier era there was a greater value placed on growth and developinent. Sax noted this gradual change in pnblic values in. Some Thoughts on the Decline of Private Property, 58 WASH. L. REV. 481 (1983):

[V]alues are changing, so that the quantum of benefits from developmental activity . . . is perceived as being less than it formerly was. ...

....

... [A]s growth and development seem to become less valuable girides for future wellbeing, those things that speak to sustenance, continunity, adaptation and evolutionary change rise slarply in value. ... [For example,] historic preservation [speaks] to tlie continuity of the social order....

Id. at $489-90$.

246. 438 U.S. 104 (1978).

247. Id. at 134 n.30. Since the Court had previously discussed whether the noxious use cases involved "blameworthiness [or] moral wrongdoing," id., the Court apparently was stating in this passage that destroying or fundamentally altering an historic landmark conld be regarded as wrongful, not just harmful.

By way of contrast, Epstein would not even entertain the possibility that the fundamental alteration of an historic landmark might be considered wrongful. Rather than asking whether tlie public would consider tlie conduct to be wrongful, lie asserted that "wrongdoing" necessarily involves force or fraud. See supra note 181. Moreover, even within that limited group of cases, it is not at all clear tlat Epstem would view the concept of "wrongdomg" as changing over time as public values change. For example, Epstein asserted at one point in Takings that "modern accounts of assumption of risk in private law are themselves misguided and erroneous" and therefore should not be considered in determining whether the government is seeking to prevent wrongful conduct. $R$. EPSTEIN, supra note 28, at 152.

248. In Takings and the Police Power, Sax argued that takings cases could not and slould not be decided on the basis of judgments of what constitutes a "nuisance," in part because those judgments change over tine. For example, Sax noted that in 1843 a New York court lad judged a bowling alley to be a common-law nuisance, stating tliat it was 
Moral judgments not only change with time, but they also vary from one jurisdiction to the next. Certain conduct may be considered a tort or a crime or a nuisance in one state but not in another. Statutes providing for forfeiture of resources used in the commission of crimes differ from one state to another. Land-use regulations differ from one locality to another, at least in part because values regarding what constitutes blameworthy conduct vary from one locality to the next. ${ }^{249}$

Under our federalist system, state and local governments have considerable freedom to act in accordance with their own notions of what constitutes blameworthy conduct. ${ }^{250}$ States are free, for example, to have different definitions of what constitutes tortious conduct. ${ }^{251}$ The takings clause evidently does not require state and local governinents to choose between adhering to a national standard of what constitutes blameworthy conduct or paying just compensation whenever they depart from that national standard. We assume that no taking occurs, for example, when

"[a] useless establishment, wasting the time of the owner, tending to fasten his own idle habits on his family, and to draw the men and boys of the neighborhood into a bad moral atınospliere-a place which, despite every care, will be attended by profligates, with evil communication, and at best with a waste of time and money, followed by the multiplication of paupers and rogues...."

Sax I, supro note 147, at 49 n.75 (quoting Tanner v. Trustees of the Village, 5 Hill 121, 128 (N.Y. 1843)).

Sax was correct, of course, in noting that judgments of what constitutes a "nuisance," like other judgments of wrongdoing, cliange over time. But this sliould not be a source of concern. The principle that a taking occurs when the government intentionally and without moral justification deprives a private party of property remains constant, altlough the acts that constitute a taking change as public values change.

249. For example, one locality may consider it wrong to build in a manner that is likely to lead to a certain degree of congestion downtown, wliile another locality may come to a contrary conclusion. Or one locality may consider it wrong to destroy or substantially alter historically significant buildings, while another locality nay not.

Some of the variation in land-use regulations may be attributable to geographic differences in certain relevant objective facts. For example, operating a factory that emits a certain amount of smoke might be considered wrong in city $\mathrm{X}$ but not in city $\mathrm{Y}$, because city $\mathrm{X}$ has an air pollution problem and city $\mathrm{Y}$ does not.

250. In sone cases, laws other than the takings clause prohibit state and local governments from giving effect to state and local values regarding what constitutes wrongful action or failure to act. National laws other than the takings clause (including federal constitutional guarantees) often provide, im effect, that national values take precedence over state and local values, including state and local values regarding whit constitutes wrongdoing. Similarly, state laws often provide, in effect, that state values take precedence over local values, including local values as to what constitutes wrongful behavior.

251. As discussed above, Eisenberg argued in The Nature of the Common Law that courts should and do employ "social norality" in developing common law rules, including tort laws. M. EISENBERG, supra note 155, at 15 . Eisenberg acknowledged that where the moral norms of the particular jurisdiction differed from those of other jurisdictions, the locality's norms would govern in developing common law rules. He stated that "[i]n theory, the relevant conmunity for this purpose is the jurisdiction (normally, a state) whose law governs a transaction." Id. at 167 n.6. Yet he also stated that "[i]n practice, moral norms are usually not so local, and the court will typically look to a wider regional or national community unless it lias reason to believe that the norms of the governing jurisdiction are special." Id. 
a state requires $A$ to pay damages for acting in a manner that constitutes a tort in that state, even if such conduct is not considered tortious in most other states. Furthermore, the Court has rejected takings challenges to state laws designed to prevent conduct that was considered wrongful in that particular jurisdiction without inquiring whether such conduct would offend nationally held values.

In Mugler v. Kansas, ${ }^{252}$ for example, the Court rejected a takings challenge to a state law prohibiting the manufacture of alcoholic beverages-conduct that the people of Kansas considered wrongful at the time. This was not the national consensus at that time, at least if prevailing state and federal laws reflected contemporaneous public values. ${ }^{253}$ Yet the Court held that no taking occurred, stating that the challenged law represented the judgment "of the people [of Kansas] as expressed by their chosen representatives" that the manufacture of alcoholic beverages should be prohibited "to guard the community against the evils attending the excessive use of such hquors."254 Mugler has not been regarded as a difficult case, despite the severe economic loss imposed on the claimant. Nor would one expect it to be difficult under the moral justification principle, as the lawniakers were clearly implementimg a moral judgment, even though that judgment was not in line with national values at the time. ${ }^{255}$

Similarly, in PruneYard Shopping Center v. Robins, ${ }^{256}$ the Court rejected a takings challenge to a provision of the California Constitution without inquiring whether that provision reflected values that were shared by the nation as a whole. The California Constitution, as interpreted by the state supreme court, prohibited a shopping center owner from excluding members of the public who were exercising rights of free expression and petition protected by the state constitution. The Suprenie Court held that this state constitutional provision did not effect a taking. Although the Court did not rely on this rationale, PruneYard could be explained as a case in which no taking occurred because the challenged

252. 123 U.S. 623 (1887).

253. See H. LeE, How Dry We Were: Prohibition Revisited at x-xi (1963) (providing a chronology of the enactment of "dry laws").

254. Mugler, 123 U.S. at 662.

255. In Private Property and the Constitution, Ackerman did not discuss geographic variation in moral judgments. He simply spoke of "dominant social expectations," as if moral judgments were uniform throughout the nation. B. ACKERMAN, supra note 66, at 95-96. Yet Ackerman did not consider Mugler a close case, viewed from the perspective of his Ordinary Observer. Id. at 153.

Epstein argued in Takings, supra note 28, that no taking occurs when the government is preventing wrongdoing, but he did not discuss geographic variation in judgments of wrongdoing. Epstein seemed to be arguing that the Court should judge the government's action according to a uniform set of rules regarding what constitutes wrongdoing. According to Epstein, "wrongdoing" necessarily involves force or fraud. See supra note 181 .

256. 447 U.S. 74 (1980). 
provision of the state constitution expressed the judgment of the people of California that, laving admitted the public to the shopping center, it would be wrong of the shopping center owner to exclude members of the public who wisled to speak and petition in a reasonable manner on the premises. There is no reason to beheve that this judgment was shared nationally. Indeed, the Supreme Court lad held eight years earlier in Lloyd Corp. v. Tanner ${ }^{257}$ that the first amendment did not prohibit such conduct by a shopping center owner. ${ }^{258}$

One might argue that the takings clause must provide soine hmit on what state and local lawmakers may do in the name of preventing or punishing blameworthy conduct, even if they sincerely and reasonably beheve they are implementing the values of their constituents. At present, however, the Court's takings decisions do not establish such a limit. In the few cases where one might have asked, "How could anyone think that is wrong?" the Court in effect has responded by saying, "The lawmakers did not believe they were prohibiting blameworthy conduct," rather than by saying, "The lawmakers sincerely and reasonably believed their constituents considered such conduct to be blameworthy, but the law nonetheless effects a taking." In Nollan, ${ }^{259}$ for example, the Court strongly suggested that the government's judgment of moral responsibility was insincere. The Court came very close to saying: "You may say you were seeking to prevent wrongful conduct, but we don't believe that was your purpose."260 In Webb's Fabulous Pharmacies, Inc. v. Beckwith, ${ }^{261}$ where the government simply "deemed" tlie interest earned on certain money deposited with the court to be government income, the Court essentially said, "You don't even purport to be depriving the claimants of their property based upon a judgment of wrongdoing."262

Thus, it appears that the takings cases can best be explained by

257. 407 U.S. 551 (1972).

258. The Court stated in PruneYard that Lloyd was not dispositive of the takings issue, since "Lloyd [did not] limit the authority of the State to exercise its police power ...." 447 U.S. at 81.

In Lloyd, the Court concluded that the first amendment did not prohibit the shopping center owner's conduct because that conduct was not "state action." 407 U.S. at 567-70. Perhaps the nation still considered the shopping center owner's conduct to be blameworthy. This would be difficult to establish, however, if no national law prohibited such conduct and if the laws of most states protected the shopping center owner's right to physically exclude those seeking to speak and petition on the premises.

259. 483 U.S. 825 (1987).

260. The Coastal Commission argued, in effect, that the government considered it wrong of the Nollans to build a single-family home on their lot without providing lateral public beach access. The Court rejected this argument as wholly implausible, referring to the "made-up purpose of the regulation," id. at 839 n.6, and stating that it was guarding against "extortion" and the "risk that the [government's] purpose is avoidance of the compensation requirement, rather than the stated police power objeetive." Id. at 837,841 .

261. 449 U.S. 155 (1980).

262. The Court emphasized that the government had offered no "police power justification" for deeming the imterest earned on the claimant's account to be the property of the state. It had just 
focusing on whether the lawmakers were seeking to prevent or punish conduct that they reasonably believed the people of that jurisdiction at that time would consider wrongful. Although there may be some limit to low far states or localities may diverge from generally lield views on right and wrong without effecting a taking, that limit is not apparent in the Court's takings decisions.

\section{G. Generalized Moral Judgments}

If the takings cases can be explained by saying that the issue is whether the government had a inoral justification for taking $A$ 's property, the question arises whether an individualized moral judgment is required whenever the government deprives $A$ of her property. The Court sometimes says that although $A$ has not shown that the challenged law effects a taking "on its face," she may be able to show that the law effects a taking "as applied" by producing evidence of how the law operates in her particular case. ${ }^{263}$ This suggests that some sort of individualized assessment of $A$ 's case is available. Yet if the takings clause were to require the payment of just compensation whenever an individualized assessinent of the claimant's conduct would not yield a judgment of wrongdoing, then whenever lawinakers enacted laws based on generalizations of wrongdoing, the government would be committing a taking in each case that proved to be an exception to the generalization.

For exainple, suppose a city council enacted an ordinance prohibiting the imtroduction of any commercial use into an established singlefamily residential area, based on a judgment that commercial uses usually produce unduly harmful consequences to neighboring residents, such as noise, increased traffic, and parking problems. Assuming that the lawmakers reasonably concluded that it generally would be considered wrong to introduce a commercial use into this area, could $A$ establish a taking merely by showing that her particular proposed commercial use would not produce these problems?

Since the Court in recent years has not analyzed takings cases by asking whether the government had a moral justification for depriving $A$ of her property, ${ }^{264}$ the Court has not explicitly focused on whether the government must inake an individualized assessment of wrongdoing. Back in 1926, however, the Court addressed that issue in Village of

"appropriat[ed] the beneficial use" of the fund deposited with the court. Id. at 163-64. See the discussion of Webb's at supra text accompanying notes 89-91.

263. See, eg., Hodel v. Indiana, 452 U.S. 314, 333-36 (1981); Hodel v. Virginia Surface Mining \& Reclamation Ass'n, 452 U.S. 264, 293-97 (1981); Agins v. City of Tiburon, 447 U.S. 255, 260-63 (1980).

264. As discussed in Part $I$, in recent years the Court has analyzed takings cases by applying the three-factor Penn Central test, the two-part Agins test, the "no cconomically viable use" test, or the Loretto per se rule. See Peterson I, supra note 4. 
Euclid v. Ambler Realty Co. ${ }^{265}$ There the Court rejected a claim that an ordinance prohibiting industrial uses in areas zoned for residential use was "unreasonable and confiscatory,"266 stating in part:

[T] he exclusion is in general terms of all industrial establishments, and it may thereby happen that not only offensive or dangerous industries will be excluded, but those which are neither offensive nor dangerous will share the same fate. But this is no more than happens in respect of many practice-forbidding laws which this Court has upheld although drawn in general terms so as to include individual cases that may turn out to be innocuous in themselves. ... [W] are not prepared to say that the end in view was not sufficient to justify the general rule of the ordinance, although some industries of an innocent character might fall within the proscribed class. ${ }^{267}$

Thus, the Court concluded that lawmakers may act on the basis of reasonable generalizations of what constitutes wrongful conduct. ${ }^{268}$

But what about instances in which the lawinakers' generalizations of wrongdoing are not reasonable? Hodel v. Irving ${ }^{269}$ could be explained as a case in which a taking occurred because the lawinakers intentionally deprived the claimants of their property based on an unreasonable generalization of wrongdoing. The Court held that a federal statute prohibiting the devise or descent of small undivided interests in certain Indian land was a taking of the decedents' property. The majority assumed that it would have been permissible for Congress "to prevent the owners of [these imterests] from further dividing them among future heirs on pain

265. 272 U.S. 365 (1926).

266. Id. at 386.

Although it was not entirely clear whether the Court in Village of Euclid was rejecting a takings clause challenge as well as a substantive due process challenge, the Court now consistently cites Village of Euclid as a takings clause decision. See, e.g., Keystone Bituminous Coal Ass'n v. DeBenedictis, 480 U.S. 470, 490 (1987); Kirby Forest Indus. v. United States, 467 U.S. 1, 15 (1984); Agins, 447 U.S. at 261; PruneYard Shopping Center v. Robins, 447 U.S. 74, 81 (1980); Penn Central Transp. Co. v. New York City, 438 U.S. 104, 125, 131, 134-35 (1978).

267. Village of Euclid, 272 U.S. at 388-89 (emphasis added). The Court remarked that the legislature might use general categories "to insure effective enforcement" or because "in soine fields, the bad fades into the good by such insensible degrees that the two are not capable of being readily distinguished and separated in terms of legislation." $I d$.

268. That is, so long as the lawinakers reasonably concluded that the public would usually consider the prohibited conduct to be wrongful, no taking occurs.

Compare Epstein's view that in takings cases the Court should require a very close fit between the government's ends and its ineans and should consider whether the government's ends could be achieved by a less restrictive alternative. R. EPSTEIN, supra note 28, at 128-29. Epstein argued, for example: "There is no obvious need to segregate residential from commercial areas. The police power has always functioned where the two were integrated, and there is no obvious connection between the degree of separation and the degree of injury avoided. Any desired separation can be achieved by private means." Id. at 132 . In many cases, application of Epstein's "less restrietive alternative" test would lead to the conclusion that the challenged law effected a taking.

269. 481 U.S. 704 (1987). 
of escheat."270 But the statute Congress enacted was not so closely tailored to the problem that Congress sought to address. ${ }^{271}$ One reason the Court gave for holding that the statute effected a taking was that "[the] statute effectively abolishes both descent and devise of these property mterests even when the passing of the property to the heir might result in consolidation of the property - as for imstance when the heir already owns another undivided interest in the property."272 Thus, one could say that the statutory category mcluded enough cases in which there was no plausible claim of wrongdoing that the Court considered it unreasonable of Congress to generalize that the proscribed conduct would be considered wrong by the public. ${ }^{273}$

If the lawmakers' generalization of wrongdoing is unreasonable (because in a substantial number of cases the lawmakers could not reasonably behieve the public would consider the proscribed conduct to be wrong), does that mean the statute effects a taking in every case to which it apphies? Or does it ouly effect a taking in those cases that prove the generalization to be unreasonable? There is a strong argument that "justice and fairness" would not require the government to compensate $A$ if the lawmakers made a judgment that $A$ 's conduct would be considered wrong by the public, and that judgment was reasonable with respect to $A$. The case law, however, does not provide a basis for summarizing the pattern the Court's takings cases have taken on this point. As discussed below, Connolly v. Pension Benefit Guaranty Corp. ${ }^{274}$ and Ruckelshaus v. Monsanto Co. ${ }^{275}$ support the view that $A$ is not entitled to receive compensation in such a case, while Hodel v. Irving arguably supports the opposite conclusion.

In Connolly, the Court rejected a facial takings challenge to the Multiemployer Pension Plan Amendments Act of 1980 (MPPAA). ${ }^{276}$ The MPPAA imposed liability on employers withdrawing from multiemployer pension plans in order to provide adequate funding for vested pension benefits. The Court stated that it was not persuaded that "fairness and justice require the public, rather than the withdrawing employers and other parties to pension plan agreeinents, to shoulder the responsibility for rescuing plans that are in financial trouble."277 It stressed that

270. Id. at 718 .

271. Congress apparently was concerned that extreme fractionation of ownership generated high administrative costs and that the land was not being put to productive use because of the difficulties of managing property held by a large number of owners.

272. Hodel v. Irving, 481 U.S. at 716 (emphasis added).

273. A claim of wrongdoing would be implausible where passing on an interest in the land would lead to consohdation, rather than fractionation, of ownership of the land.

274. 475 U.S. 211 (1986).

275. 467 U.S. 986 (1984).

276. Pub. L. No. 96-364, 94 Stat. 1208 (codified at 29 U.S.C. $\$ \S 1381-1461$ (1982)).

277. Connolly, 475 U.S. at 227. 
liability was being imposed because of the employer's past relationship to the pension plan:

The assessment of withdrawal hability is not made in a vacuum, however, but directly depends on the relationship between the employer and the plan to which it had made contributions. . . . There is nothing to show that the withdrawal liability actually imposed on an employer will always be out of proportion to its experience with the plan . . . 278

The Court's remarks could be seen as reflecting a judgment, based on the information presented to the Court, that Congress could reasonably have concluded that the public would consider it wrong of these employers not to inake the payments required by the statute, since the payinents would help solve a problem for which the employers were in some sense responsible. $^{279}$ That is, one could say that Congress made a generalization of wrongdoing or moral responsibility, and the Court concluded, on the basis of the evidence presented, that the generalization was reasonable.

What if the evidence had shown that the generalization of wrongdoing was unreasonable? Would the MPPAA then have effected a taking in every case to which it apphied? Justice O'Connor addressed this issue in a concurrence joined by Justice Powell. Justice O'Connor expressed concern that the statute might ultimately be interpreted as imposing liability on many employers wlio could not reasonably be viewed as responsible for the problem the statute sought to address. ${ }^{280}$ She argued that if that proved to be true, the Court should hold that the apphication of the statute effected a taking as to those particular employers. She seemed to assume that a claimant would liave to establisli not only that the generalization of wrongdoing was uureasonable, but also that the judgment of

278. Id. at 225-26. The Court made this statement after acknowledging that the statute "completely deprives an employer of whatever amount of money it is obligated to pay to fulfill its statutory liability." Id. at 225. As part of its three-factor Penn Central test, the Court was discussing the "severity of the economic impact" of the statute on employers. Id. Yet the Court naturally turned to the government's justification for forcing the claimants to pay this sum of money.

279. Compare this to a case like Nollan, where the Court did not view the Nollans as causing the problem they were being asked to solve. See supra text accompanying notes 202-06.

280. Justice O'Connor stated:

In my view, imposition of this type of retroactive liability on employers, to be constitutional, inust rest on some basis in the einployer's conduct that would make it rational to treat the employees' expectations of benefits under the plan as the employer's responsibility.

$\cdots$

The degree to which an employer can be said to be responsible for the promise of benefits made by a plan varies dramatically across the spectrum of plans. . . .

$\cdots$

... [W]hatever promises a collectively bargained plan makes with respect to benefits may not always be rationally traceable to the einployer's conduct and ... it may sometimes be quite fictitious to speak of such plans as "promising" benefits at a specified level, since to do so ignores express and bargamed-for conditions on those proinises.

Connolly, 475 U.S. at 229, 232, 235. 
wrongdoing was unreasonable in the claimant's particular case. ${ }^{281}$

Ruckelshaus v. Monsanto Co. ${ }^{282}$ can also be analyzed in these terms. Monsanto can be viewed as a case in which Congress determined that the public would consider it wrong to market pesticides without providing the public with the information it needs to judge the health and safety risks posed by the pesticides, and therefore Congress autlorized the EPA to disclose to the public much of the health and safety data submitted by pesticide manufacturers. ${ }^{283}$ Congress authorized such public disclosure even for data submitted when the statute had promised confidentiality. As discussed more fully below, the result reached in Monsanto could be explained by saying that the Court considered Congress' judgment of wrongdoing to be reasonable in some circumstances but not in others. When public disclosure would conflict with an express guarantee made to the clamiant, the Court considered the judgment of wrongdoing to be unreasonable. ${ }^{284}$ In other cases, the Court considered the judgment of wrongdoing to be reasonable. The Court held that a taking occurred only in those cases in which the express guarantee was violated-that is, only in those cases in which the judgment of wrongdoing was unreasonable. Viewed in this manner, Monsanto stands for the proposition that if an overly broad generalization of wrongdoing is inade by the lawmakers and the judgment of wrongdoing is reasonable in some cases, no taking occurs in those cases.

Next, consider Hodel v. Irving. ${ }^{285}$ If that decision is viewed as resting on the conclusion that Congress used an overly broad generatization of wrongdomg, ${ }^{286}$ then it stands for the proposition that if a generalization of wrongdoing is unreasonable, everyone to whom the law applies has suffered a taking. Justice Stevens expressed concern over this aspect

281. This is consistent with the majority's rejecting a facial challenge because it could not be shown that "the withdrawal hability actually imposed on an employer will always be out of proportion to its experience with the plan." Id. at 226 (emphasis added). Thus, the majority apparently assumed that the law would not effect a taking in every case if the generalization of wrongdoing proved to be unreasonable.

282. 467 U.S. 986 (1984).

283. The 1978 amendments to FIFRA, discussed at supra text accompanying note 93, authorized disclosure of infornation that would reveal "manufacturing or quality control processes" or certain details about "deliberately added inert ingredient[s]" only if "the Administrator has first determined that the disclosure is necessary to protect against an unrcasonable risk of injury to health or the environment." Pub. L. No. 95-396, §15(2)(d)(1), 92 Stat. 819, 830 (currently codified as amended at 7 U.S.C. $\S 136 \mathrm{~h}$ (d)(1) (1988)). Thus, Congress apparently judged that somewhat greater harm to the public would have to be threatened before the public would consider it wrong not to disclose this mformation.

284. As discussed at infra text aceompanying notes 328-31, the government's promise of nondisclosure affected whether the lawmakers could reasonably conclude that it would be wrong of the manufacturers to market their pesticides without letting the EPA pubhicly disclose the data they had submitted.

285. 481 U.S. 704 (1987).

286. See supra text accompanying notes 269-73. 
of Hodel v. Irving. He argued that the majority should not have rested its holding on the fact that the statute applied even when greater fractionation of ownership would not result from passing on the decedent's interest in the land, since greater fractionation would have resulted in the claimants' cases. ${ }^{287}$

In summary, the takings clause does not require individual assessments of wrongdoing. Rather, it permits lawinakers to act on the basis of reasonable generalizations of wrongdoing. Thus, a claimant cannot establish a taking simply by showing that her case would be an exception to a reasonable generalization of wrongdoing. If the lawinakers' generalization of wrongdoing is unreasonable, the Court's takings decisions are not clear on whether the statute effects a taking in every case to which it apphies. However, Monsanto and Justice O'Connor's concurrence in Connolly support the view that $A$ not only must establish that the generalization of wrongdoing was unreasonable, but she also must establish that the lawmakers' judgment of wrongdoing was unreasonable as apphied to her particular case.

\section{H. Facial and As Applied Takings Challenges}

As discussed in Part I, the Supreme Court has stated that a different standard should be used when a land-use regulation is challenged "on its face" than when it is challenged "as applied."288 According to the Court, the "no economically viable use" test should be used for facial challenges, while the three-factor Penn Central test should be used for "as applied" challenges. ${ }^{289}$ Yet the Court has not explained why the nature of its inquiry should differ depending upon whether the clain is that a law effects a taking in all cases to which it applies or that it effects a taking in a particular case to which it apphies. ${ }^{290}$ Moreover, the Court has not even consistently followed its announced rule that the Penn Central test should be used for as apphied challenges, while the "no eco-

287. 481 U.S. at 724 (Stevens, J., concurring in the judgment). Justice Stevens quoted the Court's statement in United States v. Raines, 362 U.S. 17, 21 (1960), that "one to whom application of a statute is constitutional will not be heard to attack the statute on the ground that impliedly it might also be taken as applying to other persons or other situations in which its application inight be unconstitutional." Hodel v. Irving, 481 U.S. at 725.

288. See Peterson I, supra note 4, at 1360-61.

289. See, e.g., Hodel v. Virginia Surface Mining \& Reclamation Ass'n, 452 U.S. 264, 295-96 (1981).

290. See Peterson I, supra note 4, at 1361. Suppose, for example, the Court concluded that a compensable taking oceurs whenever the government prevents the claimant from obtaining any "economically viable use" of a tangible thing. Then it would seem that $A$ would challenge a law "on its face" by arguing that the law deprives owners of all economically viable use of their things in all cases to which it applies, while she would challenge the law "as applied" by arguing that the law would deprive her of all economically viable use of a thing in the particular circuunstances of her case. 
nomically viable use" test should be used for facial challenges. ${ }^{291}$

The takings cases could be explained in a far inore coherent inanner by saying that whether a law is challenged on its face or as applied, the critical issue is whether the government is intentionally depriving private parties of their property to prevent or punish wrongdoing. If one focuses on the government's justification for its action, a law could effect a taking "on its face" for a number of reasons. It could be that the lawnakers plainly did not make a judgment of wrongdonig. In Lynch v. United States, ${ }^{292}$ for example, the proffered justification for reneging on the insurance contracts was sinply to save money. ${ }^{293}$ Or the lawinakers could have prohibited a general category of conduct that could not reasonably be regarded as wrongful in any case to which the law apphed. ${ }^{294}$

A law could also effect a taking "as applied" for a nuinber of reasons. The lawinakers could have adopted an overly broad generalization of wrongdonig, thereby effecting a taking in those cases in which the judginent of wrongdoing was unreasonable as applied to $A$. Monsanto ${ }^{295}$ is an exainple of an "as applied" challenge to an overly broad generalization of wrongdoing. ${ }^{296}$ Or a law miglit authorize an administrative agency or other governmental official to determine whetlier it would be wrong of $A$ not to give up her property, and that individualized judginent of wrongdoing might be unreasonable. ${ }^{297}$ Or a law iniglit authorize an administrative agency to require $A$ to give up her property either to prevent or punisli wrongdoing by $A$ or to proinote tlie common good, and the agency night require $A$ to give up her property snnply to promote the common good. ${ }^{298}$

If the law at issue required an administrative agency or other gov-

291. Id.

292. 292 U.S. 571 (1934).

293. See supra text accompanying notes $197-200$.

294. This assumes that a law embodying an unreasonable generalization of wrongdoing effects a taking only in those cases in which the judgment of wrongdomg is unreasonable as applied to the claimant. See supra text accompanying notes $274-87$.

295. 467 U.S. 986 (1984).

296. As discussed at supra text accompanying notes 282-87, Monsanto supports the view that if $A$ were to challenge a generalization of wrongdoing as overly broad, she would have to establish that the judgment of wrongdoing was unreasonable as applied to her. Hodel $v$. Irving, however, arguably supports the position that when a generalization of wrongdoing is overly broad, the law effects a taking in every ease to which it applies. If that were true, then $A$ could bring a facial challenge to an overly broad generalization of wrongdoing.

297. Nollan v. California Coastal Commission, 483 U.S. 825 (1987), might be read as a case in which the Court concluded that any judgment of wrongdoing that the Coastal Commission had made was unrcasonable. At times, however, the Court suggested in Nollan that no judgment of wrongdoing had been made. See supra text accoinpanying notes 202-06 \& 259-60.

298. For example, if a zoning ordinance granted an administrative agency the authority to determine whether a proposed land use would "promote the general welfare," and tlie agency denied $A$ permission to build on her land simply because the agency believed that the public would benefit from retaining $A$ 's land as open space, $A$ could argue that the agency had determined only that it 
ernmental body to make an individualized determination whether to require $A$ to give up her property, a challenge to that law would not necessarily be a challenge to the law "as applied." For example, a facial challenge could be brought if the lawinakers only authorized the administrative agency to determme whether it would promote the common good to require $A$ to give up her property and did not authorize the agency to make a judgment of wrongdoing, for then a taking would occur in every case to which the law applied. Perhaps such an argument could have been raised in Penn Central, ${ }^{299}$ for some of the legislative history quoted by the Court suggests that the lawmakers were only concerned about the desirability of preserving landmarks. ${ }^{300}$ Similarly, a taking would occur in every case to which the law applied if the lawmakers made a judgment that a certam category of conduct was undesirable (rather than wrongful) and then authorized the administrative agency to determine whether $A$ 's conduct fell into that category. ${ }^{301}$ Perhaps such an argument could have been raised in Nollan. The Califorma Coastal Act required the Coastal Commission to exact lateral public beach access before permitting "new developinent" along the coast, unless certain defined circumstances were found to exist. One could argue that the Coastal Act did not authorize the Coastal Commission to make a pohicy judgment as to when lateral public beach access should be required, but simply required the Coastal Cornmission to implement the legislature's pohicy judgment. Moreover, that judginent arguably turned solely on a determination that providing public beach access would promote the common good, not that it would be wrong of landowners not to provide public beach access. ${ }^{302}$

would promote the common good to deny $A$ the right to build, rather than that it would be wrong of $A$ to build.

299. 438 U.S. 104 (1978).

300. For example, the Court stated:

The city believed that comprehensive measures to safeguard desirable features of the existing urban fabric would benefit its citizens in a variety of ways: e. g., fostering "civic pride in the beauty and noble accomplishments of the past"; . . . "support[ing] and stimul[ating] business and industry"; . . . and promoting "the use of historic districts, landmarks, iuterior landmarks and sceric landmarks for the education, pleasure and welfare of the people of the city."

Penn Central, 438 U.S. at 109 (quoting New York CITY, N.Y., AdMin. Code ch. 8-A, § 205-1.0(b) (1976)). Thus, perhaps one could argue that the legislative history demonstrated that in fact no judgment of wrongdoing had been made by the lawmakers, even if a judgment of wrongdoing could plausibly have been made. See supra text accompanying notes 177 \& 207-10.

301. In some cases, the role of the administrative agency is to make factual determinations, not to make policy judgments (whether judgments of desirability or of wrongdoing).

302. The Califormia Coastal Act provided: "Public access ... along the coast shall be provided in new development projects except where (1) it is inconsistent with public safety, military security needs, or the protection of fragile coastal resources, (2) adequate access exists nearby, or (3) agriculture would be adversely affected." CAL. PUB. RES. CODE $\$$ 30212(a) (West 1986). The Califormia Court of Appeal found that the Nollans' proposed home constituted "new development" under the statute, and that none of the exceptions to the access requirement applied. Nollan v. 
Thus, if the Court were to decide takings cases using the principles articulated in this Article, it would focus on the saine issues whether a law was challenged "on its face" or "as applied." The Court would in all cases ask whether the government was intentionally depriving $A$ of her property to prevent or punish wrongdoing, or whether it was simply seeking to proniote the common good. In sone cases this inquiry would require the Court to consider the facts of $A$ 's individual case, while in other cases a facial challenge would be possible. However, the fundainental nature of the inquiry would remain constant.

\section{Governmental Commitments}

\section{Takings Clause Cases Involving Governmental Commitments}

A special category of takings decisions consists of cases in which the governnient first niade a promise to $A$ and then enacted a law reneging on that proimise. The Court often finds a taking in such cases. ${ }^{303}$ In Monsanto, ${ }^{304}$ for example, it formd a taking when the government, after making an "exphicit guarantee" that it would not disclose certain data, enacted a law authorizing the EPA to renege on that commitment.

Under the principles articulated in this Article, governmental pron1ise cases would be analyzed in the following way. When the lawinakers grant $A$ an econormically valuable legal right and make a promise that the right will not be eliminated, $A$ acquires property in the form of a "vested" economically valuable legal right. If the lawniakers later intentionally deprive $A$ of that property solely to pronote the common good, a conipensable taking occurs. No taking occurs, however, if they do so because they reasonably beheve the public would consider it wrong of $A$ not to give up her vested right. ${ }^{305}$

Just as we consider it wrong of private parties to break their promises without sufficient justification, in inany cases we consider it

California Coastal Comm'n, 177 Cal. App. 3d 719, 724, 223 Cal. Rptr. 28, 31 (1986), rev'd on other grounds, 483 U.S. 825 (1987).

The language of section 30212(a), which provides some evidence of the lawmakers' purpose, suggests that the lawmakers were concerned about increasing public access without damaging the environment or agriculture or endangering public safety. But this goes to the desirability of increasing public access, not to the wrongfulness of building on beachfront land without granting a lateral beach access easement.

303. Such cases may also raise contract clause issues. See infra text accompanying notes 33244.

304. 467 U.S. 986 (1984).

305. More specifically, if the lawmakers reasonably beheve the public would consider it wrong of $A$ not to give up her vested right without receiving compensation at fair market value, the government is depriving $A$ of her property to "prevent wrongdoing" and no taking occurs. In addition, no taking would occur if the lawmakers were depriving $A$ of her vested right to punish her for conduct that they reasonably believed the public would consider wrongful. 
wrong of the government to renege on its commitments. ${ }^{306}$ There are circumstances, however, in which we would consider a breach of proinise by the government to be justified. For example, suppose the governinent granted $A$ a vested right to build at a certain location. If the government later discovered that it would be unsafe to build at that location, the lawmakers could reasonably conclude that the public would consider it wrong of $A$ not to give up her vested right to build, rather than considering it wrong of the government to renege on its commitment.

If one exammes a number of Supreme Court takings cases in which the government broke a promise to $A$, one finds that in some cases the Court's analysis is quite similar to that offered here. In other cases, the analysis differs, yet the principles articulated in this Article could be used to explain the result reached by the Court. In Lynch v. United States, ${ }^{307}$ for example, the government issued disability and life insurance contracts to veterans under the War Risk Insurance Act and later sought to renege on its commitment by enacting a statute repealing "all laws granting or pertaining to yearly renewable term insurance." 308 The Court first determimed that the government had granted the veterans property rights within the meaning of the takings clause, stating that although the government had entered into these agreements with the veterans for "benevolent purposes,"309 it had made a commitment to the policy holders. These rights were not merely "gratuities [that could] be redistributed or withdrawn at any time in the discretion of Congress," but were "vested rights."310 The Court then considered the government's justification for depriving the veterans of those rights. Basically, the government's justifcation was that it wanted to save money. Congress did not even suggest that it would be wrong of the veterans not to give up their rights under the insurance contracts. ${ }^{311}$ The Court concluded that it was wrong of the government to break its promise:

"The United States [is] as much bound by [its] contracts as are individuals. If [the United States government] repudiates [its] obligations, it is as much repudiation, with all the wrong and reproach that term implies, as

306. For example, suppose the government made a commitment to $A$ and others to pay them certain retirement benefits, and later reneged on that commitment simply because it wished to use the money for other public projects. Here most people would probably conclude that it was wrong of the government to renege on its commitment.

307. 292 U.S. 571 (1934).

308. Id. at 575 .

309. Id. at 576 .

310. Id. at 577. The Court explained that the terms of the government's bargain were to be found in the authorizing statute and regulations promulgated under it and in the insurance policies themselves, and that "no power to curtail the amount of benefits which Congress contracted to pay was reserved to Congress; and none could be given by any regulation promulgated by the Administrator." Id. at 577-78.

311. Nor did Congress purport to be depriving the veterans of their rights to punish them for having acted wrongfully in the past. 
it would be if the repudiator had been a State or a municipality or a citizen." 312

Thus, one could explain Lynch by saying that the government intentionally deprived the claimants of their vested rights solely to proinote the common good, not because Congress reasonably beheved the public would have considered it wrong of the veterans not to give up their rights. Thus, a taking occurred.

United States $v$. Sioux Nation of Indians ${ }^{313}$ can also be explained as a case in which the Court found a taking because the government reneged on a commitınent that had created vested rights. In the Fort Laraime Treaty, ${ }^{314}$ the United States pledged that the Great Sioux Reservation, including the Black Hills, would be "set apart for the absolute and undisturbed use and occupation of [the Sioux]." "315 Eventually "the Executive Branch . . . decided to abandon the Nation's treaty obligation," withdraw the U.S. Army froni its role as enforcer of the treaty, and allow settlers to nove into the Black Hills." In time, " $[t]$ he Government concluded that the only practical course was to secure to the citizens of the United States the right to mine the Black Hills for gold." 317 Congress did so by enacting a law abrogating the Fort Laramie Treaty. ${ }^{318}$ The Sioux asserted that this breach of the government's pron1ise was a taking, and the Court agreed. ${ }^{319}$ The only issue, as the Court saw it, was whether Congress, in enacting the challenged law, had acted in its capacity as a "guardian" of Indian property. The Court concluded that Congress had not acted in that role, ${ }^{320}$ and thus had committed a taking. Viewed within the frannework provided in this Article, a taking occurred ni Sioux Nation because the government enacted a law that deprived the Sioux of their rights to the Black Hills, with no plausible claim that it would have been wrong of the Sioux not to give up those rights. The government simply took the Sioux's rights because it wanted thein.

312. Lynch, 292 U.S. at 580 (quoting Sinking-Fund Cases, 99 U.S. 700, 719 (1879)). The Supreme Court has subsequently explained that it was wrong of the government to seek to renege on its commitment solely to save money. See, e.g., Bowen v. Public Agencies Opposed to Social Sec. Entrapment, 477 U.S. 41, 55 (1986) (citing Lynch for the proposition that Congress may not repudiate its own debts, which constitute property to the lender, simply in order to save money); United States Trust Co. v. New Jersey, 431 U.S. 1, 26 n.25 (1977) (citing Lynch for the proposition that the "need for money is no excuse for repudiating contractual obligations").

313. 448 U.S. 371 (1980).

314. April 29, 1860, United States-Sioux Nation, 15 Stat. 635.

315. Sioux Nation, 448 U.S. at 374 (quoting the Fort Laramie Treaty, 15 Stat. 635, 636).

316. Id. at 378 .

317. Id.

318. Id. at 382 .

319. Id. at 423-24.

320. As the Court expressed it, "Spoliation is not management." Id. at 408 (quoting Shoshone Tribe v. United States, 299 U.S. 476, 498 (1937)). 
Now let us consider a takings clause case in which the challenged law prohibits $A$ from building a particular structure, such as an office building, on her land. Would it strengthen $A$ 's taking claim if the government had promised $A$ that she could construct an office building on her land? ${ }^{321}$ Under the principles offered in this Article, if the government had simply prohibited $A$ from building, it would have deprived her of "type one" property. 322 This would be a taking unless the lawmakers reasonably beheved the public would consider it wrong of $A$ not to surrender her freedom to build. As we have seen, the "wrongdoing" test is sufficiently weak that this burden could easily be met in many circumstances-for example, if $A$ wished to construct an office building in a residential area. ${ }^{323}$ But, if the government first granted $A$ a vested right to build, and then enacted a law reneging on that commitment, the government would have deprived her of "type two" property as well as "type one" property. ${ }^{324}$ The question with respect to type two property would agam be whether the lawmakers reasonably believed the public would consider it wrong of $A$ not to give up her property. But, in a case where the government is reneging on a promise, the wrongdoing test would be more difficult to meet for several reasons. First, we attach significance to a promise. Normally, we consider it wrong to break a promise. Thus, we normally would consider it wrong of the government to renege on its commitment to let $A$ build, rather than considering it wrong of $A$ not to give up her vested right to build. Second, when the government granted $A$ a vested right to build, it presumably determmed that $A$ 's proposed conduct was not wrongful. It would be difficult to establish that such conduct shonld later be considered wrongful without showing that circumstances or values had changed. ${ }^{325}$ Third, the government's promise may have induced reliance by $A$. If $A$ reasonably relied to her detriment on the government's promise, it would be even more difficult to conclude that it would be wrong of $A$ not to give up her vested right to build. ${ }^{326}$

No Supreme Court case addresses the specific situation described above. In the one case in which a government deprived the claimant of a vested right to build, the Court did not resolve the takings issue. ${ }^{327}$

321. For example, the government might have granted $A$ a vested right to build the office building and then enacted a law reneging on that commitment. Vested rights to build are discussed at supra note 71 .

322. See supra text accompanying notes 39-42 (defining "property").

323. See supra text accompanying notes 216-17.

324. See supra text accompanying notes $39-42$.

325. The issue of changed circumstances is discussed more fully at infra text accompanying note 524.

326. The issue of reliance is discussed more fully at infra text accompanying notes 525-30.

327. In Williamson County Regional Planning Commission v. Hamilton Bank, 473 U.S. 172 (1985), the claimant argued that under state law it had acquired a "vested right" to develop a tract of land in accordance with plans previously approved by the Williamson County Regional Planning 
Monsanto, ${ }^{328}$ however, supports the general point of the vested-right-tobuild hypothetical. That is, Monsanto supports the notion that it would be easier to establish a taking if the government first proinised $A$ that she could act in a certain manner and then reneged on that commitinent, than if the government simply prohibited $A$ froin engaging in the same conduct.

In Monsanto, the Court held that a taking would occur if the EPA publicly disclosed certain health and safety data that had been submitted when FIFRA “explicitly guaranteed" confidentiahty, but that no taking would occur if the EPA disclosed data that had been submitted at other times. ${ }^{329}$ Although the Court did not analyze the case in this manner, one could say that two types of "property" were at issue in Monsanto.

First, wholly apart from the government's promise of confidentiality, Monsanto claimed that a taking occurred when the government deprived it of its economically valuable freedom to market its pesticides without making certain health and safety data available to the public. The Court rejected that claim. Although it did not do so, the Court could have justified that rejection on the ground that where no promise of nondisclosure had been made, Congress could reasonably have concluded that the public would consider it wrong of pesticide inanufacturers to market their products without making this information available to the pubhic.

Second, Monsanto argued that a taking occurred because the government reneged on a promise to keep certain data confidential. Here the Court could have said that the promise created a vested, economically valuable legal right to require the government to keep the data confidential. The government deprived Monsanto of that property when it authorized the EPA to disclose the data. The issue before the Court, then, was whether Congress could reasonably have concluded that the public would consider it wrong of Monsanto and other pesticide manufacturers not to give up that vested right. ${ }^{330}$ The result in Monsanto could be explained by saying that the Court considered such a judgment of wrongdoing to be unreasonable. The governinent had a heavier burden of justification because it had promised that the data would not be disclosed. In finding a taking, the Court stressed that the government

Commission, and that the county's refusal to permit such development was a "taking" of the claimant's vested right. The Court did not resolve whether the county had deprived the claimant of a vested right to build and, if so, whether this constituted a taking, since the Court decided that the takings claim was not yet ripe.

328. 467 U.S. 986 (1984).

329. Monsanto is discussed at supra text accompanying notes $92-102,113-22$, and 282-84.

330. Since the Court had decided that the government would not commit a taking by publicly disclosing the data where there had been no promise of nondisclosure, the issue was whether the government's promise of nondisclosure should change the Court's resolution of the takings issue. 
had made an "exphicit guarantee" to Monsanto and was now seeking to break that promise, and that Monsanto had relied on the government's exphicit guarantee when it submitted the data to the EPA. Thus, the fact that the government was breaking a promise proved to be critical in determining whether a taking occurred. ${ }^{331}$

\section{The Relationship Between Contract Clause Cases Involving Governmental Commitments and Takings Clause Cases Involving Governmental Commitments}

In many takings clause cases involving the government breaking a promise, the clamiant could also raise a claim under the contract clause. ${ }^{332}$ I will not attempt to explore fully the relationship between the Supreme Court's contract clause decisions involving governinental commitments and its takings clause decisions involving governınental commitments. I will limit myself to two observations. First, it appears that im the contract clause cases, as in the takings clause cases, it is significant whether the government reneged on its commitment simply to promote the common good, or whether the government was seeking to prevent wrongdoing. Second, the Court's statement in contract clause cases that the government cannot "bargain away the police power" can be harmonized with my analysis of takings decisions involving governmental promises.

Stone v. Mississippi ${ }^{333}$ illustrates both points. In that case, the state legislature issued a corporate charter to $A$, which bound the government to permit $A$ to run a lottery for twenty-five years. Subsequently, a state constitutional provision was adopted stating that all lotteries, even those previously authorized, were to be prohibited. The state legislature enacted a statute enforcing the constitutional mandate. The Supreme Court held that neither the state constitutional provision nor the statute violated the contract clause. The Court first emphasized that lotteries were considered immoral ("a species of gambling, and wrong in their influences"334) and then said that although the state legislature appeared to have made a binding commitment to permit $A$ to operate a lottery for

331. I do not mean to suggest that the government could never justify breaking its promise to $A$. For example, the Court surely would not have found a taking in Stone v. Mississippi, 101 U.S. 814 (1880) (discussed at infra text accompanying notes 333-35), where the government reneged on its commitment to permit $A$ to run a lottery because the public concluded that lotteries were immoral.

332. The contract clause provides: "No State shall ... pass any . . . Law impairing the Obligation of Contracts." U.S. CONST. art. I, § 10.

333. 101 U.S. 814 (1880).

334. Id. at 821 . The Court also remarked that, absent the governmental promise, there was no question that the government could prohibit lotteries. The Court stated: "When the government is untrammelled by any claim of vested rights or chartered privileges, no one has ever supposed that lotteries could not lawfully be suppressed, and those who manage them punished severcly as violators of the rules of social morality." Id. at 818-19. 
twenty-five years, "[n]o Legislature can bargain away the public health or the public morals." 335

When the Court says in contract clause cases that the government cannot "bargain away the police power," 336 it sometimes seems to be saying that the government's purported commitment may later be wholly disregarded. The Court has stated that the commitment is "void $a b$ initio" because the government cannot "bargain away the police power." 337 Moreover, it has suggested that the proposition that the police power cannot be bargaimed away is derived from the nature of sovereignty, rather than simply being an interpretation of the contract clause. ${ }^{338}$ If that is true, the same proposition presumably would apply im takings clause cases involving governmental commitments. Yet this does not square with the Court's takings decisions. In Monsanto, ${ }^{339}$ for example, the Court held that a taking occurred when the government reneged on its explicit gnarantee. The government's commitment was not considered "void ab initio" and was not wholly disregarded. ${ }^{340}$

335. Id. at 819. The Court could have said that the lawmakers reasonably believed the public would consider it wrong of $A$ not to give up his right to operate a lottery, because lotteries were considered immoral.

336. See, e.g., United States Trust Co. v. New Jersey, 431 U.S. 1, 23 (1977) (quoting Stone, 101 U.S. 814, 817 (1880)).

337. For example, in United States Trust Co. v. New Jersey, 431 U.S. 1 (1977), the Court stated:

It is often stated that "the legislature cannot bargain away the police power of a State." ..

This doctrine requires a determination of the State's power to create irrevocable contract rights in the first place, rather than an inquiry into the purpose or reasonableness of the subsequent inipairment. In short, the Contract Clause does not require a State to adhere to a contract that surrenders an essential attribute of its sovereignty. [Such a contract is] invalid $a b$ initio.

Id. at 23. Similarly, in Stone the Court stated that since the charter clearly purported to bind the government to permit $A$ to run a lottery for 25 years, "[w] $w$ ther the alleged contract exists... or not, depends on the authority of the legislature to bind the State and the people of the State in that way. All agree that the legislature cannot bargain away the police power of a State." 101 U.S. at 817 (emphasis added).

338. In United States Trust, the Court stated that the contract clause does not require a State to adhere to a contract that surrenders "an essential attribute of its sovereignty." 431 U.S. at 23. Earlier cases developed this notion more fully. In Stone, for example, the Court stated: "No legislature can bargain away the public health or the public morals. . . Government is organized with a view to their preservation, and cannot divest itself of the power to provide for them." 101 U.S. at 819. Similarly, in Contributors to the Pennsylvania Hospital v. City of Philadelphia, 245 U.S. 20 (1917), the Court asserted:

[T] he States cannot by virtue of the contract clause be held to have divested themselves by contract of the right to exert their governmental authority in matters which from their very nature so concern that authority that to restrain its exercise by contract would be a renunciation of power to legislate for the preservation of society or to secure the performance of essential governmental duties.

Id. at 23.

339. 467 U.S. 986 (1984).

340. Yet the governnient had made a commitment that could have confiicted with the government's subsequent exercise of its "police power"-whether that term is used to mean the government's power to prevent or punish wrongdoing, or its power to promote the common good. See supra note 200 (discussing the term "police power"). 
These statements in contract clause cases regarding "bargaining away the police power" can be harmomized with takings clause cases like Monsanto if one reads tle contract clause cases as saying that the government always retains the power to prevent or punisli wrongdoing without paying just compensation; that power cannot be "bargained away." The government's commitment is still significant, however, for if the government enacts a law reneging on a governmental commitinent simply to promote the common good, the government inust pay just compensation. ${ }^{341}$

This interpretation is consistent with the Court's holding in United States Trust Co. v. New Jersey. ${ }^{342}$ In United States Trust, the State of New Jersey promised bondliolders that it would limit the ability of the Port Authority of New York and New Jersey to subsidize rail passenger transportation from revenues and reserves. The state legislature subsequently enacted a law reneging on that promise, seeking to facilitate the development of mass transit facilities and thus conserve energy and reduce pollution. The Supreine Court held that this law violated the contract clause. Unlike prior cases in which the state was exercising its reserved "pohice power," here the state simply sought to promote the common good:

Mass transportation, energy conservation, and environmental protection are goals that are important and of legitimate public concern. Appellees contend that these goals are so important that any harm to bondholders from repeal of the 1962 covenant is greatly outweighed by the public benefit. We do not accept this invitation to engage in a utilitarian comparison of public benefit and private loss. . . [A] State cannot

341. One type of land-use control that would be affected by my proposed interpretation of the Court's contract clause cases is the development agreement. A number of states have enacted legislation authorizing local governments to enter into agreements with land developers. Wegner, Moving Toward the Bargaining Table: Contract Zoning, Development Agreements, and the Theoretical Foundations of Government Land Use Deals, 65 N.C.L. REv. 957, $994-99$ (1987). These statutes often provide for a "regulatory freeze." That is, when the local government enters into a development agreement, it purports to bind itself (subject to certain exceptions) to permit the developer to carry out the project described in the agreement even if local land-use regulations later change in a manner that would have prohibited the project. Id. One of the issues that has been raised regarding development agreements is whether the courts will conclude that the government's commitment is unenforceable because the government was attempting to "bargain away the police power." See, e.g., Hagman, Development Agreements, in 1982 Zoning and Planning LAW HANDBooK 173, 186-95 (F. Strom ed. 1982); Holliman, Development Agreements and Vested Rights in California, 13 URB. L. 44, 53 (1981); Kramer, Development Agreements: To What Extent Are They Enforceable?, 10 REAL EST. L.J. 29, 39-45 (1981). Under my understanding of the contract clause cases, the commitment made by the government would not be wholly disregarded, either for contract clause purposes or for takings clause purposes. Thus, if the government sought to renege on a development agreement, the fact that the government had previously promised that the developer could complete the project would make it easier for the developer to prevail on a takings claim. Such a case would be analyzed in the same manner as a case involving revocation of a vested right to build. See supra text accompanying notes 321-26.

342. 431 U.S. 1 (1977). 
refuse to meet its legitimate financial obligations simply because it would prefer to spend the money to promote the public good rather than the private welfare of its creditors. ...

$\cdots$

... [A] State is not completely free to consider impairing the obligations of its own contracts on a par with other policy alternatives. ${ }^{343}$

The Court stated that if the state wished to acquire these contractual rights, it could exercise its power of eminent domam and pay just compensation to the bondholders.

Thus, when the government grants $A$ a vested economically valuable legal right, the government's commitment not to deprive $A$ of that right is not "void $a b$ initio" im the sense that the governmental commitment is wholly disregarded. If the government reneges on that commitment simply to promote the common good, it must pay $A$ just compensation. If, however, the government reneges on that commitment because the lawmakers reasonably beheve the public would consider it wrong of $A$ to hold the government to its commitment, no compensation need be paid. $^{344}$

\section{J. Civic Obligations}

Cases mvolving "civic obhigations" or "pubhic duties" are another special category of cases in which takings clamis might be raised. If the government requires $A$ to pay an income tax or to serve as a juror or to serve in the military, why is this forced deprivation of property not a taking? ${ }^{345}$

343. Id. at 28-29 (emphasis added). The Court contrasted the case before it with one in which the government was reneging on its commitment in order to protect the public health or safety: "[A] revenue bond might be secured by the State's promise to continue operating the facility in question; yet such a promise surely could not validly be construed to bind the State never to close the facility for health or safety reasons." Id. at 25 .

344. Compare the position taken by Epstein in Takings that if the state promises $A$ she can act in a certain manner for a stated period of time, the government must either adhere to that commitment or pay just compensation. Epstein asserted that even if $A$ 's conduct were causing significant harm to the public, the government, as representative of the people, would be bound by its commitment. R. EPSTEIN, supra note 28, at 150-51. Thus, Epstein would not entertain the possibility that in some circumstances it would be wrong of $A$ to hold the government to its commitment.

345. Many writers on the takings clause either fail to address this issue or consider it only in passing. Sax, for example, asserted at the close of Takings and the Police Power, that most taxes are not a taking because the burden is distributed broadly, just as it is when just compensation is paid. Sax I, supra note 147, at 76. He failed to analyze more narrowly based taxes, however, and did not discuss the draft or jury duty. In the case of the draft, the burden is not spread so broadly that the same result is achieved as when just compensation is paid.

In the chapters of Private Property and the Constitution on Ordinary Observing, Ackerman's only comment on taxation was that "[t]oday's judges are reformist only insofar as they will not challenge an official action on takings grounds if it is plainly motivated by redistributive concernsthus tax legislation is generally immune from serious scrutiny." B. ACKERMAN, supra note 66, at 109 (emphasis in original) (footnote omitted). Ackerman did not expand on this notion. Nor did he 
In many civic obligation cases, $A$ is being asked to contribute resources to an endeavor that benefits the public generally. Thus, $A$ is benefited as well as burdened by the law. Yet these cases cannot be explained by saying that no taking occurs because $A$ suffers no economic detriment, or that a taking occurs but $A$ receives just coinpensation in kind, for often $A$ clearly is giving more than slie gets in return. ${ }^{346}$ For example, taxes are sometimes imposed to fund governmental activities that clearly will provide no direct economic benefit to $A .^{347}$ Yet, it is now widely accepted that sucli a tax does not effect a compensable taking. ${ }^{348}$

The civic obligation cases can be explained by applying the moral justification principle. In each of these cases, the lawmakers could reasonably conclude that the public would consider it wrong of $A$ (and others) not to contribute their fair share. It is lielpful to consider these cases separately from otlier takings cases, however, for here the judgment of moral responsibility depends on viewing $A$ in lier role as a "citizen"that is, as a member of the political community. ${ }^{349}$

In most cases, when the government enacts a law that requires $A$ to give up lier property, it is enforcing moral norms of the community that

consider the possibility that there might be an "Ordinary justification" for taxation. Ackerman also did not explain why jury duty and the draft are not considered takings. It appears, however, that Ackerman's Ordinary Observer, who conceives of "property" as "things," would not see a forced deprivation of economically valuable services as a taking of a "thing."

346. As the Court remarked in Keystone Bituminous Coal Association v. DeBenedictis, 480 U.S. 470 (1987): "Not every individual gets a full dollar return in benefits for the taxes he or she pays; yet, no one suggests that an individual has a right to compensation for the difference between taxes paid and the dollar value of benefits received." Id. at 491 n.21.

347. Consider, for example, a rcal property tax imposed to fund the public school system, where $A$ has no children.

348. Epstein, however, concluded in Takings that progressive taxation effects a taking without payment of just coinpensation. First, Epstein asserted that taxation constitutes a taking because the government is requiring $A$ to pay money to the government, and that requirement is not within the "police power" (as defined by Epstein), because the government generally is not combatting force or fraud when it imposes a tax. Epstein then considered whether the taxpayer would receive "implicit in-kind compensation" from the programs funded by the tax. He concluded that she would not under a system of progressive taxation, and then argued that a flat tax on income is constitutionally required because it would minimize the expected mismatch between taxes paid and benefits received.

R. EPSTEIN, supra note 28, at 295-303.

Given this conceptual framework, it is not surprising that Epstein also stated that a taking without payment of just compensation would occur if tax money were spent on welfare. Again, he concluded that there would be a mismatch of taxes paid and benefits received. Epstein stated that although welfare payments may benefit the rich to some extent by reducing violence by the poor, "[t]he flrst defense against violence should be police measures, which can be modified as exigencies arise." Id. at 316 (footnote omitted).

Clearly, Epstein has no notion that $A$, as a member of a political community that chooses to provide for the poor, might have a moral obligation to pay her fair share of taxes, or that it might be considered fair to distribute the tax burden according to ability to pay.

349. The term "citizen" is not used literally. Although some "civic obligations" are imposed only on citizens, others apply to a somewhat broader range of individuals. For example, the federal income tax applies to resident aliens. I.R.C. $\$ 1$ (1988); Treas. Reg. $\S 1.1-1(\mathrm{a})(1)(1988)$. 
are not dependent on viewing $A$ in her role as a citizen. For example, if the government prohibits $A$ from using her land in a manner that would seriously harm surrounding residents, the government is preventing $A$ from engaging in behavior that is considered blameworthy wholly apart from the notion that $A$ has certain obligations as a citizen. Similarly, if the government requires $A$ to forfeit an object used in the commission of a crime, $A$ is being punished for behavior that is considered blameworthy wholly apart from $A$ 's role as a citizen. By contrast, in the case of a "civic obligation" like payment of imcome taxes, we consider it wrong of $A$ not to contribute her fair share because we view her as a member of the political community. Ordinarily, we do not consider it wrong of soineone not to contribute money to be spent for the benefit of third parties. Yet if we view $A$ as a member of the pohitical community, and if a decision has been made by that pohtical commumity to carry out a governmental program that benefits third parties, then we consider it wrong of $A$ not to pay her fair share to fund that program. ${ }^{350}$

Currently, the hist of civic obligations that require one to give up econoimically valuable resources is relatively short. The draft, jury duty, and payment of taxes are the primary iteins on the hist, although there are others. ${ }^{351}$ For example, one can be required to serve as a witness without being compensated for one's services at the market rate.

The Supreme Court has often described such obligations as "civic obligations" or "civic duties"-responsibilities that one bears as a member of the political community. For example, in the Selective Draft Law Cases, ${ }^{352}$ the Court stated tliat "tlie very conception of a just government

350. See generally Graves v. New York ex, rel. O'Keefe, 306 U.S. 466, 484 (1939) ("[T]he taxpayers enjoyed the benefit and protection of the laws of the United States and were uuder a duty, common to all citizens, to contribute financial support to the government ...."); Ford v. United States, 618 F.2d 357, 360 (5th Cir. 1980) ("[Olur taxing system is ... dependent for compliance in large part upon a sense of civic duty."); Rosenbloom v. United States, 699 F. Supp. 284, 286 (S.D. Fla. 1988) (criticizing taxpayers who "adnitted tax liability [yet] attempted to avoid their civic duty by taking advantage of clerical errors").

Once the political community of which $A$ is a member has decided to fund certain governmental programs to promote the common good, and has asked $A$ (and others) to contribute their fair share to fund those programs, we view $A$ as shirking a moral obligation if she refuses to pay her fair share. Thus, the political community's decisionmakiug process which leads to the enactment of the tax law gives rise to the moral obligation of $A$ (and other members of the political community) to pay the tax. Note, however, that the moral obligation is not established merely by showing that a law requires $A$ to pay a certain sum of money to the government.

351. In Takings, Epstein did not discuss the draft, jury duty, or other civic obligations that require $A$ to give up her economically valuable services. R. EPSTEIN, supra note 28. Presumably, Epstein did not address these obligations because he had determined that $A$ 's labor is not "private property" within the meaning of the takings clause. See supra note 52. In Proceedings of the Conference on Takings of Property and the Constitution, 41 U. MIAMI L. REV. 1 (1986), however, Epstein stated that if labor were considered "property" uuder the takings clause, the draft would effect a taking without payment of just compensation. Id. at 82 .

352. 245 U.S. 366 (1918). 
and its duty to the citizen includes the reciprocal obligation of the citizen to render military service in case of need and the right to coinpel it."353 The Court portrayed military service as a moral obligation of a citizen to contribute to an endeavor agreed upon by the political community. As the Court expressed it, military service is "[an] exaction by the government from the citizen of the performance of his supreme and noble duty of contributing to the defense of the rights and honor of the nation, as a result of a war declared by the great representative body of the people." ${ }^{354}$ Similarly, in Taylor v. Louisiana, ${ }^{355}$ the Court stated that " "sharing in the administration of justice [by serving on a jury] is a phase of civic responsibility." "356 Moreover, in Hurtado v. United States, ${ }^{357}$ the Court emphasized that one has a "public duty" to give testimony:

"[I]t may be a sacrifice of time and labor, and thus of ease, of profits, of livelihood. This contribution is not to be regarded as a gratuity, or a courtesy, or an ill-required favor. It is a duty not to be grudged or evaded. Whoever is impelled to evade or to resent it should retire from the society of organized and civilized communities and become a hermit."358

The Court in Hurtado specifically rejected the argument that a "taking" of property requiring the payment of just compensation occurs when the government compels the performance of a civic obligation. As the Court expressed it, "the Fifth Amendment does not require that the

353. Id. at 378 .

354. Id. at 390; see also Selective Serv. Sys. v. Minnesota Pub. Interest Research Group, 468 U.S. 841,854 (1984) (describing young inen who register with the Selective Service as "those who are willing to meet their responsibilities to the United States"); id. at 866 (Marshall, J., dissenting) (stating that "promoting full compliance with the registration law . . . in turn promotes fairness in allocatimg burdens in the event of reinstitution of involuntary imduction" and quoting Congress' statement that "[i]n a free society ... the obligations and privileges of serving in the armed forces and the reserve components thereof should be shared generally, in accordance with a systein of selection which is fair and just'" (quoting 50 U.S.C. app. $\$ 451(\mathrm{c})$ (1982))).

In Edwards v. Califorma, 314 U.S. 160 (1941), Justice Jackson emphasized that certain rights, as well as certain obligations, flow from one's national citizenship:

Duncan owes a duty to render military service, and this Court has said that this duty is the result of his citizenslip. ... Rich or penniless, Duncan's citizenship under the Constitution pledges his strengtl to the defense of California as a part of the United States, and his right to migrate to any part of the land he must defend is something she must respect under the same instrument.

Id. at 185-86 (Jackson, J., concurring).

355. 419 U.S. 522 (1975).

356. Id. at 531 (quoting Thiel v. Southern Pac. Co., 328 U.S. 217, 227 (1946) (Frankfurter, J., dissenting)); see also McDonough Power Equip., Inc. v. Greenwood, 464 U.S. 548, 553 (1984) ("[T]rials are costly, not only for the parties, but also for the jurors performing their civic duty ...."); Umited States v. Ruggiero, 846 F.2d 117, 128 (2d Cir. 1988) (Lumbard, J., dissenting) ("Jury service . . . entails many personal sacrifices and is compensated largely by the fulflllinent of an important civic duty."), cert. denied, 109 S. Ct. 491 (1988).

357. 410 U.S. 578 (1973).

358. Id. at 589 n.10 (quoting 8 J. Wigmore, EvidenCE $\$ 2192$, at 72 (J. McNaughton rev. 1961)). 
Government pay for the performance of a public duty."359 Focusing in particular on the civic duty of appearing before a court or grand jury to give testimony, the Court stated:

"[I]t is clearly recognized that the giving of testimony and the attendance upon court or grand jury in order to testify are public duties which every person within the jurisdiction of the Government is bound to perform upon being properly suininoned, and for performance of which he is entitled to no further coinpensation than that which the statutes provide."360

Just as it is difficult to offer a fornula for what constitutes "wrongdomg" im other contexts, it is difficult to summarize the factors that enter into a judgment of whether $A$ owes a "civic duty" to give up an economically valuable resource. At least one miportant factor to consider, however, is who must bear the burden imposed by the law.

In other contexts, the burden miposed by a law that mvolves a judgment of wrongdomg is often fairly narrowly distributed, because the moral justification for the law only apphies to a limited group of people. For example, a local government might require any developer who wishes to construct a new residential subdivision to dedicate land for a park. The government's rationale for this exaction is that the new subdivision will cause overcrowding of existing parks, harming the current residents. ${ }^{361}$ Here the burden of the exaction is narrowly based, yet there is a moral justification for the distribution of the burden.

The burden of civic obligations is distributed broadly because the moral justification for the law apphes to a broad group of people. While there is no set formula for fairly allocating the burdens of citizenship, we have coine to regard a progressive systein of income taxation as a fair method of distributing the burden of taxation. ${ }^{362}$ With jury duty, the basic rule we have adopted is that all who are qualified to serve as jurors must serve, although we make exceptions for cases in which service would involve unusual hardship. ${ }^{363}$ In the case of the draft, we have

359. Id. at 588. The Court cited, among other cases, United States v. Hobbs, 450 F.2d 935 (10th Cir. 1971), where the court rejected a takings clause challenge to the Selective Service Act. Hurtado, 410 U.S. at 589.

360. Hurtado, 410 U.S. at 589 (quoting Blair v. United States, 250 U.S. 273, 281 (1919)).

361. As discussed at supra text accompanying notes 216-21, one of the factors that enters into judgments of who is in the wrong in the case of conficting land uses is who was there first.

362. The current tax system is derived froin the Inconie Tax Act of 1913, ch. 16, 38 Stat. 166, enacted immediately following the adoption of the sixteenth amendinent, which provides that " $[t]$ he Congress shall have power to lay and collect taxes on inconies, from whatever source derived, without apportionment among the several States, and without regard to any census or enumeration." U.S. CONST. amend. XVI. The 1913 Act contained progressive features, with a normal tax rate of one percent and a surtax of one percent progressing to six percent. Galvin, History of the Substantive Tax Reform Project, in Studies In Substantive TAX Reform 3 (A. Willis ed. 1969). The rates increased stecply during World War I and have fluctuated since, but the basic progressive structure has remained intact. Id. at $3-4$.

363. See, e.g., 28 U.S.C. $\$ 1866(c)$ (1988) (authorizing courts to excuse jurors "upon a showing 
traditionally begun by limiting the pool to young 1 nen $^{364}$ who are qualified to serve in the military, ${ }^{365}$ and then have inade exceptions when service would involve unusual hardship or when an individual's civilian occupation is vital to the national interest. ${ }^{366}$ Within that pool, we have used various inethods of selection, based on contemporary views as to what selection inethod would be both "fair and just" and "consistent with the inaintenance of an effective national econoiny."367 In each case, we surely have not permanently settled on one fair inethod of distributing the burden of citizenship.

Tradition has a great deal to do with the fact that payinent of taxes, the draft, and jury duty are the primary civic obligations that are currently imposed. In theory, this hist could change significantly over tine. Indeed, the range of people who are expected to satisfy a particular civic

of undue hardship or extreme inconvenience, for such period as the court deems necessary"); CAL. Civ. Proc. CODE $\$ 204$ (b) (West Supp. 1989) (court "shall excuse a person from jury service upon finding that the jury service would eutail undue hardship on the person or the public served by the person").

364. See, e.g., Military Selective Service Act, 50 U.S.C. app. $\$ 453$ (1982) ("Except as otherwise provided in this title, it shall be the duty of every male citizen . . between the ages of eighteen and twenty-six, to present himself for and submit to registration."); id. app. \$ 454(a) (all eligible registrants between 18-1/2 and 26 are liable for inilitary training and service); Selective Training and Service Act of 1940, ch. 720, § 3(a), 54 Stat. 885, 886 (1940) (expired 1947) ("Except as otherwise provided in this Act, every male citizen ... between the ages of twenty-one and thirty-six at the time fixed for his registration, shall be liable for training and service.").

Although the fairness of drawing a line based on gender has been challenged under the equal proteetion clause, the Court has thus far rejected that challenge. See Rostker v. Goldberg, 453 U.S. 57 (1981). Justice Marshall, dissenting in Rostker, argued that women should not be "categorically exclude[d] from [this] fundamental civic obligation." Id. at 86 (Marshall, J., dissenting).

365. See, e.g., Military Selective Service Act, 50 U.S.C. app. § 454(a) (1982) ("No person shall be inducted into the Armed Forces for training and service ... until his acceptability in all respects, including his physical and inental fitness, has been satisfactorily determined under standards prescribed by the Secretary of Defense."); Selective Training and Service Act of 1940, ch. 720, § 3(a), 54 Stat. 885, 885 (1940) (expired 1947) ("[N]o man shall be inducted [until] his physical and mental fitness for [military] training has been satisfactorily determined.")

366. See, e.g., Military Selective Service Act, 50 U.S.C. app. $\$ 456$ (1982) (authorizing deferments for specific classes of individuals, including those whose induction would cause hardship to dependents and those whose civilian employinent is "necessary to the maintenance of the national health, safety or interest," and authorizing exemptions and alternative service requirements for conscientious objectors); Selective Training and Service Act of 1940, ch. 720, $\S 5,54$ Stat. 885, 88789 (1940) (expired 1947) (same).

367. Military Selective Service Act, 50 U.S.C. app. § 451(c) (1982). Congress has declarcd that "in a frce society the obligations and privileges of serving in the armed forces and the reserve components thereof should be shared generally, in accordance with a system of selection which is fair and just, and which is consistent with the maintenance of an effective national economy." Id. Congress has also provided, subject to certain additional restrictions, that

[t]he selection of persons for training and service... shall be made in an impartial manner, under such rules and regulations as the President may prescribe, from the persons who are liable for such training and service and who at the time of selection are registered and classified, but not deferred or exempted.

Id. app. $\S 455(\mathrm{a})(1)$. Under current regulations, draftees would be selected at random within age groups, beginning each year with those who will turn 20 that year. 32 C.F.R. $\S 1642.1-4$ (1988). 
obligation, such as military service, has changed over time, as has the allocation of the tax burden. ${ }^{368}$ Some readers may be troubled by the notion that the list of civic obligations could be expanded. Thus, it may be useful to consider how far the concept of civic obligations could extend.

In some circumstances, the civic obligation theory seems implausible. For example, if the government forced $A$ to give up lier land without compensation so that the government could build a post office on it, a court would be very unlikely to accept the theory that this was $A$ 's "civic obligation." Giving up an interest in land does not correspond with our currently accepted notions of civic obligations. ${ }^{369}$ Even more significant is the fact that $A$ lias been singled out to bear this burden. If the obligation stems from $A$ 's role as a member of the political community, why should $A$ alone bear this burden?

Now let us consider a hypothetical in which the claimant has not been singled out to bear the burden. Assume that all of the residents of a small town hive on Mam Street, and the town council has decided that the street should be widened. If the town council were to conclude that it was each resident's civic obligation to give up an easement (without compensation) to permit the widening of Main Street, would this effect a taking? Many readers presumably would say that this must be a taking, either because the residents are being required to give up their rights to land, or because there is a "physical invasion" of their land. Given our well-defined traditions regarding the range of civic obligations, it is diffcult to imagine a city council viewing the giving up of an easement as a civic obligation. Yet under my theory it is difficult to find a basis for saying that this could never be regarded as a civic obligation. ${ }^{370}$ Thus,

368. Significant changes in eligibility and liability for military training and service have occurred in areas such as age requirements and treatınent of resident aliens. On changes in age requirements, sec supra note 364 . On changes in treatment of aliens, compare, e.g., Military Selective Service Act, 50 U.S.C. app. § 453(a) (1982) ("any alien lawfully admitted to the United States as a nonimmigrant" not subject to draft registration) with Selective Training and Service Act of 1940, ch. 720, § 2, 54 Stat. 885, 885 (1940) (expired 1947) (male aliens "residing in the United States" required to submit to registration). Mandatory draft registration itself has not been a permanent fixture in American law and culture. See J. Nowak, R. Rotunda \& J. Young, Constiturional Law 1065 (2d ed. 1983) (stating that prior to the Civil War, the conscription of men into the armed service was a matter regulated by state law, and that it was customary during that time to allow a person to avoid service by payment of a fee).

369. More specifically, giving up an interest in land without receiving just compensation is not generally regarded as a civic obligation today. One could say that it is regarded as $A$ 's civic obligation to give up the land for a public use if just compensation is paid.

370. Similarly, suppose a city council concluded that it was the duty of local residents to provide food and clothing for the poorest residents of the city. Instead of imposing a monetary tax to raise funds for this purpose, however, the city council enacted a law requiring each resident with an income above a ccrtain level to provide a certain amount of food and clothing to support the program. Would this constitute a taking? Again, this is not a traditionally aceepted civic obligation, yet it is difficult to find a theoretical basis for finding a taking. In what relevant respect would this 
the moral justification principle leaves open the possibility of an expanding range of civic obligations that would not be considered compensable takings.

Before leaving the category of civic obligations, it may be useful to discuss taxes in more detail, for not every case involving a tax will fall withm the category of civic obligations. In soine cases, a law that is labelled a "tax" does not effect a taking because the government is asking $A$ to pay for the harm she is causing to others. These laws are designed to prevent "wrongdoing" in the usual sense. That is, the moral judgment does not depend upon viewing $A$ as a member of the political coinmumity. ${ }^{371}$

In City of Pittsburgh v. Alco Parking Corp., ${ }^{372}$ for example, the owners of private parking garages complained that a city ordinance that imposed a twenty percent tax on their gross receipts effected a taking. They claimed that a majority of them were operating their businesses at a loss because of the tax, and that their competitors-the publicly owned parking garages-were operating at an unfair advantage because they were exeinpt from taxation. ${ }^{373}$ The Court found no taking, explaining that the city's rationale for inposing this "special tax" was that "those providing and utilizing nonresidential parking facilities should pay more taxes to compensate the city for the probleins incident to offstreet parking,"374 such as traffic congestion downtown. As the Court saw it, the tax was designed to give those who custoinarily would drive downtown the choice of eitler paying mcreased rates for parking or using other forms of transportation.

The tax in Alco Parking was much like a development exaction. A local government imight say to a developer, "If you want to build a residential subdivision, you must either provide a park or pay a fee to be used for parks." 375 Here the City of Pittsburgh was saying, "If you want to run a parking garage downtown, you inust pay for the traffic congestion that the parkers will cause." Argnably, the city viewed it as wrong to run a parking garage without paying for the problems created by

law differ from many taxes? The lawmakers have concluded that there is a civic obligation to make these contributions, and the burden of the law is broadly distributed.

371. Rather, these are cases in which $A$ 's failure to pay for the harm that $A$ caused could reasonably be regarded as wrongful.

372. 417 U.S. 369 (1974).

373. The Court stated that the Parking Authority was "a public agency enjoying tax exemption (although not necessarily from this tax)," since the Pennsylvania courts had not yet resolved whether the publicly owned parking garages were exempt from this tax. Id. at 372 .

374. Id. at 378-79.

375. Development exactions often provide that a fee may be paid in lieu of a contribution of land or other tangible resources. See D. Mandelker \& R. Cunningham, PlanNing and Control of Land Development 513 (2d. ed. 1985). 
doing so. ${ }^{376}$ This is quite different from an incoune tax, where the government inakes no claim that the taxpayer has created a problem or has caused harm to others by earning income. Rather, the government imposes the tax because it needs revenue to fund governmental programs.

Taxes designed to prevent the taxpayer from engaging in certain conduct also warrant separate discussion. In a number of cases, the taxpayer has claimed that the government enacted a tax that was so high that it effectively prohibited the conduct being taxed. The Court has held open the possibility that such a tax could effect a taking. For example, in Alco Parking, responding to the claimants' contention that the challenged tax was an unfair ineans of driving them out of their businesses, the Court acknowledged that "[a] taxing statute [inay be] 'so arbitrary as to coinpel the conclusion that it does not involve an exertion of the taxing power, but constitutes, in substance and effect, the direct exertion of a different and forbidden power, as, for example, the confiscation of property." "377

Although a "prohibitory tax" is rarely imposed, let us consider for a moinent how such a tax would be analyzed, using the principles offered in this Article. If the governinent were to enact a law taxing certain economically valuable conduct, and if the purpose and effect of that law were to prevent people from engaging in such conduct, then the governinent would intentionally be depriving those people of their econoincally valuable freedo1n. According to the moral justification principle, unless the governinent had a inoral justification for its action, a taking would occur.

The lawinakers imight impose such a tax based on a reasonable betief that the public would consider the economically valuable conduct to be wrongful. In the Child Labor Tax Case, ${ }^{378}$ for example, the Court found that a high tax levied on einployers of children was clearly designed to stop the einployinent of children under a certain age. ${ }^{379}$ If the tax had been challenged as a taking, ${ }^{380}$ the claim should have been rejected, for the government had clearly inade a judginent that the conduct it was

376. Similarly, in the Head Money Cases, 112 U.S. 580 (1884), the Court described a law requiring shipowners to pay inoney into a fund in order "to mitigate the evils inherent in the business of bringing foreiguers to this country" as an exercise of the government's power to regulate immigration, not an exercise of its power to tax. Id. at 595.

377. 417 U.S. at 375 (quoting A. Magnano Co. v. Hamilton, 292 U.S. 40, 44 (1934)).

378. 259 U.S. 20 (1922).

379. The amount of the tax was $10 \%$ of the employer's profits for the year. The Court remarked:

[T]his Court has gone far to sustain taxing acts as such, even though there has been ground for suspecting from the weight of the tax it was intended to destroy its subject.... [But this tax law's] prohibitory and regulatory effect and purpose are palpable. All others can see and understand this. How can we properly shut our minds to it?

Id. at 37.

380. No takings claim was raised in the Child Labor Tax Case. The issue before the Court was 
trying to stop was wrongful. ${ }^{381}$

Contrast this example with a case in which no judgment of wrongdomg was made. Suppose the government imposed an extremely high tax on the sale of a product solely to aid those who marketed a competing product. Arguably, this was the case in A. Magnano Co. v. Hamilton, ${ }^{382}$ in which the State of Washington imposed a high tax on the sale of butter substitutes in the state. While the Court acknowledged that this tax might well destroy the claimant's intrastate business, it was unwilling to conclude that the tax was designed to prohibit the sale of butter substitutes. ${ }^{383}$ However, if one assuines, as the claimant alleged in Magnano, that the tax was designed to stop the sale of butter substitutes and that the lawmakers' sole purpose was to aid the dairy industry, ${ }^{384}$ then the tax effected a taking under the principles offered in this Article. ${ }^{385}$ This follows because the government imtentionally deprived private parties of their freedom to act in an economically valuable manner without having a inoral justification for doing so.

\section{K. Re-examining the Cases in Light of the Moral Justification Principle}

\section{Takings Clause Decisions}

The preceding sections have shown how the moral justification prin-

whether Congress was regulating in an area that had been reserved to the states by the tenth amendment.

381. In fact, the Court commented: "Although Congress does not invalidate the contract of employment or expressly declare that the employment within the mentioned ages is illegal, it does exhibit its intent practically to achieve the latter result by adopting the criteria of wrongdoing and imposing its principal consequence on those who transgress its standard." Child Labor Tax Case, 259 U.S. at 38.

382. 292 U.S. 40 (1934).

383. The Court concluded that this was not a case where "[the law's] necessary interpretation and effect be such as plainly to deinonstrate that the forin of taxation was adopted as a mere disguise, under which there was exercised, in reality, another and different power . . . as for example, the confiscation of property." Id. at 44-45. The Court distinguished the Child Labor Tax Case, 259 U.S. 20 (1922), stating that "although the [Child Labor] exaction was called a tax, it was, in fact, not a tax but a penalty." Magnano, 292 U.S. at 46.

384. That is, assume that the evidence showed that the lawmakers did not make a judginent that butter substitutes were harmful to the public or that it would be wrong to sell them for some other rcason.

Geoff Miller asserts in Public Choice at the Dawn of the Special Interest State: The Story of Butter and Margarine, 77 CALIF. L. REV. 83 (1989):

[F]or over three quarters of a century, between the 1870 s and the 1950 s, inargarine was the victim of a sustained and concerted pattern of discrimination by the national governinent and almost every state in the union. The antimargarine laws that resulted werc the Id. at 83 .

construct of a powerful, highly sophisticated special interest: the American dairy industry.

385. Indeed, if the tax simply reflected a "naked preference" for the dairy industry, rather than a judgment that this law would promote the common good, the taking would not even satisfy the public use test. See supra notes 161-62. 
ciple accounts for a large number of the Court's takings decisions. ${ }^{386}$ This section examines some of the cases that appear to be at odds with the moral justification principle. In several of these cases, the Court stated more or less explicitly that whether a taking occurred did not depend on whether the government had a moral justification for requiring the claimant to give up her property. The clearest examples of this are Penn Central Transportation Co. v. New York City, ${ }^{387}$ Miller v. Schoene, ${ }^{388}$ and Calero-Toledo v. Pearson Yacht Leasing Co. ${ }^{389}$ As shown below, although some of the language in these opimions is inconsistent with the principles articulated in this Article, the result ultimately reached by the Court in each case could be explamed using the inoral justification principle.

In Penn Central, the Court at one point rejected the notion that whether a taking occurs depends upon whether the government is prohibiting a "noxious" or otherwise blameworthy land use. Although the Court had stated in a number of earier cases that no taking occurs when the government prohibits a noxious use or a nuisance, the Penn Central Court, relying on Joseph Sax's first article on the takings clause, ${ }^{390}$ stated that this was not an adequate explanation of those cases. Quoting Sax, the Court described the conduct at issue in a number of those cases as "perfectly lawful" and "involv[ing] no "blameworthiness [or] moral wrongdoing." ",391 Yet in the very next paragraph, the Court asserted that the claimants' proposed alteration of Grand Central Terminal could be viewed as harmful conduct:

Nor ... can it be asserted that the destruction or fundamental alteration of a historic landmark is not harmful. The suggestion that the beneficial quality of appellants' proposed construction is established by the fact that the construction would have been consistent with applicable zoning laws ignores the development in sensibilities and ideals reffected in landinark legislation like New York City's. ${ }^{392}$

Since the Court had previously been discussing whether the noxious use cases involved "blameworthiness [or] wrongdoing," the Court evidently was saying that the conduct at issue could be viewed as wrongful, not just harmful.

386. I use the term "moral justification principle" to identify the principle that even if the government intentionally deprives $A$ of her property, no compensable taking occurs so long as the governmental decisionmakers are seeking to prevent or punish behavior by $A$ that they reasonably believe the public would consider wrongful.

387. 438 U.S. 104 (1978).

388. 276 U.S. 272 (1928).

389. 416 U.S. 663 (1974).

390. Sax I, supra note 147. See the discussion of Takings and the Police Power at supra text accompanying notes 167-74.

391. Penn Central, 438 U.S. at 134 n.30 (quoting Sax I, supra note 147, at 50).

392. Id. 
As discussed above, some people probably would consider it wrong to alter dramatically such an historically significant buildimg as Grand Central Terminal, while others would disagree. ${ }^{393}$ This lack of consensus makes Penn Central a difficult case, and arguably it was wrongly decided under the principles articulated in this Article. However, given the great deference accorded the governmental decisionmaker's judgment under the moral justification principle, the result in Penn Central could be explained by saying that the Landmarks Preservation Commission could plausibly have concluded that the public would consider it wrong to build the proposed office building on top of Grand Central Terminal. ${ }^{394}$

Miller v. Schoene ${ }^{395}$ is another case in which the Court suggested that whether a taking occurred did not depend upon whether the government had a moral justification for depriving the claimant of her property. To the contrary, the Court strongly suggested at one point in the opinion that the takings issue before it turned on whether the deprivation of property would promote the common good. After stating that the state had to make a choice between saving the apple trees or saving the cedar trees, the Court asserted that "the state does not exceed its constitutional powers by deciding upon the destruction of one class of property in order to save another which, in the judgment of the legislature, is of greater value to the public."396 This statement is inconsistent with the moral justification principle. If the state legislature made a judgment that it would benefit the public to destroy the cedar trees, the taking was for a public use. But if the cedar trees were destroyed solely to promote the common good, rather than because the lawmakers reasonably believed it would be wrong of the owners not to destroy thein, just compensation should have been paid..$^{397}$

393. See supra text accompanying notes 186-88 \& 245-47.

394. This assumes that the legislative body authorized the Landmarks Preservation Commission to make a judgment of wrongdoing. However, some of the legislative history quoted by the Court in Penn Central suggests that the lawmakers were only concerned about the desirability of preserving landmarks. See supra note 300. For that reason, Penn Central may have been wrongly decided under the moral justification principle.

395. 276 U.S. 272 (1928).

396. Id. at 279.

397. Although Miller $\boldsymbol{v}$. Schoene is considered a difficult case by many, under the takings jurisprudence proposed by Sax in Takings and the Police Power, the case presents no difficulties. Sax argued that whenever the government is acting in its "arbitral" capacity, resolving disputes between private parties, no taking occurs. Sax was not concerned about whether the dispute was resolved on the basis of a judgment of wrongdoing. Thus, he argued that since Miller $v$. Schoene involved a dispute between the cedar tree owners and the apple tree owners, and the challenged law resolved that dispute, there was no taking. Sax I, supra note 147, at 69.

In Takings, Private Property and Public Rights, supra note 169, Sax somewhat altered his theory of the takings clause. He still contended, however, that Miller v. Schoene was a clearcut case. Sax argued that whenever two land uses conflict, either use may be prohibited without compensation, so long as the government is seeking to maximize the value of the resource base. Applying this principle, Sax viewed Miller v. Schoene as correctly decided. Id. at 165. 
The state legislature, however, had declared the infected cedars to be a "public nuisance" 398 and a "menace to the health"399 of the apple trees. This legislative language suggests a judgment of blame or wrongdoing. ${ }^{400}$ Moreover, the Court analogized the case to noxious use cases sucl 1 as Hadacheck v. Sebastian ${ }^{401}$ and Mugler v. Kansas. ${ }^{402}$ Although it may be a borderline case, Miller v. Schoene could have been decided on the ground that no taking occurred because the lawmakers were prohibiting conduct that they reasonably believed the public would consider wrongful. Indeed, in Keystone Bituminous Coal Association v. DeBenedictis, ${ }^{403}$ the Court rehed on Miller v. Schoene to support its assertion that in previous cases the Court had not found a taking when the government was simply prohibiting a noxious use. ${ }^{404}$

Finally, in Calero-Toledo v. Pearson Yacht Leasing Co., ${ }^{405}$ the Court imitially suggested that the takings issue does not depend on whether the government has a inoral justification for depriving the claimant of her property. However, the Court retreated from that position at the close of its opimion. In Calero-Toledo, the lessor of a yacht claimed that a taking occurred when the Puerto Rican government seized his yacht and declared it forfeited to the government because the lessees had marijuana on board. The lessor asserted that he had neither been involved in nor aware of the lessees' wrongful use of the yaclit. The lessor relied on United States v. United States Coin \& Currency, ${ }^{406}$ in which the Court had remarked that although forfeiture actions traditionally have proceeded upon the fiction that imanimate objects themselves can be guilty of wrongdoing, a forfeiture statute that required forfeiture of the property of an innocent owner would raise serious questions under the takings clause. ${ }^{407}$

398. Miller v. Schoene, 276 U.S. at 277.

399. Id. at 278.

400. The statement that the cedar trees were a "menace to the health" of the apple trees suggests that the diseased cedars were viewed as the cause of the harm. Although one can argue that this is not a rational basis for attributing fault, many people would blame the owner of an animal or other thing that is diseased if he took no action to prevent that disease from harming others.

401. 239 U.S. 394 (1915).

402. 123 U.S. 623 (1887).

403. 480 U.S. 470 (1987).

404. Id. at 490 .

405. 416 U.S. 663 (1974).

406. 401 U.S. 715 (1971).

407. The Court had stated:

Traditionally, forfeiture actions have proceeded upon the fiction that inanimate objects themselves can be guilty of wrongdoing. Simply put, the theory has been that if the object is "guilty," it should be held forfeit. ... .

It would appear then that history does support the Government's contention regarding the operation of this forfeiture statute, as do several decisions rendered by the courts of appeals. But before the Government's attempt to distinguish the Boyd case could even begin to convince, we would first have to be satisfied that a forfeiture statute, with such a broad sweep, did not raise serious constitutional questions under that portion of the 
The Court found no taking in Calero-Toledo, stating that prior decisions estabhished that "the property owner's innocence has no constitutional significance for purposes of forfeiture."408 This statement appears to be directly contrary to the moral justification principle. However, the Court evidently was using the term "innocence" to inean lack of direct involvement in or awareness of the criminal enterprise. At the close of the opinion, the Court strongly suggested that a taking would occur if "[the owner] proved not only that he was uninvolved in and unaware of the wrongful activity, but also that he had done all that reasonably could be expected to prevent the proscribed use of his property."409 According to the majority, the lessor did not even allege that he had done all that reasonably could have been expected to prevent the unlawful use of the yacht. ${ }^{410}$ The dissent, however, argued that the case should be remanded for findings "as to the ninocence of the lessor of the yacht-whether the illegal use was of such inagnitude or notoriety that the owner cannot be found faultless in remaining ignorant of its occurrence."411

Thus, in Calero-Toledo the Court was ultimately dissatisfied with the notion that forfeiture may be justified by relying upon the fiction that the thing itself is the wrongdoer. At the close of the opimion, the Court in effect said that the case would be different if the claimant were not at fault - that is, if there were no basis for blaming him for the illegal use of the yacht. Although much of the language in Calero-Toledo appears to be inconsistent with the moral justification principle, the Court's parting words return to the notion that the government's inoral justification for depriving the clannant of his property is critical in takings cases.

Of course, not every takings decision can be reconciled with the principles offered in this Article. Two cases that are particularly difficult to explain using the moral justification principle are Pennsylvania Coal

Fifth Amendment which commands that no person shall be "deprived of . . . property, without due process of law; nor shall private property be taken for public use, without just compensation." Even Blackstone, who is not known as a biting critic of the English legal tradition, condemned the seizure of the property of the innocent as based upon a "superstition" inherited from the "blind days" of feudalism. And this Court in the past has recognized the difficulty of reconciling the broad scope of traditional forfeiture doctrine with the requirements of the Fifth Amendment.

Id. at 719-21 (citations omitted) (referring to Boyd v. United States, 116 U.S. 616 (1886)).

408. 416 U.S. at 669.

409. Id. at 689. The Court stated that "in that circumstance, it would be difficult to conclude that forfeiture served legitimate purposes and was not unduly oppressive." Id. at 689-90.

410. Id. at 690 .

411. Id. at 694 (Douglas, J., dissenting in part).

One issue that might have been raised in Calero-Toledo is whether the punishment was grossly disproportionate to any wrong the lessor of the yacht may have committed. Justice Douglas commented that "so far as we know only one marihuana cigarette was found on the yacht." Id. at 693. For a discussion of disproportionate pumishment, see infra note 486 . 
Co. v. Mahon ${ }^{412}$ and Loretto v. Teleprompter Manhattan CATV Corp..$^{413}$ In both cases, the Court found takings even though the lawmakers had plausible moral justifications for depriving the claimants of their property. But as discussed below, the Court came very close to overruling Pennsylvania Coal in Keystone Bituminous Coal Association v. DeBenedictis, ${ }^{414}$ and Loretto was simply wrongly decided. ${ }^{415}$

In Pennsylvania Coal, ${ }^{416}$ the Court held that the Kohler Act, which prohibited mining that caused subsidence under dwellimgs and various public structures and facilities, effected a taking. Justice Holmes, writimg for the majority, emphasized that the mining companies had purchased the right to inine in a manner that would cause subsidence, and that the Kohler Act greatly diminished the value of the compamies' mining rights. Justice Brandeis, dissenting, argued that this law merely prohibited conduct that the lawmakers could reasonably consider to be "noxious" or a "public nuisance," and thus no compensation was due. ${ }^{417}$ He asserted that "[i]f public safety is imperiled, surely neither grant, nor contract, can prevail against the exercise of the police power." ${ }^{.18}$

Viewed within the framework offered in this Article, Pennsylvania Coal appears to have been wrongly decided. At least, if the Kohler Act were enacted today, it would seem quite plausible that the lawmakers reasonably believed the public would consider it wrong to mine in a manner that would cause subsidence under dwellings and public structures, even if one liad purchased the right to do so. Perhaps such a judgment of wrongdoing seemed less plausible back in 1922, when Pennsylvania Coal was decided.

It is not surprising that the Supreme Court caine very close to overruling Pennsylvania Coal in Keystone Bituminous Coal Association v. DeBenedictis, ${ }^{419}$ where it rejected a takings challenge to a very similar statute. ${ }^{420}$ One reason the Court found no taking in Keystone was that it considered mining that causes subsidence under dwellings and public

412. 260 U.S. 393 (1922).

413. 458 U.S. 419 (1982).

414. 480 U.S. 470 (1987).

415. That is, the decision in Loretto was inconsistent with the pattern established by the Court's other takings decisions.

416. 260 U.S. 393 (1922).

417. Id. at 417 (Brandeis, J., dissenting).

418. Id. at 420. Justice Brandeis further argued: "I suppose no one would contend that by selling his interest above one hundred feet froin the surface he could prevent the State from liniting, by the police power, the height of structures in a city. And why should a sale of underground rights bar the State's power?" Id. at 419.

419. 480 U.S. 470 (1987).

420. The Subsidence Act, challenged in Keystone, prohibited mining that would cause subsidence damage to certain structures, such as public buildings and dwellings used for human habitation. Id. at 476 . 
structures to be "akin to a public nuisance."421 The Court distinguished Pennsylvania Coal by asserting that the decision evidently rested on a conclusion by the Court that the Kohler Act had been enacted to serve purely private interests, but that "circumstances may so change in time ... as to clothe with such a [public] interest what at other times ... would be a matter of purely private concern." "422 This is not a very convincing basis for distinguishing Pennsylvania Coal, for it is not at all clear that the decision in that case rested on the conclusion that the Kohler Act furthered purely private interests. If that were true, however, the holding in Pennsylvania Coal would be consistent with the principles offered here. A taking would have occurred, for the government would have intentionally deprived private parties of their property without having any moral justification for doing so. ${ }^{423}$

It is more difficult to harmonize the Court's holding in Loretto v. Teleprompter Manhattan CATV Corp. ${ }^{424}$ with the inoral justification principle. In Loretto, the Court found that a law that required a landlord to permit the installation of cable TV facilities to serve her own tenants effected a taking, because the government was authorizing the "permanent physical occupation" of a small area on the roof of the building. As discussed above, the New York legislature had a plausible moral justification for requiring landlords to permit such "noncrossover" installations. ${ }^{425}$ Responding to cases in which landlords had made it very difficult for tenants to obtain cable TV service, the lawmakers had concluded that "a landlord should not be able to preclude a tenant from obtaining CATV service, ... . any more than he could preclude a tenant from receiving mail or telegrains directed to him." ${ }^{426}$ Thus, with respect to such installations, Loretto was wrongly decided. ${ }^{427}$ Indeed, as the dis-

421. Id. at 488 .

Epstein has argued that Keystone was wrongly decided because the inining companies had acquired the right to mine in a manner that would cause subsidence. In Epstein's view "[t]here ean be no claim that the police power governs where the injured party has assumed the risk in question." Epstein, Takings: Descent and Resurrection, 1987 SUP. CT. REV. 1, 21. Given Epstein's rigidly confined view of wrongdoing, he found it difficult to understand the Court's view of the case. As the Court expressed it, the coal coinpanies' position was that, "because they contracted with some previous owners of property generations ago, they have a constitutionally protected legal right to conduct their mining operations in a way that would make a shambles of all those buildings and ceineteries." Keystone, 480 U.S. at 504-05.

422. Id. at 488 (quoting Block v. Hirsh, 256 U.S. 135, 155 (1921)).

423. In fact, if the government acted to serve purely private ends, the government's action did not even satisfy the public use test, and thus enforceinent of Kohler Act was properly enjoined.

424. 458 U.S. 419 (1982).

425. See supra text accoinpanying notes $224-25$.

426. Loretto, 458 U.S. at 445 n.3 (Blackmun, J., dissenting).

427. As discussed at supra text accompanying note 227 , Loretto arguably was correctly decided with respect to "crossover installations," since the lawinakers may have required landlords to permit the installation of cable facilities to serve those living in other buildings smiply because this would promote tlie coinunon good. 
sent pointed out, if one took the Loretto holding seriously, a taking would occur if the government required a landlord to permit the installation of locks or fire escapes. ${ }^{428}$ Yet it seems highly unlikely that the Court would find a taking in either case.

Some of the wartime cases may also be difficult to explain using the principles offered in this Article. Societal judgments of wrongdoing are hard enough to identify in time of peace; they are far more difficult to assess in time of war. ${ }^{429}$ We inay agree that the government must pay compensation if it seizes $A$ 's ships to supply the navy, ${ }^{430}$ and that the government need not pay compensation if it seizes a tangible resource that $A$ is deliberately using to aid the enemy. ${ }^{431}$ Yet, as United States $v$. Caltex, Inc. ${ }^{432}$ demonstrates, many wartime takings cases are more difficult to resolve. ${ }^{433}$

Under the principles offered in this Article, one would expect the Court frequently to deny claims for compensation in wartime cases, where it is often difficult to say that a judgment of wrongdoing is implausible. Indeed, the Court has been inclined to deny compensation in wartime cases, ${ }^{434}$ yet it has not always explained its decisions in terins that square with the inoral justification principle. Sometimes the Court has stated or suggested that "necessity" justifies the demal of compensation

428. 458 U.S. at $449 \&$ n.7 (Blackmun, J., dissenting).

429. In wartime, it is particularly difficult to judge whether the public would consider it "wrong" of $A$ not to give up her property without receiving coinpensation. A heightened sense of civic obligation during wartime and the sense that everyone is suffering some hardships because of the war (and thus $A$ is not being unfairly singled out) are two factors that would broaden the range of cases in which it might be considered wrong of $A$ not to give up her property without receiving compensation.

430. See Russian Volunteer Fleet v. United States, 282 U.S. 481 (1931) (the takings clause required the payment of compensation when the U.S. Government requisitioned the claimant's contracts for the construction of two vessels-and the vessels themselves-for use by the government during World War I). Sinilarly, in United States v. Caltex, Inc., 344 U.S. 149 (1952), the Court approved of two prior cases in which the Army had impressed the claimants' equipment for use by the Army, and compensation was required by the Court. Id. at 153.

431. See Young v. United States, 97 U.S. 39 (1877) (upholding the government's power to deny compensatiou to a blockade ruuner whose contraband cotton had been seized by the U.S. Government during the Civil War, stating that the claimant had been "im league with the Confederate government," $i d$. at 65 , and that "[i]f he breaks a blockade or engages in contraband trade, he subjects himself to the chances of the capture and confiscation of his offending property," id. at 63).

432. 344 U.S. 149 (1952).

433. See supra text accompanying notes $182-85$.

434. See, e.g., United States v. Central Eureka Mining Co., 357 U.S. 155 (1958) (concluding that the War Production Board had "made a rcasoned decision that ... the Nation's need was such that the unrestricted use of nining equipment and manpower in gold mines was so wasteful of wartinie resources that it mnst be temporarily suspended," $i d$. at 168 , and cominenting that "[i]n the context of war, we have been reluctant to find that degree of regulation which ... requires compensation to be paid for resulting losses of income," id.); Caltex, 344 U.S. 149 (discussed at supra text accompanying notes 182-85). 
for property taken or destroyed during time of war. ${ }^{435}$ But although the public use test is satisfied if it is necessary to take or destroy $A$ 's property in order to promote the common good, that does not explain why it is fair to deprive $A$ of her property without paying compensation. Moreover, the "necessity" explanation does not account for some of the generally accepted propositions as to when compensation is due in wartime cases. For example, the seizure of supplies or vessels from $A$ may be "necessary" to support the war effort, yet it is generally accepted that the government inust compensate $A$ in such cases. ${ }^{436}$

The inoral justification principle has great explanatory power. Yet there undoubtedly are Supreme Court takings decisions that cannot easily be explained using this principle. Probably no single theory would account for the result in every Supreme Court takings decision. The virtue of the moral justification principle is that it seeins to account for the results in a large percentage of the Court's takings cases, and it explains why some cases are hard and otliers are easy. ${ }^{437}$ Thus, it seems to capture the essence of the takings inquiry.

\section{Substantive Due Process Cases Involving the Government's Broad Power to Regulate to Promote the Common Good}

Some readers may see the inoral justification principle as conflicting with the notion expressed in many substantive due process cases of the post-Lochner era that, when it comes to economic inatters, the govern-

435. See, e.g., United States v. Pacific R.R., 120 U.S. 227, 234 (1887) (stating in dictum that when military necessity requires the destruction of private property, "the safety of the state ... overrides all considerations of private loss"). Indeed, in Caltex the Court quoted this statement with approval. 344 U.S. at 154.

436. See supra note 430. In United States v. Russell, 80 U.S. (13 Wall.) 623 (1871), where the U.S. Government lad used the claimant's steamers during a military emergency, the Court stated: Sucl a taking of private property by the government, when the emergency of the public service in time of war or impending public danger is too urgent to admit of delay, is everywhere regarded as justified ... . and it is equally clear that the taking of such property under sucli circumstances creates an obligation on the part of the goverument to reimburse the owner to the full value of the service. Private rights, under such extreme and imperious circumstances, must give way for the time to the public good, but the government must make full restitution for the sacrifice.

Id. at 629 .

The United Nations' International Law Commission has recognized that the existence of a state of "necessity" does not resolve whether compensation is due. Report of the International Law Commission to the General Assembly on the work of its thirty-second session, 35 U.N. GAOR Supp. (No. 10) at 131-32, U.N. Doc. A/35/10 (1980), reprinted in [1980] 2 Y.B. INT'L L. COMM'N 61, U.N. Doc. A/CN.4/SER.A/1980/Add.1 (Part 2) (even if a country's action is not regarded as wrongful because it was occasioned by a "state of necessity," compensation may nevertheless be due for damage caused by the act).

437. Of course, the takings issue is rarely litigated in the easiest cases, since those cases by definition are ones in whicl it is generally accepted that no taking has occurred (or that a taking has occurred). The takings cases that are litigated are ones presenting more difficult issues. Moreover, the cases that reach the U.S. Supreme Court are likely to be the most difficult of all, since the Court tries to resolve issues that have produced conficting decisions by the lower courts. 
ment has broad power to regulate to promote the common good. In the well-known case of Nebbia v. New York, ${ }^{438}$ for example, the Court stated: "So far as the requirement of due process is concerned, and in the absence of other constitutional restriction, a state is free to adopt whatever economic policy may reasonably be deemed to promote public welfare, and to enforce that policy by legislation adapted to its purpose." 439

If tlie Court were stating in these substantive due process cases that the constitutionality of economic regulation turns solely on whether the government is acting to promote the common good, that statement would conflict with tlie moral justification principle. However, the Court appears to be stating simply tliat substantive due process requires the government to be acting to promote tlie common good, and that the Court will defer greatly to the legislature's judgment on what promotes the common good. ${ }^{40}$ Thus, economic legislation that satisfies substantive due process requirements could still effect a taking. Indeed, that proposition is self-evident, since the Court has equated the public use requirement of the takings clause witl the minimum rationality standard of substantive due process, ${ }^{441}$ and the government plainly can satisfy tlie public use requirement and still effect a compensable taking. ${ }^{442}$

Under tlie moral justification principle, economic regulation that satisfied substantive due process would seldom effect a compensable taking. In most cases, no taking would occur because tlie legislature not only could reasonably believe thiat the cliallenged law would promote the common good, but also could reasonably believe that tlie cliallenged law would prevent or pumisl "wrongdoing," as that tern is used im this Article. In Nebbia, for example, the Court concluded that the challenged law did not violate substantive due process, simce tlie legislature had reasonably determined that setting mimimum prices for milk would promote tlie common good. ${ }^{443}$ If a takings claim liad been raised, ${ }^{444}$ tlie Court also could have found that the lawmakers reasonably believed they were

438. 291 U.S. 502 (1934).

439. Id. at 537 .

440. Indeed, the Court has often explicitly recognized (as it did in the passage from Nebbia, supra text accompanying note 439), that economic legislation that meets the requirements of substantive due process may run afoul of other constitutional restrictions.

441. See supra note 32.

442. In Ruckelshaus v. Monsanto Co., 467 U.S. 986 (1984), for example, the Court held that the challenged law satisfied the public use test but effected a compensable "taking" with respect to certain data. Similarly, in Pennell v. City of San Jose, 485 U.S. 1 (1988), Justice Scalia concluded that the challenged rent control ordinance satisfied the requirements of substantive due process but effected a taking. Id. at 15 (Scalia, J., concurring in part and dissenting in part). The majority did not reach the takings issue in Pennell.

443. Nebbia, 291 U.S. at 537-39.

444. It would have been somewhat difficult for the claimant to establish that the challenged regulation caused him economic harm, since it set a minimum price at which milk could be sold. 
preventing wrongdoing in regulating the price of milk. The legislature had found that minimum price regulation was needed to coinbat "unhealthful, unfair, unjust, destructive, demoralizing and uneconomic trade practices" in the milk industry, practices that posed an inmediate danger to the public health and welfare. ${ }^{445}$ The Court spoke of the legislature's effort to prevent "destructive price-cutting," "unfair trade practices," and "ruthless competition." 446 It also stated that "[t]he Constitution does not secure to anyone liberty to conduct his business in such fashion as to inflict injury upon the public at large, or upon any substantial group of the people." 447 Not only is this language reminiscent of the "noxious use" cases, ${ }^{448}$ but the Court actually cited Mugler v. Kansas, ${ }^{449}$ Hadacheck v. Sebastian, ${ }^{450}$ and Village of Euclid v. Ambler Realty Co. ${ }^{451}$ in upliolding the cliallenged law. ${ }^{452}$ The Court, therefore, evidently viewed the legislature as having made a reasonable judgment that "destructive price cutting" in the milk industry wrongfully harmed otliers.

West Coast Hotel Co. v. Parrish ${ }^{453}$ is another example of a substantive due process case in which the Court decided that the lawinakers reasonably believed they were promoting the cominon good, but in which it also could liave concluded that the lawmakers reasonably believed they were preventing wrongdoing. The law cliallenged in West Coast Hotel fixed minimum wages for women. The Court described this as regulation designed to protect employees from "unscrupulous and overreaching employers" 454 by "reduc[mg] the evils of the 'sweating systein,' the exploiting of workers at wages so low as to be imsufficient to meet the bare cost of living." 455 The Court portrayed employers who paid less than a "living wage" as wronging not only their employees, but also the public:

445. Nebbia, 291 U.S. at 518 n.2.

446. Id. at 530 .

447. Id. at 538-39.

448. In Mugler v. Kansas, 123 U.S. 623 (1887), for example, the Court relied on the " 'fundamental principle that every one shall so use his own [property] as not to wrong and injure another." "' Id. at 667 (quoting Fertilizing Co. v. Hyde Park, 97 U.S. 659, 667 (1878)).

The "noxious use" cases are discussed in Peterson I, supra note 4, at 1319, 1358-59. See also supra text accompanying notes 390-92 \& 401-04; infra text accompanying notes 503-14.

449. 123 U.S. 623 (1887). For discussion of Mugler, see supra text accompanying notes 156-58 and 252-55, and infra text accompanying notes 503-06 and 521.

450. 239 U.S. 394 (1915). For discussion of Hadacheck, see supra text accompanying notes 21821 , and infra note 522 and accompanying text.

451. 272 U.S. 365 (1926). For discussion of Village of Euclid, see supra text accompanying notes 265-68, and infra text accompanying notes 507-09.

452. Nebbia, 291 U.S. at 526, 528.

453. 300 U.S. 379 (1937).

454. Id. at 398.

455. Id. at 398-99. 
The exploitation of a class of workers who are in an unequal position with respect to bargaining power and are thus relatively defenseless against the demial of a living wage is not only detrimental to their health and well being but casts a direct burden for their support upon the community. ... The community is not bound to provide what is in effect a subsidy for unconscionable einployers. ${ }^{456}$

It is true that a majority of the Court had viewed that moral issue quite differently fourteen years earher when it decided Adkins v. Children's Hospital. ${ }^{457}$ In Adkins, the majority had concluded that the employer had no "peculiar responsibility" for the imdigency of his employees. ${ }^{458}$ But by the time the Court decided West Coast Hotel, it was far more willing to defer to the legislature's judgment, and it was also far less committed to the notion that the government's regulatory power was largely limited to controlling conduct considered wrongful under traditional common law principles. ${ }^{459}$

Under the moral justification principle-as in West Coast Hotelthe reviewing court would give great deference to the legislature's judgment that the public would regard certain conduct as wrongful. ${ }^{460}$ Moreover, the terin "wrongdomg" would not be confined to a narrow category of cases. Therefore, not ouly minimum wage laws, but also many other types of economic regulation would not effect takings under the moral justification principle. ${ }^{461}$

456. Id. at 399.

457. 261 U.S. 525 (1923).

458. Id. at 558. In Adkins, the Court held that a law fixing minimum wages for women violated substantive due process, stating in part:

To the extent that the sum fixed exceeds the fair value of the services rendered, it amounts to a compulsory exaction from the employer for the support of a partially indigent person, for whose condition there rests upon him no peculiar responsibility, and therefore, in effect, arbitrarily shifts to his shoulders a burden which, if it belongs to anybody, belongs to society as a whole.

Id. at 557-58. The Court overruled the Adkins decision in West Coast Hotel, 300 U.S. 379, 400 (1937).

459. Sunstem has commented that the Court in Adkins focused on the fact that "the employer had committed no common law wrong," and that at the time the Court viewed the government's "regulatory power [as] . . largely limited to the redress of harms recognized at common law." Sunstein, Lochner's Legacy, 87 CoLUM. L. REv. 873, 877 (1987).

460. See supra text accompanying notes 175-77.

461. By way of contrast, under Epstein's approach to the takings clause (which is far more reminiscent of the Lochner era), the reviewing court would give much less deference to the legislature's judgment. According to Epstein, the courts should apply "an intermediate standard of review [in takings cases, as] . . . in Lochner." R. EPSTEIN, supra note 28, at 128. Furthermore, Epstein would essentially confine the notion of wrongdoing to "force" or "fraud." As he expressed it, a governmental deprivation of private property would not effect a compensable taking if the government had a "police power justification" for its action. Id. at 110-12. Yet, according to Epstein, "[t] he sole function of the police power is to protect individual liberty and private property against all manifestations of force and fraud." Id. at 112. Judged by Epstein's standards, a great deal of twentieth-century legislation would violate the takings clause. In fact, Epstein asserted that minimum wage legislation effects a taking. Id. at 280 . 
But even if takings would rarely be found under the moral justification principle, some people may still find that principle troubling because it conflicts with their behef that legislatures have the power to enact any economic regulation that the lawmakers beheve will promote the common good. Perhaps a substantial number of people do share that assumption. Yet how can it be squared with the takings clause? The express language of the takings clause makes it clear that a taking can occur even if the government's action is for a "public use." Moreover, the Court has plainly stated that the mere fact that the government's action promotes the common good does not mean that just compensation is not required. In First English Evangelical Lutheran Church v. County of Los Angeles, ${ }^{462}$ for example, the Court relied on Justice Holmes' famous statement in Pennsylvania Coal Co. v. Mahon ${ }^{463}$ that " 'a strong public desire to inprove the public condition is not enough to warrant achieving the desire by a shorter cut than the constitutional way of paying for the change.'

In order to argue that the constitutionality of at least some forins of economic regulation depends solely on whether the lawmakers reasonably beheved they were seeking to promote the common good, one must contend that such forms of econormic regulation are immune from takings challenges. ${ }^{465}$ It is not at all apparent, however, how one could account for the wide range of cases in which the Court has found that regulatory takings claims were properly raised, ${ }^{466}$ and still make a coherent arguinent that certain types of economic regulation are beyond the scope of the takings clause. ${ }^{467}$ Thus, although the Court inight hold, in soine future case, that a particular type of economic regulation is beyond

462. 482 U.S. 304 (1987).

463. 260 U.S. 393 (1922).

464. First English, 482 U.S. at 321-22 (quoting Pennsylvania Coal, 260 U.S. at 416).

Similarly, in Nollan v. California Coastal Commission, 483 U.S. 825 (1987), the government argued that the public good would be promoted by providing lateral public beach access, and the Court responded that California was "free to ... us[e] its power of eminent domain for this "public purpose,' but if it wants an easement across the Nollans' property, it must pay for it." Id. at 841-42 (citations omitted).

465. Furthermore, even if the challenged law did not violate substantive due process or the takings clause, it might violate other constitutional provisions, such as the first amendment or the commerce clause.

466. See, e.g., Connolly v. Pension Benefit Guar. Corp., 475 U.S. 211 (1986); Ruckelshaus v. Monsanto Co., 467 U.S. 986 (1984); City of Pittsburgh v. Alco Parking Corp., 417 U.S. 369 (1974).

See generally supra text accompanying notes 32-38 (discussing the wide range of cases in which the Court has found that takings claims were properly raised).

467. Sax remarked in a recent article: "[Looking at] cases like Connolly raises the question whether land use cases are different from business regulation cases. I think not, and certainly the Court has never suggested that a different constitutional standard applies to land than is applied to other forms of property." Sax, Property Rights in the U.S. Supreme Court: A Status Report, 7 UCLA J. ENVTL. L. \& PoL'y 139, 151 n.63 (1988). 
the scope of the takings clause, it would be difficult to reconcile such a conclusion with the Court's prior takings decisions.

\section{$\mathrm{V}$}

\section{Where Has THE COURT GONE Wrong?}

Returning now to the Court's articulation of takings doctrine, where has the Court gone wrong? In what respects have the Court's various explanations of when a taking occurs failed to account for the Court's own takings decisions or for certain generally accepted propositions as to when a taking occurs? And do the principles offered in this Article inore fully account for those decisions and those generally accepted propositions?

At this juncture, we could return to the Court's various tests for when a taking occurs-the three-factor Penn Central test, the two-part Agins test, the "no economically viable use" test, and the Loretto per se rule-and we could re-examine each component of each test. But this would be a long process that would take us back to the many uncertainties as to what each test means and when it applies. ${ }^{468}$ It seems inore useful to summarize the major themes that recur throughout the Court's various takings tests and to consider how helpful those themes are in explaining the Court's takings decisions. ${ }^{469}$ This section will compare those themes to the principles offered in this Article and will demonstrate that the principles offered here better account for the Court's takings decisions.

One recurrent theme is that whether a taking occurred depends on what the government did to the claimant, rather than the government's justification for its action. At timies the Court has asked whether the government effectively deprived $A$ of a thing, as when it has asked whether a land-use law deprived $A$ of all economically beneficial use of a parcel of land. At times the Court has asked whether the government inflicted harm of an unusually serious character, such as a pliysical imvasion, on $A .^{470}$ The Court lias also considered the extent to which the government's action had an adverse economic inipact on $A$. In each case, the Court has focused on what the government did to the claimant.

Surely we camiot explain the takings cases by asking whether the

468. See Peterson I, supra note 4, at 1316-34.

469. As shown in Part I of this Article, Peterson I, supra note 4, after examining each of the Court's current takings tests, one is left with a sense of complete chaos. Yet one can begin to organize that chaos by looking for themes that appear repeatedly in the Court's takings decisions.

The three major themes that reappear throughont the Court's takings tests were described in Part I, and a tentative response to each theme was offered. See Peterson I, supra note 4, at 1351-60.

470. Indeed, the Court has concluded that a "permanent physical occupation" is necessarily a taking because of the unusually serious nature of the harm it inflicts. Loretto v. Teleprompter Manhattan CATV Corp., 458 U.S. 419 (1982). 
government effectively deprived $A$ of a thing. After all, the government may deprive $A$ of a tangible resource, yet not commit a taking. This was true in United States v. Caltex, Inc. ${ }^{471}$ and Miller v. Schoene. ${ }^{472}$ It is also true when the government requires $A$ to forfeit a resource that she used in the commission of a crime. Conversely, a taking may occur even if the government has not deprived $A$ of a tangible thing. In Nollan $v$. California Coastal Commission ${ }^{473}$ and United States v. Causby, ${ }^{474}$ for example, a taking occurred even though the claimant was not deprived of the parcel as a whole, and im Ruckelshaus v. Monsanto Co. ${ }^{475}$ and Lynch v. United States, ${ }^{476}$ the taking involved intangible economically valuable rights.

Nor can we explain the Court's takings decisions by focusing on the unusually serious character of the harm suffered by $A$. For one thing, it is difficult to know when the Court will say that the harm is of an unusually serious character, apart from the category of physical invasions. Even if a physical invasion is involved, it is difficult to know whether the Court will consider the physical invasion to be "permanent," and thus a taking per se, or simply "temporary."477 Moreover, in soine cases, such as Caltex, ${ }^{478}$ Miller v. Schoene, ${ }^{479}$ and Calero-Toledo v. Pearson Yacht Leasing Co. ${ }^{480}$ the Court has found no taking even though the government permanently destroyed or confiscated $A$ 's tangible economically valuable resource.

We also cannot explain the cases by focusing on the magnitude of the econonic loss suffered by $A$. In a number of cases in which the Court has found a taking, such as Loretto v. Teleprompter Manhattan CATV Corp. ${ }^{481}$ and Hodel $v$. Irving, ${ }^{482}$ the econonic impact on $A$ has been rather minimal. In other cases, such as Keystone Bituminous Coal

471. 344 U.S. 149 (1952). Caltex is discussed at supra text accompanying notes 182-85.

472. 276 U.S. 272 (1928). Miller v. Schoene is discussed at supra text accompanying notes 18991 and 395-404.

473. 483 U.S. 825 (1987). Nollan is discussed at supra text accompanying notes 57-60, 112-22, 202-06, 222-23, 259-60, and 301-02.

474. 328 U.S. 256 (1946). Causby is discussed at supra text accompanying notes 110-11 and $141-49$.

475. 467 U.S. 986 (1984). Monsanto is discussed at supra text accompanying notes 92-102, 113 22, 282-84, 328-31, and 339-41.

476. 292 U.S. 571 (1934). Lynch is discussed at supra text accompanying notes 69-72, 197-200, and $307-12$.

477. See Peterson I, supra note 4, at 1333-34, 1336-38.

478. 344 U.S. 149 (1952).

479. 276 U.S. 272 (1928).

480. 416 U.S. 663 (1974). Calero-Toledo is discussed at supra text accompanying notes 405-11.

481. 458 U.S. 419 (1982). Loretto is discussed at supra text accompanying notes 224-28 and 424-28.

482. 481 U.S. 704 (1987). Hodel $v$. Irving is discussed at supra text accompanying notes $269-73$ and $285-87$. 
Association v. DeBenedictis, ${ }^{483}$ Caltex, ${ }^{484}$ and Mugler v. Kansas, ${ }^{485}$ the economic loss has been great, yet the Court has found no taking. ${ }^{486}$

It is far easier to account for the Court's takings decisions by asking why the government deprived $A$ of her property, rather than by asking what the government did to $A$. For example, if the government required $A$ to forfeit something she had used in the commission of a crime, no taking would occur despite the fact that she suffered the permanent physical loss of a valuable tangible resource, because the government was punishing wrongdonig by $A .^{487}$ Similarly, if the government prohibited $A$ froin manufacturing alcohohic beverages at a time when such conduct was regarded as wrongful, no taking would occur despite the fact that $A$ suffered serious economic losses, because the government was preventing wrongdoing by $A .^{488}$

Although the issue is not what the government has done to $A$, but why, it is true that a taking is inore likely to occur if a "physical inva-

483. 480 U.S. 470 (1987). Keystone is discussed at supra text accompanying notes $207-09$ and 419-23.

484. 344 U.S. 149 (1952).

485. 123 U.S. 623 (1887). Mugler is discussed at supra text accompanying notes $156-58$ and $252-55$.

486. This is not to say that the magnitude of the burden on $A$ is irrelevant in determining whether a taking occurred. As discussed at supra note 236, the burden on $A$ is one factor that is often considered in determining whether $A$ 's failure to act should be regarded as wrongful. Thus, the reasonableness of a legislative judgment that it would be wrong of $A$ not to do X might depend in part on the magnitude of the burden such a law would impose on $A$. Similarly, the magnitude of the harm $A$ would suffer if prevented from engaging in certain activity unight affect whether it is considered wrong of $A$ not to stop that activity. In many cases, however, the cost to $A$ of stopping a particular activity is great, and yet $A$ 's conduct is regarded as wrongful. See, e.g., Hadacheck v. Sebastian, 239 U.S. 394 (1915) (maintenance of a brickyard in a residential area prohibited); Mugler v. Kansas, 123 U.S. 623 (1887) (production of liquor prohibited).

The magnitude of the burden imposed on $A$ might also be relevant in cases involving the punishment of wrongdoing. The Supreme Court has not considered whether a compensable taking would occur if the government imposed a penalty on $A$ that was disproportionate to the wrong she had conimitted. (The issue of disproportionate punishment is, of course, most often raised under the eighth amendment.) However, under the principles articulated in this Article, if the government required $A$ to forfeit certain cconomically valuable resources because she had committed a crime, and if the penalty were greatly disproportionate to the crime at issue, $A$ might seek to establish that the government's actual purpose was not to punish wrongdoing, but rather to acquire her valuable resources without paying for them. See supra notes 205-10 and accompanying text (discussing actual purpose). Moreover, if the punishment were sufficiently arbitrary, the government's action might violate substantive due process. Since the Court has stated that the public use test is equivalent to the substantive due process test, $A$ could argue that the taking was not for a public use and should be enjoined. See supra note 32 .

487. This assumes that the case did not present a disproportionate punishment issue. See supra note 486.

488. Or if $A$ and others were rcquired to perform military service without receiving fair market value for their labor, no taking would occur despite the unusually serious character of the miposition. This can be explained by saying that $A$ and others are regarded as having a moral obligation to serve their country in this manner without being paid the full fair market value of their services. See supra text accompanying notes 345-70 (discussing civic obligations). 
sion" is involved. In our society, it generally is not considered wrong of a landowner to exclude third parties from her land. ${ }^{489}$ Thus, the Court is likely to find a taking when the government authorizes such a physical intrusion. ${ }^{490}$ Yet the government could have a moral justification for physically invading land or physically seizing or destroying an economically valuable tangible resource. For example, in both Caltex ${ }^{491}$ and Miller $v$. Schoene, ${ }^{492}$ the government destroyed the claimant's tangible resource, and yet no taking occurred, since the governinent had a plausible moral justification for doing so.

In other physical invasion cases, the government does not even purport to have a moral justification for depriving the claimant of her property. It simply takes physical action knowing that it will prevent the clainant from using her land in a certain manner. In Pumpelly v. Green Bay Co., ${ }^{493}$ for example, the government flooded the claimant's land, and in Causby ${ }^{494}$ the government made frequent low flights over the claimants' land. In such cases, a taking does not occur simply because $A$ 's land (or airspace) has been physically invaded. Rather, a taking occurs because the government intentionally deprives $A$ of her property by preventing $A$ from using her land for certain economically valuable purposes, and the government is not preventing or punishing wrongdoing by $A^{495}$

The second (conflicting) theme that appears frequently in the Court's takings decisions is that it is necessary to consider the government's justification for depriving $A$ of her property to determine whether a taking occurred. At times, when the Court addresses the issue of justification, it suggests that a taking occurs if the government is not seeking to promote the common good. For example, in Keystone, ${ }^{496}$ the Court explained that a taking occurred in Pennsylvania Coal Co. v. Mahon ${ }^{497}$ because the Kohler Act had been enacted for purely private benefit. ${ }^{498}$

489. See supra text accompanying note 212.

490. See, e.g., Nollan v. California Coastal Comm'n, 483 U.S. 825 (1987); Kaiser Aetna v. United States, 444 U.S. 164 (1979).

491. 344 U.S. 149 (1952).

492. 276 U.S. 272 (1928).

493. 80 U.S. (13 Wall.) 166 (1871).

494. 328 U.S. 256 (1946).

495. See the discussion of these "physical action" cases at supra text accompanying notes 109-

$11,127-49$, and 196.

496. 480 U.S. 470 (1987).

497. 260 U.S. 393 (1922).

498. Keystone, 480 U.S. at 481-84. Keystone is discussed at supra text accompanying notes $207-$ 09 and 419-23.

Moreover, the Court at times has interpreted the first part of the Agins test as equivalent to the minimum rationality standard. See Peterson I, supra note 4, at 1328-29. Under the Agins test, a taking occurs if a land-use regulation either (1) does not substantially advance legitimate state interests, or (2) denies an owner all economically viable use of his land. If the first part of the Agins 
The Court has also stated that it is less likely to find a taking when the challenged governmental action "arises from some public program [that] adjust[s] the benefits and burdens of economic life to promote the common good." 499

Again, the Court's reasoning does not explaim the cases. Surely one cannot explain the takings cases by saying that the issue is whether the government is seeking to proinote the common good. ${ }^{500}$ When the governinent formally exercises its power of emment doinain and condenins $A$ 's land for a post office, the government is taking property for a public use, and thus is seeking to promote the common good, yet it must pay just compensation. Similarly, when the government sought to obtain beach access to benefit the public in Nollan, ${ }^{501}$ the taking would have promoted the common good, yet the Court held that just compensation was due. ${ }^{502}$ The issue is not whether the government's action will promote the coinmon good, but rather whether the government is forcing $A$ to give up her property in order to prevent or pumsh wrongdoing by $A$. It is true that a justification based on a judgment of wrongdomg will be lacking in the rare case where the government is not seeking to promote the common good, but rather is seeking to promote purely private ends. But in most cases the government will be seeking to promote the common good, and the critical inquiry will be whether the governmental decisionınakers reasonably believed they were preventing or pumishing wrongdoing by $A$.

The closest the Court has come to asking whether the government liad such a inoral justification for depriving $A$ of leer property is the "noxious use" test. In Mugler, ${ }^{503}$ for example, the Court stated that "[a] prohibition simply upon the use of property for purposes that are declared, by valid legislation, to be injurious to the health, morals or safety of the community, cannot, in any just sense, be deemed a taking or an appropriation of property for the public benefit." ${ }^{\text {504 }}$ Moreover, the Court cliarac-

test simply asks whether the challenged law furthers a legitimate public purpose, then a taking would occur under this test if the government was not seeking to promote the common good when it enacted a land-use regulation.

499. Penn Cent. Transp. Co. v. New York City, 438 U.S. 104, 124 (1978). Similarly, in Connolly v. Pension Benefit Guaranty Corp., 475 U.S. 211 (1986), one reason the Court offered for finding that the withdrawal liability provisions of the MPPAA did not effect a taking was that "[t]his interference with the property rights of an employer arises from a public program that adjusts the benefits and burdens of economic life to promote the common good." Id. at 225.

500. See supra text accompanying notes 153-54, 441-42 \& 462-64.

501. 483 U.S. 825 (1987).

502. The Court stated at the close of the Nollan opinion: "California is free to advance its 'comprehensive program' [of obtaining public beach access] . . . by using its power of eminent domain for this 'public purpose' . . . but if it wants an easement across the Nollans' property, it must pay for it." Id. at 841-42.

503. 123 U.S. 623 (1887).

504. Id. at 668-69. 
terized a noxious use as wrongful, relying on "the fundamental principle that every one shall so use his own [property] as not to wrong and injure another," "505 and stating that in the case of a nuisance, "unoffending property is [not being] taken away from an innocent owner."506 Similarly, in Village of Euclid v. Ambler Realty Co., ${ }^{507}$ the Court relied on the law of nuisance and the principle that one must use one's own property in such a manner that one does not injure the property of another. 508 The Court spoke of "bad" and "good" land uses, and considered whether the ordinance was excluding land uses of "an innocent character."509 In more recent years, however, the Court has at times rejected the noxious use test ${ }^{510}$ and currently is not entirely comfortable relying on it. The Court in Keystone, ${ }^{511}$ for example, cited the noxious use cases, but did not rest its decision solely on the ground that the Subsidence Act prohibited nuisance-like conduct. ${ }^{512}$ In First English Evangelical Lutheran Church v. County of Los Angeles, ${ }^{513}$ however, the Court rehed on the noxious use cases, stating that even if the challenged flood control ordmance demed the claimant all economically viable use of his land, it would not necessarily effect a taking, since the local government had enacted the ordinance for safety reasons. ${ }^{514}$

505. Id. at 667 (quoting Fertilizing Co. v. Hyde Park, 97 U.S. 659, 667 (1878)).

506. Id. at 669 .

507. 272 U.S. 365 (1926).

508. Id. at 387.

509. Id. at 389. In Village of Euclid, the Court justified the exclusion of industrial, coinunercial, and high-density residential uses from a low-density residential area by finding that the excluded uses were similar to nuisances. Id. at 390-95.

510. See Penn Cent. Transp. Co. v. New York City, 438 U.S. 104, 133 n.30 (1978); see also supra text accoinpanying notes 390-92.

511. 480 U.S. 470 (1987).

512. See Peterson I, supra note 4, at 1318-19, 1329-30; supra text accoinpanying note 421 (discussing Keystone and the noxious use cases).

One concern the Court might have about the noxious use test is that, if interpreted narrowly, it would not account for the results in nany of the Court's takings decisions. Yet, as shown in this Article, the notion of wrongdoing that underlies the noxious use test could be expressed in terms that encompass a broad range of cases. That is, the Court could inquire whether the government is depriving $A$ of her property to prevent or punish conduct by $A$ that the governmental decisionmakers reasonably believed the public would consider wrongful. If a judgment of "wrongdoing" need not involve a strong judgment of condeinnation, and if substantial deference is given to the governmental decisionmakers' assessment of what the public would consider wrongful, no taking will be found in a wide range of cases.

513. 482 U.S. 304 (1987).

514. Id. at 313. The challenged ordinance prohibiting construction in the floodplain had been adopted as an interim measure "for the inmediate preservation of the public health and safety," after a forest fire had denuded the hills upstream froin the claimant's land, creating a serious flood hazard. Id. at 307. Justice Stevens commented that "[i]n light of the tragic flood and the loss of life that precipitated the safety regulations here, it is hard to understand how [the claimant] ever expected to rebuild on Lutherglen." Id. at 327-28 (Stevens, J., dissenting). On remand, the California Court of Appeal concluded that the interim ordinance did not effect a taking, relying primarily on the fact that the ordinance was designed to protect the public health and safety. First 
The final theme that arises frequently in the Court's takings decisions is that a significant factor in determining whether a taking occurred is whether the claimant reasonably relied to her economic detriment on an expectation that the government would not act as it did. The Court usually discnsses this rehance factor in the context of the Penn Central test, which asks whether the government interfered with the claimant's "reasonable, investment-backed expectations." 515 If, in fact, the critical issue is whether the government had a moral justification for requiring the claimant to give up her property, the Court has placed too inuch emphasis on reliance. Generally, whether it would be wrong of $A$ not to give up her property does not depend upon whether she has rehed on the government not requiring lier to do so.

Consider, for example, a case in which the government warns $A$ that it intends to require lier to give up certain property, and $A$ therefore does not rely to her economic detriment on an expectation that the government will not deprive her of that property. If such rehance were a prerequisite to establishing a taking, as Monsanto ${ }^{516}$ suggests, ${ }^{517}$ then no taking would occur when the government acted in accordance with its warning. Yet in Nollan ${ }^{518}$ the Court found a taking despite the government's announceinent of its intentions. ${ }^{519}$ The fact that the government previously warned $A$ that it planned to deprive ler of her property does not establish that it is wrong of $A$ not to give up her property without receiving just compensation..$^{520}$

Conversely, the fact that $A$ relied on a reasonable expectation that the government would not require her to give up certain property does not establish that the government is not preventing wrongdoing when it later deprives $A$ of that property. In Mugler, ${ }^{521}$ for example, the claimant invested in rehance on an expectation that the inanufacture of beer would not be prohibited; in Hadacheck v. Sebastian, ${ }^{522}$ the claimant invested in rehance on an expectation that he could continue to operate a

English Evangelical Lutheran Church v. County of Los Angeles, $210 \mathrm{Cal}$. App. 3d 1393, $258 \mathrm{Cal}$. Rptr. 893 (1989).

515. See Peterson I, supra note 4, at 1320-25.

516. 467 U.S. 986 (1984).

517. See Peterson I, supra note 4, at 1324.

518. 483 U.S. 825 (1987).

519. If such reliance were not a prerequisite, but simply one factor to consider, then this factor would have weighed against finding a taking in Nollan. Yet in the Court's view it simply was not relevant. See Peterson I, supra note 4, at 1338, 1340-41.

520. The phrase "reasonable, investment-backed expectations" came from Michelman's article, Property, Utility and Fairness: Comments on the Ethical Foundations of 'Just Compensation' Law, supra note 164. There Michelman asserted that "a prior warning of possible collective action ... obviates any need for compensation when such action materializes." Id. at 1239. Thus, Michelman apparently would disagree with the decision in Nollan.

521. 123 U.S. 623 (1887).

522. 239 U.S. 394 (1915). As discussed at supra note 221, Michelman concluded that 
brickyard in that location; and in Caltex, ${ }^{523}$ the claimants invested in reliance on an expectation that the governinent would not destroy their oil facilities. If reliance were critical, one would think that in eacli case a taking would have occurred, yet in eacli case the Court found no taking.

In inost instances, the fact that $A$ reasonably relied on an expectation that the government would not force lier to give up certain property relates rather indirectly to whether $A$ 's present conduct is considered blameworthy. Consider a case in which the "property" at issue is $A$ 's freedoin to use a parcel of land in a particular manner. If at Tine 1 , $A$ "reasonably" relied on an expectation that she could continue to use the land to do $\mathrm{X}$, then presuinably at Time 1 it was not considered wrongful to do $\mathrm{X}$ on the land and it did not appear likely that sucli conduct would be regarded as wrongful in the future. If at Time 2, such conduct is judged to be wrongful, then either that judgment of wrongdoing is unreasonable or circuinstances have changed. Perhaps factual circunstances have clianged (as they did in Hadacheck and Caltex). Perhaps public values have changed (as they did in Mugler). But if circumstances have not changed, then $A$ 's "reasonable reliance" at Time 1 suggests that the judgment of wrongdoing at Tine 2 is unreasonable.

$A$ 's reliance is more directly relevant to the inoral assessment of $A$ 's behavior when the government induced that reliance by promising $A$ it would not deprive her of certain property. In such a case, one factor supporting the view that it is not wrong of $A$ not to give up her property is that the government induced $A$ to rely to her economic detriment on the government keeping its promise. ${ }^{525}$ In Lynch, ${ }^{526}$ for example, one could argue that one reason the government was not morally justified in

Hadacheck was wrongly decided, since the brickyard owner's expectations had "crystallized" before those of the neighboring landowners. Michelman, supra note 164, at 1237, 1242.

523. 344 U.S. 149 (1952).

524. $A$ 's past reliance could be relevant to a judgment of wrongdoing in other ways as well. For example, assume (as in Hadacheck) that $A$ invested her money and labor in establishing an industrial use in a particular location, reasonably relying on an expectation that the law would continue to permit that use in that location. At the time, there were no surrounding conflicting land uses and none were reasonably foreseeable. Later, however, residential uses surrounded $A$ 's industrial use, and a law was enacted prohibiting all industrial uses in the area, including previously established industrial uses. The fact that $A$ reasonably relied in the past relates to whether $A$ 's conduct is now considered blameworthy in at least two ways. First, in this case $A$ relied by establishing her industrial use before residential uses were established in the vicinity. Therefore, $A$ can argue that one reason she should not be considered the wrongdoer in this conflict is that she was there first. As discussed above, see supra text accompanying note 221, the fact that Hadacheck was there first made Hadacheck a more difficult case, although other factors supported the judgment that Hadacheck was the wrongdoer. In addition, the fact that $A$ 's reliance was "reasonable" when she first established her industrial use means that $A$ 's conduct was not considered wrongful at that time, which may cast doubt on whether $A$ 's conduct is now considered blameworthy. As discussed above, such doubts might be removed by showing that factual cireumstances changed or that public values changed.

525. See supra text accompanying note 326 (discussing governmental promise cases).

526. 292 U.S. 571 (1934). 
requiring the veterans to give up their vested rights under the War Risk Insurance Act was that many veterans had relied on the government's promise to insure them by not purchasing death and disability insurance from other sources. ${ }^{527}$

Yet even in governmental promise cases, the ultimate issue is not whether $A$ rehed on the government fulfilling its promise. The issue is whether it is wrong of $A$ not to give up ler vested rights without receiving colnpensation. ${ }^{528}$ Even if $A$ has not rehed, it may not be wrong of $A$ not to give up her property. For example, suppose the government granted $A$ vested rights to certain land. ${ }^{529}$ If the government subsequently enacted a law requiring $A$ to transfer her rights to the land to the government, and the lawmakers did not reasonably believe the public would consider it wrong of $A$ not to do so, then a taking would occur even if $A$ had not yet relied to her economic detriment on an expectation that the government would not deprive her of this property.

Conversely, even if $A$ has detrimentally relied on a governmental promise not to take certain property, it could be wrong of $A$ not to give up that property. For example, if the government granted $A$ a vested right to conduct a certain business, sucl as a lottery, for a certain number of years, and the public later came to view that business as immoral, the lawmakers might reasonably conclude that the public would consider it wrong of $A$ not to give up her vested right to operate the lottery. 530

Thus, when the Court suggests that a key issue in determining whetlier a taking occurred is whether the claimant relied to lier economic detriment on a reasonable expectation that the government would not force her to give up the property, the Court is focusing on the wrong question. The ultimate issue is whether the lawinakers reasonably believed that they were preventing or punishing blameworthy bellavior by $A$. There is only an indirect relationship between that issue and the issue of reliance.

\section{CONCLUSION}

This Article has slown that despite the doctrinal chaos, there is a pattern to the Court's takings decisions. That pattern is not attributable

527. As discussed at supra text accompanying notes 197-200, Congress did not even purport to be preventing wrongdoing when it enacted the statute challenged in Lynch. However, if it had, one factor to consider in assessiug the reasonableness of Congress' judgment of wrongdoing would have been the fact that many to whom the statute applied had already relied on the government's promise.

528. See supra text accompanying notes 303-31 (discussing governmental promise cases).

529. That is, the government transferred its claim to the land to $A$, thereby making a commitment that $A$ would be regarded as having a superior moral claim to that land.

530. See supra text accompanying notes 333-35 (discussing Stone v. Mississippi, 101 U.S. 814 (1880)). 
to the announced doctrine, but rather to the fact that the Justices evidently are deciding these cases according to their sense of when it is fair for the government to take something of economic value from a private party without paying for it. By following their noral intuitions, they have produced results that can be explained in a coherent manner.

The Justices appear to be following the intuition that fairness does not require that compensation be paid if the government is simply stopping the claimant from doing something wrong, or if she is being punished for domg something wrong. But if the government is forcing a private party to give up her property and is not preventing or punishing wrongdoing, then the government is simply taking her property to benefit others, and she should be paid for it. Although the borderline takings cases are difficult, the principles underlying the takings decisions are surprisingly straightforward. 